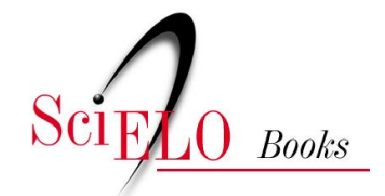

\title{
Sociedade industrial no Brasil
}

\author{
Juarez Rubens Brandão Lopes
}

LOPES, JRB. Sociedade industrial no Brasil [online]. Rio de Janeiro: Centro Edelstein de Pesquisas Sociais, 2008, 168p. ISBN: 978-85-9966-277-9. Available from SciELO Books $<$ http://books.scielo.org $>$.

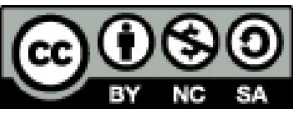

All the contents of this chapter, except where otherwise noted, is licensed under a Creative Commons Attribution-Non Commercial-ShareAlike 3.0 Unported.

Todo o conteúdo deste capítulo, exceto quando houver ressalva, é publicado sob a licença Creative Commons Atribuição Uso Não Comercial - Partilha nos Mesmos Termos 3.0 Não adaptada.

Todo el contenido de este capítulo, excepto donde se indique lo contrario, está bajo licencia de la licencia Creative Commons Reconocimento-NoComercial-CompartirIgual 3.0 Unported. 


\section{Biblioteca Virtual de Ciências Humanas}

\section{SOCIEDADE INDUSTRIAL NO BRASIL}

\section{Juarez Rubens Brandão Lopes}




\section{Juarez Rubens Brandão Lopes}

\section{Sociedade Industrial no Brasil}

Esta publicação é parte da Biblioteca Virtual de Ciências Humanas do Centro Edelstein de Pesquisas Sociais - www.bvce.org

Copyright () 2008, Juarez Rubens Brandão Lopes

Copyright (c) 2008 desta edição on-line: Centro Edelstein de Pesquisas Sociais

Nenhuma parte desta publicação pode ser reproduzida ou transmitida por qualquer meio de comunicação para uso comercial sem a permissão escrita dos

proprietários dos direitos autorais. A publicação ou partes dela podem ser

reproduzidas para propósito não-comercial na medida em que a origem da publicação, assim como seus autores, seja reconhecida.

ISBN 978-85-99662-77-9

Centro Edelstein de Pesquisas Sociais

www.centroedelstein.org.br

Rua Visconde de Pirajá, 330/1205

Ipanema - Rio de Janeiro - RJ

CEP: 22410-000. Brasil

centro edelstein de pesquisas sociais

Contato: bvce@centroedelstein.org.br 
Sumário

Prefácio .1

Introdução: sociologia industrial e desenvolvimento econômico 8

Capítulo I

$O$ ajustamento do trabalhador à indústria: mobilidade social e motivação.

1. Colocação do problema

2. A fixação do operário de origem rural na indústria .22

3. A solidariedade grupal e a produtividade do operário semiqualificado

4. O operário qualificado e sua motivação no trabalho .735

5. Conclusão

\section{Capítulo II}

Informação e organização: estudo de uma empresa industrial

1. Introdução

2. Aspectos da organização e da administração da fábrica...

3. O sistema de comunicações na fábrica

4. Conclusão

\section{Capítulo III}

A motivação do trabalho: observações sobre a restrição de produção .1233

1. A restrição de produção entre operários dos países desenvolvidos....123

2. Observações sobre a produção do operário numa fábrica brasileira; desenvolvimento econômico e restrição de produção

\section{Capítulo IV}

Relações industriais em duas comunidades brasileiras

1. Introdução

2. As relações industriais ........................................................... 135

3. O papel do sindicato ............................................................... 141

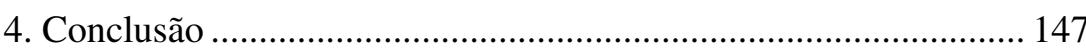

Capítulo V

Sistema industrial e estratificação social

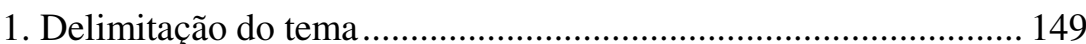

2. Conceituação ........................................................................ 149

3. Influência das mudanças recentes do sistema industrial na estratificação da sociedade ocidental

4. Algumas observações sobre industrialização e estratificação social no Brasil 


\section{Prefácio}

Os estudos sociológicos reunidos neste volume pelo Prof. Juarez Rubens Brandão Lopes, da Universidade de São Paulo, representam uma valiosa contribuição à inteligência do processo de industrialização na sociedade brasileira contemporânea. Representam, por vários aspectos, um trabalho pioneiro que, por suas marcadas e amadurecidas diretrizes metodológicas, está destinada a influenciar decisivamente as futuras indagações nesse campo. Como poucas vezes se tem logrado entre nós nas pesquisas de ciências sociais, o autor consegue um equilíbrio e acerto felizes. Entre uma ampla interpretação sociológica e a precisão e minúcia dos dados coletados, na sua grande maioria, diretamente.

Não seria sem propósito apontar a posição metodológica assumida pelo autor como responsável, em boa parte, pelo mérito da contribuição ora apresentada. Desta posição metodológica há alguns traços que aqui desejaríamos destacar.

Ao buscar a base empírica de suas análises, o autor se entrega a uma coleta direta e extensa de dados, servindo-se, em grande parte, da técnica da entrevista livre. A variedade e as minúcias de aspectos da realidade estudada, bem como as sugestões e hipóteses para novas indagações, que brotam das entrevistas, - aqui muitas vezes transcritas literalmente constituem por si só uma fascinante revelação de um setor de nossa vida social ainda pouca conhecido, como o é o das relações trabalhistas. No entanto, o peso mesmo dessa documentação de natureza pessoal tenderia a exigir uma interpretação em que os traços individuais e subjetivos dominassem sobre a visão global e objetiva da realidade social estudada. Isto, porém, não ocorre porque o autor adota, de antemão, um esquema ou método interpretativo de caráter global e estrutural. Esse modelo, ele o empresta de Max Weber e, de modo mais preciso, à análise weberiana da estrutura social em termos de classe, status e poder ${ }^{1}$.

Não deixa porém de criar dificuldades especiais a adoção da técnica da entrevista livre como instrumento principal de coleta dos dados que

${ }^{1}$ From Max Weber: Essays in Sociology, translated, edited, and with introduction by H. H. Gerth and C. Wright Mills, Nova Iorque, Oxford University Press, 1946. deverão servir à interpretação estruturalista do modelo weberiano ${ }^{2}$. O autor esbarra frequentemente com tais dificuldades, saindo-se delas, não raro, de maneira feliz, com refinamentos originais de análise dos dados. Outras vezes, no entanto, teve que apelar para dados de outra natureza, ainda que essa complementação assuma, no contexto geral, uma função secundária ou de arrimo.

Resulta dessa posição metodológica do autor que se torna arriscado apreciar as características globais de suas pesquisas, ou seja, a maneira como se fez a aplicação do esquema interpretativo estruturalista às relações trabalhistas brasileiras, sem que se cometa a injustiça de deixar de lado a riqueza mesmo de informações, interpretações e hipóteses laterais que estão de entremeio ou expressamente sugeridas na apresentação do material das entrevistas livres. No entanto, ainda, correndo o risco de cometer essa injustiça, tentaremos analisar os traços mais gerais dos presentes estudos.

O tema maior de indagação é o processo ou dinâmica da industrialização na sociedade brasileira. A industrialização não é concebida, de modo estreito e limitado, como o aumento do número de fábricas. Empresta-se ao processo uma inteligência mais ampla e sociológica, segundo uma orientação que vem já de Augusto Comte ${ }^{3}$. Seria possível ir além e reconhecer nos presentes estudos uma abordagem do industrialismo, dada a este termo a acepção que lhe atribui o grupo de economistas e

${ }^{2}$ Em dificuldades semelhantes encontrou-se William Lloyd Warner, em seus esforços por traçar a estrutura de classes na sociedade norte-americana atual, a partir, em grande parte, dos dados colhidos, também, através da técnica da entrevista livre. Cf. especialmente, The social system of the modern factory, New Haven, Yale University Press, 1947, and The status system of a modern community, New Haven, Yale University Press, 1950.

3 "Comte não define a sociedade industrial pela indústria; para ele, não é a criação de grandes fábricas ou as concentrações industriais o que caracteriza essa sociedade, e sim, são seus traços essenciais os seguintes: primeiro, a liberdade de trabalho para os indivíduos. Os trabalhadores estão livres e não amarrados por uma condição hereditária ou condenados a permanecer aonde por acaso tenham nascido. Segundo, a posição de cada um na sociedade é determinada, fundamentalmente, pela função que desempenhe no quadro total ou coletivo de trabalho. A hierarquia e os valores são estabelecidos por essa organização funcional do trabalho e da sociedade. Finalmente, o trabalho se transforma com a aplicação sistemática da ciência à organização da produção" (Raymond Aron, "The concept of industrial society" in World technology and human destiny, Ann Arbor, The University of Michigan Press, 1963, p. 59). 
sociólogos norte-americanos, interessados nos estudos internacionais ou comparativos de sociologia industrial, com Kerr, Harbison e outros à frente ${ }^{4}$.

Razões de especialização levam a que se considere à parte uma sociologia industrial, a qual, porém, não poderia se limitar ao estudo das "relações humanas do trabalho", tal como se pretendeu a princípio, com os trabalhos de Elton Mayo e seus colaboradores, cuja influência no desenvolvimento da sociologia industrial é hoje por todos reconhecida ${ }^{5}$. Como tantas vezes insiste o autor, a sociologia industrial tem que considerar a sociedade toda em que se desenrolam as relações trabalhistas.

Nesse caso, é fundamental para compreensão da posição metodológica do autor saber onde se situou entre as várias abordagens, das mais genéricas às mais específicas, adotadas pelos modernos estudos do industrialismo ou da industrialização.

O industrialismo (conceito histórico-cultural ou antropológico) ou a industrialização (conceito estrutural ou sociológico) são apontados, por vezes, como marca fundamental da etapa histórica das sociedades atuais, das mais avançadas às mais atrasadas, economicamente falando-se. Aquelas e estas sociedades vivem sob o impacto do processo de industrialização ou do ethos ou padrão cultural do industrialismo. A compreensão deste ethos ou daquele processo de transformação seria, pois, fundamental para a compreensão do mundo moderno, seja em termos de desenvolvimento de cada nação, seja em termos das relações entre as nações e do destino da civilização e do homem contemporâneos.

Tal e tão amplíssima concepção do processo da industrialização e do industrialismo, vamos encontrá-la formulada por Raymond Aron. Porque a industrialização se desenvolveu primeiro na Europa Ocidental e nos Estados Unidos, esta concepção facilmente se confunde com o processo de ocidentalização do mundo moderno. É como se aceitasse, sem mais ampla análise, que todas as nações adotaram ou deverão adotar o padrão da

4 Ver: "O estudo inter-universitário dos problemas laborais relacionados com o desenvolvimento econômico" in Clark Kerr, John T. Dunlop, Frederick H. Harbison e Charles A. Myers, Industrialismo e sociedade industrial, Rio de Janeiro, Fundo de Cultura, 1963.

5 "La sociologie industrielle", Current Sociology, vol. XII, n. 2, 1963-64. sociedade industrial ocidental, apesar das meramente aparentes resistências apresentadas, inclusive a União Soviética, a Índia, os países africanos. A análise de economistas como Colin Clark $^{6}$ e Rostow $^{7}$, e as dos já mencionados sociólogos industriais norte-americanos, só são possíveis, como o observa Aron ${ }^{8}$, "porque aceitam que todas as sociedades atuais pertencem ao mesmo tipo social; todas elas se desenvolvendo na mesma linha, forçando as mesmas normas de progresso ou de modernização" 9 .

Esta concepção larga foi adotada pelo Congresso da Liberdade da Cultura, quando tomou para tema de várias de suas reuniões e estudos o binômio "Tradição e Mudança". O que levou a pôr juntos os elementos desse binômio foi a idéia de que todas as sociedades - é Aron que escreve "tanto aquelas que chamamos desenvolvidas como aquelas apontadas como subdesenvolvidas, estão atualmente experimentando um conflito entre suas tradições e as mudanças rápidas que o crescimento traz... Se o choque entre tradição e modernismo é mais violento nos países subdesenvolvidos, ele também ocorre nas chamadas sociedades do Ocidente" ${ }^{10}$.

O tema destes estudos do Prof. Juarez Brandão Lopes é também o da "tradição e mudança", ou seja, da transição do tradicionalismo ao modernismo. Todavia, o que entende ele por tradicionalismo ou por organização social tradicional é mais limitado e mais específico, o que lhe permite, desde logo, separar a interrogante das sociedades desenvolvidas até aonde poderão continuar a desenvolver-se? - da interrogante das sociedades subdesenvolvidas - com que sacrifícios dos seus valores humanos, culturais e políticos obterão o desenvolvimento?

Os estudos dos antropólogos do fim do século passado, que seguiram a senda da expansão do colonialismo na Ásia e na Oceania, denunciavam em cores dramáticas o desmantelo cultural resultante do encontro cultural e político entre o Ocidente e o Oriente. Contribuíram esses estudos para que

${ }^{6}$ Colin Clark, The Conditions of economic progress, 3rd. ed., Londres, Macmillan, 1957.

${ }^{7}$ Walt W. Rostow, Etapas do desenvolvimento economico: um manifesto não-comunista, Rio de Janeiro, Zahar, 1961.

${ }^{8}$ Raymond Aron, ed. World technology and human destiny, Ann Arbor, The University of Michigan Press, 1963. (trad. de Colloques de Rheinfelden, Paris, 1960).

${ }^{9}$ Op. cit., p. 58.

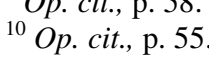


as análises do processo da industrialização, do princípio deste século, viessem marcadas também por esta nota de destaque da demolição da sociedade tradicional. Em artigo recente, Herbert Blumer ${ }^{11}$ ainda não abandona de todo essa concepção da industrialização quando a defende de acusações exageradas quanto aos seus efeitos dissolventes. Ao mesmo tempo, na segunda parte desse artigo, avança o que se poderia considerar a concepção hoje predominante, de que a industrialização deve ser entendida, não como um processo de fora para dentro, imposto mecânica ou "autoritariamente", e sim, de dentro para fora, orgânico ou "democrático". Blumer indica cinco maneiras das sociedades responderem à industrialização, maneiras estas que não só facultam este processo, como lhe dão as características diversas que assume ele em cada sociedade: a resposta da rejeição, a disjuntiva, a assimilativa, a de reforçamento e a dissolvente.

O Prof. Juarez Brandão Lopes se coloca, claramente, dentro da concepção moderna de uma compreensão orgânica do processo de industrialização. Não se preocupa, porém, nem com as "elites industrializantes" 12 , nem com as orientações globais de receptividade ou resistência à industrialização, tais como as apontadas por Blumer. Deixa implícito ou pacífico o esforço das elites industrializantes e passa a considerar as resistências de modo mais específico e detalhado. Analisa os esforços de adaptação da sociedade tradicional, ou melhor dos trabalhadores rurais, à nova sociedade industrial e de modo mais direto, às fábricas. Do binômio tradicionalismo-modernismo, sua atenção é antes sobre o tradicionalismo ou elementos da estrutura tradicionalista de poder. Em raros casos, efetivamente, analisa a nova ordem social. O papel dos patrões ou industriais fica, assim, limitado quanto aos seus esforços de contemporização ou manipulação dos padrões sociais tradicionais.

Por certo, a ênfase que o Prof. Juarez Brandão Lopes dá ao processo de transformação da sociedade tradicional ou da sua subsistência nas relações trabalhistas, não resulta de um ponto de vista a priori, e sim, da justa e correta análise dos dados, ou seja, das duas situações de trabalho que

11 Herbert Blumer, "Industrialization and the traditional order", Sociology and Social Research, January, 1964, p. 129-138.

12 (12) Clark Kerr, John T. Dunlop, Frederick H. Harbison, Industrialismo e a sociedade industrial, Rio de Janeiro, Fundo de Cultura, 1963. tomou para objeto de seus estudos, uma no interior e outra na capital do Estado de São Paulo.

Destacando, por razões de ordem empírica, o processo de transformação ou de contemporização da sociedade tradicional, o autor não chega, porém, a enunciar, de modo mais expresso, o seu conceito de sociedade tradicional. Refere-se especificamente à sociedade tradicional brasileira. Não, propriamente, a sociedade correspondente à época e local das pesquisas, e sim, àquela em que cresceram ou em última análise têm sua origem os trabalhadores entrevistados quase todos eles de procedência rural. A menor atenção que dá à diferença que vai entre um trabalhador rural recém-emigrado do campo e um outro que ao campo se prende somente por sua ascendência - o que leva a subestimar os processos de urbanização e das transformações familiares - torna difícil reconhecer até que ponto a continuidade da sociedade tradicional está sendo entendida em termos estruturais ou históricos. Por outras palavras, o trabalhador que predomina nas fábricas é rural, em parte, porque conserva, por tradição histórica, valores e padrões próprios do campo, mas o é, fundamentalmente, porque a sua dependência para com os patrões e suas relações para com estes continuam a ser as mesmas que existem ou existiam no meio rural. Sente-se que esse conceito de tradicionalismo deveria ser mais elaborado. Talvez, um passo nesse sentido seria verificar, em que medida corresponde efetivamente à nossa realidade a distinção entre um tradicionalismo histórico ou "clássico mediterrâneo" e um tradicionalismo estrutural ou "urbano contemporâneo", preconizada por Silvert ${ }^{13}$ precisamente para o estudo das sociedades latino americanas. A simples referência à sociedade tradicional tal como a define Max Weber pouco esclarece. Rotula-se uma realidade que, na verdade, não se reconhece. Mesmo porque é sabido que a sociedade tradicional weberiana tem pontos essenciais de diferença com o meio rural brasileiro destes últimos anos em que, para mencionar um só traço diferenciador, a moeda e o mercado já estão razoavelmente introduzidos.

${ }^{13}$ K. H. Silvert,. "Les valeurs nationales, le développement, les leaders et leurs troupes", Revue Internationale des Scíences Sociales, v. XV, n. 4, 1963 (Sociologie du Développement en Amérique Latine), p. 594-605. 
Esboçado assim o quadro maior de cogitações sobre a moderna sociedade industrial, a que se prendem os estudos ora reunidos neste volume pelo Prof. Juarez Brandão Lopes, é necessário voltar a insistir em que a contribuição pioneira e marcante que trazem eles ao conhecimento das relações industriais no Brasil e à análise das transformações de uma sociedade tradicionalista, se fundamenta em uma cuidadosa e direta coleta de dados, orientada por uma posição metodológica esclarecida e ampla.

São Paulo, julho de 1964 Mario Wagner Vieira da Cunha Professor (ap) da Universidade de São Paulo

\section{Introdução: sociologia industrial e desenvolvimento econômico}

As interrelações da ciência social com a sociedade são múltiplas e sutis. A sociologia industrial, que se desenvolveu neste século nos países economicamente adiantados, mormente nos Estados Unidos, formula problemas e apresenta respostas, que correspondem à realidade imediata de que trata, sendo mais especificamente válidos para tais países ${ }^{1}$. Assim, somente nos últimos anos, principalmente devido a uma crescente preocupação naqueles países com o "terceiro mundo", é que aí surgiram formulações de problemas e estudos com maior relevância às sociedades em vias de desenvolvimento.

Realizaram-se nos Estados Unidos, a partir do segundo quartel deste século, estudos de caráter empírico e objetivos práticos sobre grupos de trabalhadores, considerados por muitos como o início da sociologia industrial moderna desses trabalhos merecem destaque, pela influência que exerceram e ainda exercem, aqueles feitos na fábrica Hawthorne em Chicago, sob a orientação de Elton $\mathrm{Mayo}^{2}$. $\mathrm{Na}$ série de pesquisas

${ }^{1}$ Não queremos dizer que deste condicionamento das ciências sociais pela estrutura socia resulte sempre uma problemática adequada ao que é importante na sociedade em questão. Pelo contrário, parece-nos claro que a problemática que surge, tanto o que é colocado como problema como o que é ignorado, precisa para ser compreendida de ser vista na sua fundamentação social. A análise penetrante de Arthur K. Davis, por exemplo, mostra as determinantes sociais do alheamento da sociologia americana dos problemas de real importância na sociedade, assim como da separação entre, de um lado, a teoria sociológica de natureza estática, abstrata, não histórica (juntamente com trabalhos quantitativos minuciosos de pequenos grupos e outros que tais) e, do outro lado, o estudo de problemas sociais marcado pela superabundância de dados empíricos e pelo baixo nível de generalização. Uma coisa e outra, reforçadas pelas éticas que Davis denomina de "neutralidade" e de "ciência não ideológica" dos cientistas sociais, contribuem "para a estabilidade da ordem social existente". Arthur K. Davis, "Social Theory and Social Problems: Fragments for a Philosophy of Social Science", Philosophy and Phenomenological Research, vol. XVIII, n. 2 (dezembro de 1957), p. 190-208.

${ }^{2} \mathrm{O}$ primeiro relato desses trabalhos foi feito por Mayo em The Human Problems of an Industrial Civilization, Nova Iorque: Macmillan Co., 1933. Os resultados completos das pesquisas da Hawthome (Western Electric) acham-se descritos em F. J. Roethlisberger e W. J. Dickson, Management and the Worker, Cambridge: Harvard University Press, 1939 e T. 
conduzidas naquele estabelecimento, passou-se de uma perspectiva em que, para a compreensão do comportamento no trabalho (e em especial da produtividade), enfocavam-se tão-somente o indivíduo e as condições físicas de trabalho (a duração do esforço físico, a iluminação etc.), para outra, na qual o centro de interesse era o grupo e se emprestava particular relevo às atitudes do trabalhador para com a própria tarefa, a mestria e a empresa. Desenvolveu-se, com esse e outros estudos, uma orientação que veio a ser conhecida como escola ou perspectiva das "relações humanas no trabalho". Ela se caracteriza pelo interesse na "organização informal": a estrutura e funcionamento dos grupos surgidos espontaneamente durante $o$ trabalho, as suas bases, as normas e valores que manifestam, e o seu comportamento. A visão que emerge, segundo Gouldner ${ }^{3}$, é a da empresa como "sistema natural", como um "todo" orgânico, exibindo uma estrutura não planejada, que resulta da intenção dos indivíduos que dela fazem parte. A própria mudança da estrutura da empresa é encarada como processo que ocorre naturalmente, sem relação estreita com o que é deliberado. A "organização formal", definida em contraposição à "informal", e que se expressa nos documentos oficiais da companhia (organograma, regulamento, ordens de serviço etc.) é relegada a segundo plano. Os estudiosos desse grupo deixam de lado igualmente, não merecendo a atenção e a investigação cuidadosa que dedicavam aos pequenos grupos de trabalho, os temas clássicos da sociologia industrial européia: a formação e a condição da classe operária, a estrutura e o funcionamento da organização sindical ${ }^{4}$. O interesse prático pela resolução dos "problemas" do trabalho na empresa e a preocupação com o desenvolvimento de técnicas administrativas que os sanem, tais como as referentes à chefia e ao moral da organização, ressaltavam de todas as pesquisas desse grupo ${ }^{5}$.

N. Whitehead, The Industrial Worker, 2 vols., Cambridge: Harvard University Press, 1938. ${ }^{3}$ Alvin W. Gouldner, "Organizational Analysis", Sociology Today: Problems and Prospects (org. por R. K. Merton, L. Broom e L.S. Cottrell, Jr.), Nova Iorque: Basic Books, Inc., 1959, p. 400-428.

${ }^{4}$ Cf. F. Le Play, L'Ouvriers Européens, 2 vols., Paris. 1955; Charles Booth, Life and Labour of the People of London, 18 vols., 1903; Sidney e Beatrice Webb, The History of Tradeunionism (1894) e Industrial Democracy (1897).

${ }^{5}$ Haire aponta como idéias básicas dos estudos de relações humanas e de dinâmica grupal: 1) participação, 2) nova concepção de liderança e técnicas de treinamento, e 3) padrões de comunicação. Mason Haire, "Group Dynamics in the Industrial Situation", in A. Kornhauser, R.
Na década dos 40, a abordagem das relações humanas foi submetida à cerrada crítica por parte de muitos cientistas sociais ${ }^{6}$. A controvérsia resultante influenciou, não há dúvida, o curso das investigações desde então encetadas. Ela tem para nós clara relevância na formulação de uma problemática, para os países subdesenvolvidos em processo de industrialização.

Salientaram os críticos da escola das relações humanas os seguintes pontos: 1) Os seus estudos ignoravam a organização social mais ampla em que a empresa e o grupo de trabalho se inserem. Diz-nos Friedmann, por exemplo, que a alienação do trabalhador, o seu desarraigamento e a destruição dos laços comunais, provocados pelas alterações na estrutura ocupacional durante a segunda revolução industrial estariam na raiz de muitos fenômenos observados pelos analistas dos pequenos agrupamentos de operários dentro das organizações ${ }^{7}$. 2) As suas posições ideológicas e normativas não explícitas (distorção pró-direção empresarial e a correlata ideologia da cooperação e harmonia industriais) falseavam as suas observações e conclusões. 3) Os referidos estudos apresentavam - ainda devido aos mesmos valores - flagrante indigência teórica, resumindo-se a diagnósticos de situações, que em cada caso precisavam ser repetidos, como, por exemplo, a distorção clínica de Mayo manifestada no vocabulário e nas analogias feitas com a medicina.

Pode-se concordar desde já que algumas das críticas eram exageradas e às vezes mal formuladas, não correspondendo bem ao estado da sociologia do trabalho. Assim, por exemplo, são da mesma época as pesquisas feitas

Dubin e A. M. Ross (orgs.). Industrial Conflict, Nova Iorque: McGraw-Hill, 1954, p. 373-385.

6 Ver, entre outros, C. W. Hart. "The Hawthorne Experiments", Canadian Journal of Economics and polítical Science, maio de 1943; Herbert Blumer, "Sociological Theory in Industrial Relations", American Sociological Review, vol. 12, dezembro de 1947, p. 271278; W. E. Moore. "Current Issues in Industrial Sociology," American Sociological Review, vol. 12, junho de 1947, p. 651-657; Harold L. Sheppard, "The Treatment of Unionism in Management Sociology", American Sociological Review, vol. 14, abril de 1949, p. 310-313; Reinhard Bendix e Lloyd Fisher, "The Perspectives of Elton Mayo", The Review of Economics am Statistics, vol. 31, novembro de 1949. Uma avaliação critica mais recente da escola das relações humanas é feita por Clark Kerr e Lloyd H. Fisher, "Plant Sociology: The Elite and the Aborigines", in Mirra Komarovsky (org.), Common Frontiers of the Social Sciences, Glencoe: The Free Press, 1957, p. 281-309.

7 Problèmes Humains du Machinisme Industriel, edição revista e aumentada, Paris: Gallimard, 1946. 
por W. Lloyd Warner e J. O. Low, sobre a greve em Yankee City ${ }^{8}$, e a de William F. Whyte sobre o sindicato ${ }^{9}$, pesquisas essas que contraditam as afirmações de que a abordagem das relações humanas ignoravam o conflito industrial e as transformações econômicas e sociais mais amplas. Entretanto, também não se pode negar que aqueles críticos influenciaram a sociologia do trabalho no sentido de uma melhor colocação dos problemas no contexto da sociedade global, de interesse mais freqüente pela empresa como organização, de maior elaboração teórica das investigações e, no caso da pesquisa realizada com preocupação prática, de uma formulação mais clara do ponto de vista instrumental e dos objetivos a serem atingidos ${ }^{10}$.

Atualmente as duas primeiras tendências são perfeitamente discerníveis e merecem ser destacadas. Em primeiro lugar, nos últimos quinze anos, investigações feitas nos países industriais na sociologia do trabalho utilizaram-se do conceito de Max Weber de organização burocrática e, em segundo lugar, cada vez mais estudam-se problemas nesse campo como parte da sociedade global.

Não está claro em que medida o emprego do conceito de burocracia, em trabalhos tais como os de Blau, Turner, Davis, Francis e Stone, e Gouldner $^{11}$, representa uma orientação nova de investigação, em relação aos feitos sob a perspectiva das relações humanas. As normas e a estrutura burocrática, às vezes, parecem neles ser usadas como uma das forças, ou fatores que, junto com as demais, derivadas da organização informal, nas quais concentram a atenção, ajudam a explicar o comportamento dos membros da organização. Progrediu-se além da antiga dicotomia

${ }^{8}$ The Social System of the Modern Factory, New Haven: Yale University Press, 1947. Esta pesquisa foi realizada durante a Grande Depressão, nos anos 30. Sobre as ligações de Warner com as pesquisas de Elton Mayo, ver as referências sobre o assunto em Human Problems of an Industrial Civilization, p. 122-143.

${ }_{9}^{9}$ Patterns of Industrial Peace, Nova Iorque: Harper \& Brothers, 1951

${ }^{10}$ Ver também o sumário das tendências da sociologia industrial feito por Jean-René Tréanton e Jean-Daniel Reynaud, "La Sociologie Industrielle 1951-62", La Sociologie Contemporaine, vol. XII, n. ${ }^{\text {o }}$ (1963-64), p. 123-136.

${ }^{11}$ Peter M. Blau, The Dynamics of Bureaucracy: A Study of Interpersonal Relations in two Government Agencies, Chicago: The University of Chicago Press, 1955; Roy G. Francis e Robert C. Stone, Service and Procedure in Bureaucracy: A Case Study, Minneapolis: The University of Minnesota Press, 1956; e Alvin W. Gouldner, Patterns of Industrial Bureaucracy, Londres: Routledge \& Kegan Paul, Ltd., 1955. "organização formal" e "organização informal"? Em que medida apenas se mudou o vocabulário? Se não mais, parece que pelo menos encontramos nessas pesquisas uma mudança de foco. Ao invés de uma preocupação de explicar a própria organização informal, vemos um tratamento deliberado de como essa organização influencia (reforça, modifica ou anula) a formal (ou burocrática). O que antes se relegava a segundo plano, passa a ser o que se procura explicar. Por outro lado, e é isto que devemos sublinhar nesses estudos, por ser de interesse para os sociólogos de países em desenvolvimento econômico (países cuja organização social global acha-se portanto em rápida e drástica transformação), essas análises quase sem exceção não enfocam o que era fundamental para Max Weber, a formação mesma do padrão burocrático, a partir de padrões e estruturas de outra natureza (por exemplo, patrimonialistas) . Conceitos da categoria deste último mal são mencionados naquelas análises. Isso é compreensível tendose em vista, de um lado, a tradição anterior da sociologia industrial nos países altamente industrializados, isto é, a tradição da abordagem das relações humanas, e, do outro, o grau de burocratização das empresas desses países. A herança intelectual européia faz-se sentir com maior nitidez nos estudos do segundo grupo que trataremos a seguir, onde são colocados os problemas das interrelações da indústria e da sociedade.

Mesmo pesquisas realizadas nos países industriais passaram com maior freqüência a serem feitas no contexto da organização social global e das grandes tendências de mudança social. Ainda mais significativo é o despertar do interesse pelos projetos de estudo comparativo. Do primeiro tipo de pesquisa, citemos um único exemplo que nos parece particularmente apropriado para sublinhar a modificação de ponto de vista havida, partindose dos estudos realizados com a abordagem pura das relações humanas. É representado pelo artigo de Goode e Fowler ${ }^{12}$, em que mostram resultados opostos aos de muitos estudos de relações humanas. Estudaram uma pequena fábrica fornecedora de peças para uma grande indústria de montagem de automóveis e os resultados obtidos só são explicáveis por essa inserção da fábrica na estrutura do ramo (e suas decorrências tais como o tipo de mão-de-obra empregada: marginal, de pequena probabilidade de

${ }^{12}$ William J. Goode e Irving Fowler, "Incentive Factors in a low Morale Plant", American Sociological Review, vol. 14, n. 5 (outubro de 1949), p. 618-624. 
emprego alternativo). Nessa pequena empresa, como indica o título do trabalho, encontra-se uma correlação entre baixo moral e alto nível de produtividade. No mesmo sentido dessa pesquisa deve ser mencionado o artigo teórico de Siegel ${ }^{13}$, explicitando o "ambiente econômico das relações humanas no trabalho".

A consciência, porém, por parte dos sociólogos dos países industriais, da necessidade de considerar, ao se estudar o que ocorre dentro da empresa, os fatores econômicos e sociais gerais, proveio dos trabalhos realizados em países subdesenvolvidos em vias de industrialização ${ }^{14}$. As análises levadas avante pelo Projeto Inter-universitário de Estudo da Mão-de-Obra durante o Desenvolvimento Econômico, onde a ênfase é posta no caráter da elite industrializadora (dinástica, de classe média, de intelectuais revolucionários, de administradores coloniais e de líderes revolucionários), constituem o exemplo mais frisante ${ }^{15}$. Nessas análises o caráter da administração, os modos de recrutamento do pessoal, as formas de sindicalismo e de conflito industrial etc., são relacionados a tais tipos de elite, alcançando-se assim uma visão das relações de trabalho inseridas na organização social global.

Preponderam ainda talvez as contribuições no sentido da concepção tradicional das relações humanas. A sua influência - a das idéias de Elton Mayo e de Kurt Lewin - transpõe as fronteiras dos Estados Unidos e pode ser facilmente observada em pesquisas, análises e ensino da sociologia do trabalho na França, na Inglaterra, e em muitos outros países ${ }^{16}$. As duas

${ }^{13}$ Abraham J. Siegel, "The Economic Environment in Human Relations Research", in Research in Industrial Human Relations: A Critical Appraisal (orgs. C. M. Arensberg et al.), Nova Iorque: Harper \& Brothers, 1957, p. 86-99.

${ }^{14}$ Whyte escreve sobre um "despertar súbito" (rude awakening) dos sociólogos americanos, decorrente do seu contato mais íntimo e freqüente com países industriais, não ocidentais, ou com aqueles em vias de desenvolvimento econômico. Ver William F. Whyte, Men at Work, Homewood: The Dorsey Press, 1961, p. 57-67, apud Jean-René Tréanton e Jean-Daniel Reynaud, op. cit., p. 125.

15 Ver as sínteses desses trabalhos em Frederick H. Harbison e Charles A. Myers, Management in the Industrial World: An International Analysis, Nova Iorque: McGraw-Hill Book Co., Inc., 1959, e Clark Kerr, John T. Dunlop, Frederick H. Harbison e Charles A. Myers, Industrialism and Industrial Man: The Problems of Labor and Management in Economic Growth, Cambridge, Mass.: Harvard University Press, 1960.

${ }^{16}$ Escrevem Tréanton e Reynaud: "On peut affirmer sans exagération que la plupart des tendências que se notam na sociologia industrial e que foram, grosso modo, delineadas acima são, porém, as que mais interessam para os países que estão agora envolvidos no processo global de transformação de sua economia e sociedade. A ênfase deve ser na compreensão das relações de trabalho, dentro da matriz da organização da empresa e da estrutura social, vistas uma e outra como fenômenos em transformação. É este o modo de se colocar a problemática da sociologia nesse campo: com a perspectiva da sociedade em mudança, onde empresa, sindicato e pequenos agrupamentos de trabalho se inserem. Os fenômenos no nível da microssociologia do trabalho, se assim podemos nos expressar (motivação para o trabalho, chefia etc.), não podem ser entendidos isoladamente. A natureza dos padrões de organização da empresa precisam ser concebidos como em processo de mudança, como de fato estão. A própria sociedade de classes e nessa a classe operária e a dos empresários industriais - acha-se em processo de constituição.

Os estudos reunidos neste volume foram realizados dentro dessa concepção. Fundamentam-se em duas pesquisas: uma de uma fábrica de tamanho médio da cidade de São Paulo (cujos resultados acham-se relatados principalmente nos capítulos 2 e 3), outra das indústrias de duas cidades do interior de Minas Gerais (cujo sumário encontra-se no capítulo 5). Os capítulos 4 e 6 utilizam-se, num amplo contexto de material comparativo, dos dados de ambas as investigações.

Os temas se entrelaçam. Os capítulos 2 e 6 tratam, respectivamente, da formação da classe operária e das modificações que por força da industrialização se operam na natureza da estratificação social. O caráter da organização da empresa - a permanência de elementos tradicionais e o processo de racionalização, entre outros problemas - é objeto de estudo nos capítulos 3 e 5. Aspectos particulares do trabalho industrial e da empresa, as comunicações internas e a motivação para o trabalho, respectivamente, vistos ambos na perspectiva da organização da empresa e na da sociedade,

travaux de sociologie industrielle publiés depuis 1945 portent l'empreinte de l'école de Harvard (encore désignée sous le nom d'école des relations humaines), dont ce livre (Management and the Worker) aura été l'un des grands moments. L'autre influence majeure qui s'y est ajoutée et qui a profondément marqué la période 1945-1950 est celle de Kurt Lewin et du groupe de chercheurs qu'il avait rassemblé autour de lui à l'Université de Michigan." Op.cit., p. 123. 
são assunto dos capítulos 3 e 4. Esses são os temas mais amplos dentro dos quais caem as análises efetuadas nos vários capítulos. Relatos de pesquisa que são, não se poderia esperar tratamento exaustivo. Pretendem apenas ser contribuição para o esclarecimento desses temas.

Cabe ainda esclarecer que esses artigos são aqui republicados, com poucas exceções ${ }^{17}$, como apareceram pela primeira vez. Apresentam; portanto, certa duplicação de material (embora não de análise) que não nos pareceu inconveniente conservar.

\footnotetext{
${ }^{17}$ A principal exceção é constituída pelo capítulo 5 que teve alguns de seus parágrafos reescritos. A análise nesse caso foi alterada devido à elaboração do material de pesquisa, posterior à sua primeira publicação em 1961 pela revista Sociologie du Travail. Mudou-se
} pela mesma razão um pequeno trecho do último capítulo.

\section{Capítulo I}

O ajustamento do trabalhador à indústria: mobilidade social e motivação

\section{Colocação do problema}

O crescimento da indústria é, em São Paulo, o principal fator responsável pela mudança estrutural nas classes ocupacionais, principalmente nos níveis de trabalho semiqualificado e qualificado. Este estudo dedica-se ao exame de alguns aspectos da mobilidade ocasionada por essas modificações na estrutura de ocupações provocadas pela indústria. Entre as várias formas que assume esta mobilidade, focaliza este trabalho a passagem de lavrador (ou trabalhador de baixo status social e de comunidades semi-rurais) para operador de máquina em fábrica e a ascensão de indivíduos, em muitos casos de origem, em última instância, rural e outras vezes também de origem estrangeira, ao nível de operário qualificado, o que se dá em geral depois de duas ou três gerações de ajustamento à vida urbana.

O centro de interesse é portanto, o trabalhador brasileiro de origem rural próxima ou remota, embora às vezes seja ele de origem estrangeira. $\mathrm{O}$ problema em questão é o dos ajustamentos de comportamento no trabalho exigidos desse trabalhador, cuja mobilidade social tantas vezes se combina à geográfica. Foram examinados, primeiro, aspectos do trabalho e da vida dos operários brasileiros nascidos no campo, no seu meio original e, depois da sua migração para a cidade, os fatores culturais que condicionam a sua permanência ou não na sociedade urbano-industrial. A mobilidade social, além de representar um movimento vertical de uma classe para outra, acarreta com o tempo uma mudança do comportamento da pessoa que sobe ou desce na estrutura social. Por isso, a seguir, foi considerada a conduta do operário semiqualificado no trabalho e os fatores sociais que determinam o seu nível de produtividade, inclusive a influência do controle social exercido pelo grupo, assim como a de valores tradicionais relativos ao trabalho. Foram focalizadas as possibilidades de ascenderem esses trabalhadores na indústria e de realizarem assim um ajustamento permanente, para afinal ser feita uma análise da origem social e do 
comportamento dos operários brasileiros que adquiriram um ofício qualificado e que representam um estágio adiantado desse ajustamento.

O fluxo de mobilidade examinado é o de indivíduos que realizam muitas vezes uma mudança radical de ambiente, transpondo literalmente em poucos dias várias épocas de evolução sócio-econômica. Para o estudo sociológico deste processo de mudança e ajustamento, é necessário analisar antes a motivação e a conduta econômica em sociedades tradicionais e na urbano-industrial.

A pressuposição de que a ação econômica é racional isto é, resulta do cálculo rotineiro de "custos" e "lucros", pelo empresário, e de "vantagens" e "desvantagens" do emprego, pelo trabalhador - é a base da explicação teórica pela Economia do funcionamento do sistema capitalista.

Embora essa concepção do "homem econômico" seja satisfatória do ponto de vista da teoria econômica, ela não o é sob o da Sociologia. Para esta, o comportamento no trabalho, como qualquer outra ação humana, deve ser encarado como parte de uma estrutura institucional. Parsons ${ }^{1}$, na sua análise da motivação das atividades econômicas, escreve que, em qualquer sociedade, as ações individuais são parte de uma estrutura social, que compreende um sistema de papéis sociais, uma estrutura de autoridade e de direitos e uma escala de estratificação social. A ação econômica não é uma exceção; as expectativas de comportamento ligadas aos papéis ocupacionais, a autoridade do contramestre ou do empregador, o direito à estabilidade, as graduações sociais baseadas na renda ou no prestígio das ocupações etc., derivam de um corpo de normas institucionais que estruturam o comportamento do homem no trabalho. O aspecto subjetivo dessa estrutura social é constituído de sentimentos morais tais como: a indignação espontânea quando normas são transgredidas por outrem, o sentimento de obrigação de respeitá-las e a sensação de culpa ao infringi-las. Em sistemas sociais funcionalmente integrados, os "interesses" dos indivíduos são geralmente consistentes com as normas institucionais, não só devido às sanções que a sua quebra provoca, mas também porque, tendo sido inculcadas na infância, fazem parte da personalidade.

${ }^{1}$ Parsons, T., "The Motivation of Economic Activities", in Essays in Sociological Theory Pure and Applied, Glencoe, The Free Press, 1949, p. 200-217.
Fundamentalmente, a motivação do trabalho é a mesma em todas as sociedades: a satisfação de necessidades e desejos, a auto-estima, o reconhecimento social etc. As formas concretas, porém, em que esses motivos básicos se expressam, dependem da sociedade e, por conseguinte, variam. Numa, à guisa de exemplo, o reconhecimento social é obtido pela obediência a normas tradicionais que prescrevem como deve ser realizado o trabalho; noutra, é a engenhosidade na descoberta de técnicas novas e mais eficientes que se valoriza. Particularmente, pode-se concluir que a prevalência do individualismo e racionalismo econômicos em um dado grupo é mais uma questão da sua estrutura social, que da maior ou menor incidência de elementos "egoístas" na psicologia dos indivíduos ${ }^{2}$.

Para alcançar-se o objetivo deste estudo, isto é, a análise do trabalho e da sua motivação no início do processo de industrialização, quando se está apenas a um passo de uma sociedade tradicional, é especialmente útil examinar a forma dada a estes fenômenos pela organização social. Uma tipologia da estrutura institucional dos interesses e atividades econômicos, baseada, em última análise, no contraste entre uma "economia tradicional" e uma "economia de mercado" servirá de arcabouço teórico para este trabalho ${ }^{3}$.

Primeiro, há o trabalho nas sociedades tradicionais. As técnicas e a divisão do trabalho, o ritmo das atividades e a autoridade sob a qual se organizam são prescritos tradicionalmente. Os fatos econômicos derivam de um sistema de relações pessoais. Nos casos mais simples, o grupo que produz é o mesmo que consome. Quando há trocas de bens e serviços entre essas unidades sociais, elas fazem parte de uma teia de obrigações

\footnotetext{
2 "It is thus suggested that the much talked of "acquisitiveness" of a capitalistic economic system is not primarily, or even, to any very large extent a matter of the peculiar incidence of self-interested elements in the motivation of the typical individual, but of a peculiar institutional structure which has grown up in the western world" (Ibid.) p. 214). Os numerosos estudos que evidenciaram os determinantes sociais do "espírito" do capitalismo, entre os quais o mais conhecido e importante é o de Weber, consubstanciam essa conclusão. Mesmo sem entrar no mérito da tese do sociólogo alemão, não há dúvida que as análises do problema por ela provocadas estabeleceram plenamente que o racionalismo econômico longe de poder ser tomado como um ingrediente invariável da natureza humana é um fenômeno cultural, histórico e socialmente condicionado.

${ }^{3}$ Tipologia baseada, com modificações apropriadas aos objetivos deste estudo, nos tipos de ação de Weber, no conceito de sociedade de folk e nos estudos da economia de mercado feitos por Polanyi e Weber.
} 
recíprocas, ao invés de se efetuarem em um "mercado", como na sociedade capitalista moderna ${ }^{4}$. Não é só o papel que cada pessoa, dependendo do seu status no grupo, tem no "processo de produção", que é tradicional, mas também o que ela "recebe" no "processo de distribuição". Os princípios básicos de comportamento que sustentam a ordem de produção e distribuição, segundo Polanyi ${ }^{5}$, são o de reciprocidade, quanto a presentes cerimoniais, prestação de serviços etc. (dependente por sua vez da simetria que em geral existe nas partes componentes da organização social) e o da redistribuição pelo qual os bens são compartilhados por meio de instituições tradicionais, como, por exemplo, a entrega, para redistribuição, da caça ao chefe do bando, pelos caçadores.

Em sociedades tradicionais, o homem tem "a sua economia

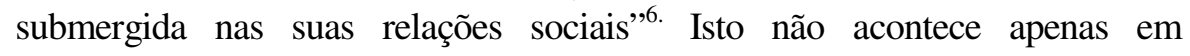
sociedades de folk, mas também em sociedades bem mais heterogêneas e complexas, como é o caso de muitas das civilizações antigas e do mundo feudal. "A terra, o fulcro da ordem feudal, era a base dos sistemas militar, judiciário, administrativo e político; a sua condição legal e função eram determinadas por preceitos legais e costumeiros. $O$ fato de ser ou não transferível a sua posse, e, no caso afirmativo, a quem e sob que restrições; que direitos a sua propriedade conferia; a que uso alguns de seus tipos podiam ser destinados - todos estes pontos estavam fora do sistema de compra e venda e sujeitos a uma regulamentação institucional de ordem inteiramente diversa". O mesmo acontecia com o trabalho sob o regime corporativo ${ }^{7}$.

O trabalho, em sociedades tradicionais como essas, é assegurado, não pela expectativa social de que os indivíduos agirão de modo a obter o máximo de recompensas materiais pelos seus esforços, mas sim por

4 "In the folk society, ideally conceived, nothing is solely a means to an immediate practical end. All activities, even the means of production, are ends in themselves, activities expressive of the ultimate values of the society... The distribution of goods and services tends to be an aspect of the conventional and personal relationship of status which make up the structure of the society: goods are exchanged as expressions of good will and, in large part, as incidents of cerimonial and ritual activities." Redfield, R., "The Folk Society", The American Journal of Sociology, 1947, 52, n. ${ }^{\circ} 4$, p. 304 e 305.

${ }^{5}$ Polanyi, K., The Great Transformation, Boston, Beacon Press, 1957, capítulo 4, p. 43-55.

${ }^{6}$ Ibid., p. 46.

${ }^{7}$ Ibid., p. 69-70. prescrições tradicionais que regulam a forma que esse trabalho deve assumir. A pessoa acha-se moralmente obrigada a tais normas, das quais depende, em boa medida, a satisfação de suas necessidades, a sua autoestima e a obtenção da aprovação dos outros membros do grupo ${ }^{8}$.

Em contraposição, há o trabalho em sociedades baseadas numa economia de mercado? ${ }^{9}$. Com este termo quer-se indicar não a simples existência de mercados - instituição encontradiça nas mais variadas épocas e lugares - mas a situação em que o mercado é o fato central dos sistemas econômico e social. Tal economia pressupõe uma organização institucional, da qual resulta um mercado livre em que bens e serviços, assim como o dinheiro, os meios de produção, a terra e o trabalho, são objeto de compra e venda. Historicamente, essa organização econômica surge com o desenvolvimento da liberdade formal no mercado, pela diminuição das restrições jurídicas e costumeiras à participação no mercado devidas ao status social, e com o seu alargamento, de maneira que muitas coisas, antes fora do comércio, passaram a ser objeto de troca. Na concepção ideal do sistema de livre concorrência, em que se desenvolveram plenamente essas tendências, a regulamentação governamental do mercado é mínima e visa essencialmente garantir a sua liberdade formal. Neste caso, tanto a produção como a distribuição, ao invés de serem diretamente prescritas por valores e padrões da organização social, são controladas pelos preços do mercado; a produção, porque dos preços depende o lucro dos que dirigem

${ }^{8}$ Raymond Firth, examinando os incentivos ao trabalho entre os habitantes de Tikopia, escreve: "The simplicity of (the) symbols of achievement is interesting. The good fisherman, the good gardener, gets no extra pay. One may wonder how the simple act of sticking up ones fishing rod at the back of ones canoe should be so highly prized or the right to make a song about oneself. Yet it is precisely in these non-material ways that the human being in a society finds some of his most cherished goals. And they are goals, of course, only because he lives in a society. It is the opinion of his fellows that gives value to these simple tokens. It is the rivalry of his fellows, expressed or not, which helps to spur him on.

"In, a simple society of this kind the social controls of labour are often directly evident. Labour is a scarce good in the economists sense. One of the ways by which it is secured is not to offer it any high material inducement, but to put it on a footing of social obligation. In particular people go and work for other people because they are relatives". "Anthropological Background to Work", Occupational Psychology, 1948, 22, n. ${ }^{\circ} 2$, p. 96.

${ }^{9}$ Cf. Polanyi, K., op. cit., capítulos 5 e 6, p. 56-76 e Weber, M., The Theory of Social and Economic Organization, Nova Iorque, Oxford University Press, 1947, p. 181-184; também são relevantes os estudos de Weber, de sociologia das religiões. 
as empresas; a distribuição, porque ela é determinada pela renda dos indivíduos (e não pelo seu status), renda que, em última análise, depende de "preços", como sejam os salários, os lucros, os juros e os alugueres da terra.

Essa estrutura econômica tem como complemento essencial para o seu funcionamento, um sistema de idéias e valores sociais. A atividade aquisitiva é aprovada; a expectativa social é que as pessoas procurem a consecução dos seus interesses econômicos individuais. A conduta econômica, segundo os padrões existentes nesse tipo de sociedade, deve ser racional, isto é, deve ser orientada pela ponderação sistemática de "meios", para a escolha dos mais eficientes para a consecução dos fins em vista e, para isso, valorizam-se as inovações. Enquanto nas sociedades tradicionais, os padrões prescrevem qual deve ser o conteúdo do comportamento, aqui apenas é especificada a forma racional da conduta; o seu conteúdo (os "meios" adotados para a realização dos próprios interesses) varia conforme as forças impessoais do mercado.

É claro que nenhuma sociedade pode estar inteiramente baseada no princípio do mercado. A questão é sempre de limites, de natureza ${ }^{10} \mathrm{e}$ amplitude variáveis, dentro dos quais não só é legítimo, mas mesmo se espera, que as ações dos indivíduos, ao invés de serem determinadas pela tradição, sejam guiadas racionalmente pelos seus interesses econômicos.

A classe operária em São Paulo se está formando à custa da imigração estrangeira e, principalmente, de migrantes do Brasil rural este estudo trata, como já ficou dito, destes últimos. A vinda de um sem-número de pessoas das zonas rurais, para ocupar nas indústrias lugares que não exigem qualificação, cria problemas de ajustamento, cuja natureza se torna mais clara quando se considera que esses migrantes, no seu ambiente original, trabalhavam numa economia que se aproximava em maior ou

${ }^{10}$ A atuação do mercado livre pode sofrer restrições que não são de cunho tradicional, mas resultam preponderantemente de ação racional. Tais são as limitações decorrentes da formação de sindicatos de operários, de cooperativas de consumo, de acordos e fusão de empresas ("gentlemens agreements", "trusts", oligopólios e monopólios), assim como da interferência do Governo no campo econômico. Uma economia inteiramente planificada é o caso extremo em que a instituição do mercado desaparece por completo. Entretanto, ao passo que nas sociedades tradicionais não existe um mercado porque a ação econômica decorre das normas costumeiras do sistema social, na sociedade planificada ele não existe porque aquela ação é prescrita por normas racionais de uma organização burocrática. menor grau do tipo encontrado em sociedades tradicionais e que, ao juntarem-se ao operariado fabril da cidade de São Paulo, passaram a participar de uma economia racional de mercado.

É dentro deste quadro de referência que se estuda neste trabalho o ajustamento do homem de origem rural ao trabalho industrial. De início, analisam-se as condições que muitas vezes tornam instável o novo status e os de terminantes do seu comportamento na fábrica, e, em seguida, sob outro ângulo, examina-se a origem do operário qualificado brasileiro, para verificar a extensão do ajustamento efetuado no seu comportamento e quantas gerações o separam do mundo rural.

\section{A fixação do operário de origem rural na indústria}

As mudanças econômicas e sociais resultantes do surto cafeeiro e da industrialização no Sul do Brasil criaram, para usar a expressão de Jacques Lambert, os "dois níveis da civilização brasileira" de hoje. As comunidades rurais, isoladas e tradicionais, dispersas pelo enorme território nacional e "que trazem ainda a marca do século XVI e da escravidão", embora apresentem diferenças regionais de valores, padrões e estrutura social, contrastam claramente, como um todo, com o "Brasil novo". Este resultou da quebra do isolamento provocada pelo impacto da agricultura e indústria modernas em partes do Sul e nos principais centros urbanos de outras regiões, onde as populações foram integradas numa sociedade mais heterogênea e complexa. $\mathrm{O}$ processo continua. Com o desenvolvimento econômico, novas partes do Brasil são incorporadas à sociedade urbano-industrial. Um aspecto desse quadro são as migrações internas, que significam "abandono do Brasil arcaico e incorporação ao novo" ${ }^{11}$.

Elas fornecem parte preponderante da mão-de-obra da nova economia e incluem a migração nordestina, que, impulsionada pelas condições mesológicas daquela região, se dirige para a agricultura e indústria do Sul, bem como o êxodo de gente da zona rural circundante para as cidades, principalmente para as metrópoles.

${ }^{11}$ Lambert, J., Le Brésil, Paris, Librairie Armand Colin, 1953, p. 64-82. 
Para examinar o problema do ajustamento desses rurícolas ao trabalho semiqualificado industrial, foi realizada em São Paulo uma pesquisa numa fábrica de tamanho médio. As conclusões deste trabalho são, portanto, na melhor das hipóteses, apenas parcialmente válidas, se se tratar de indústrias que atraem uma mão-de-obra diversa da estudada. Deve-se observar também que o fenômeno em questão inclui a transformação de pessoas, vindas do meio rural, em operários radicados na comunidade urbano-industrial e assimilados ao seu modo de vida, e o aparecimento de tradições, ideologias e formas de ação coletiva (econômica e política) que os unem e os distinguem dos outros grupos dessa comunidade. Examina-se, nesta parte do trabalho, apenas o aspecto desse processo que trata da fixação do operariado de origem rural na moderna sociedade industrial.

\section{Formação da fábrica estudada}

A Companhia foi formada em São Paulo há alguns anos por brasileiros e europeus, estando estes últimos, no mesmo ramo industrial, no Brasil, desde o período imediatamente anterior à última guerra, com a assistência técnica de uma firma européia. Essa firma enviou especialistas que, juntamente com outros europeus que já se encontravam em São Paulo e foram eventualmente empregados pela Companhia, ocupam hoje as principais posições técnicas e de chefia (gerente de produção, mestres e contramestres) e constituem a maior parte dos operários qualificados. Do ponto de vista étnico, portanto, o pessoal de nível inferior na hierarquia da fábrica é, em grande parte, brasileiro e os que estão nos escalões superiores (a partir mesmo do nível de trabalhador qualificado), na maioria, são imigrantes recentes ${ }^{12}$.

${ }^{12} \mathrm{O}$ número de empregados da firma, nas oficinas e no escritório, flutuou, durante o período de coleta de dados, ao redor de 500 . Houve um aumento gradual do pessoal na primeira metade de 1956, seguido depois de vários "cortes" no segundo semestre do ano e no começo de 1957, devido à contração do mercado provocada pelas medidas de restrição de crédito tomadas pelo Governo Federal. A mão-de-obra é quase toda masculina; as mulheres, 10,5 por cento do total, estão quase todas no escritório e na seção de testes.
Natureza do processo de trabalho e qualificação exigida do trabalhador

Dois produtos são fabricados na Companhia. As oficinas constam das seguintes partes principais: fundição, quatro "linhas" de produção, seção de manutenção, seção de controle de ferramentas e de aparelhos de medida, ferramentaria e seção de testes (controle do produto acabado). Outras seções menores (almoxarifado, almoxarifado de ferramentas, depósito) completam o quadro.

O processo de produção é em série. As peças fundidas passam por uma "linha" de máquinas semi-automáticas (tornos, retíficas etc.), sendo uma ou duas operações executadas em cada uma delas por operários semiqualificados, ficando as peças prontas no fim da "linha". "Controladores de máquina", subordinados ao mestre da linha, ajustam as máquinas seguindo as especificações do desenho da peça a ser fabricada. "Controladores de relógio", da seção de controle de ferramentas e aparelhos, ajustam os aparelhos de medida localizados ao lado de cada máquina, para que os operadores, de quando em quando, possam verificar se as operações que executam nas peças estão dentro dos limites de tolerância. "Controladores de qualidade", pessoal mais qualificado da mesma seção, tomam a esmo peças semi-acabadas e medem as operações executadas, diretamente na peça, a fim de descobrir em tempo erros e tomar as providências necessárias, entrando em contato com os controladores de máquina e de relógio, para que estes reajustem as máquinas ou aparelhos de medida. Finalmente, todas as dimensões da peça acabada são novamente verificadas na seção de testes.

Portanto, quase todo o trabalho nas oficinas, especialmente na fundição, nas linhas e na seção de testes, ou não exige qualificação ou é semiqualificado (neste último caso o operário geralmente o aprende em alguns dias ou, no máximo, semanas). O trabalho técnico e qualificado restringe-se, principalmente, ao dos mestres e contramestres, controladores de qualidade, e operários da ferramentaria e da seção de manutenção, ao todo, cerca de $18 \%$ do pessoal.

\section{Origem dos trabalhadores}

Os operários não qualificados e semiqualificados são pessoas que na sua quase totalidade vieram de fora da cidade de São Paulo; imigrantes 
estrangeiros constituem quase um quinto do total e migrantes brasileiros, quase três quartos (Ver Tabela). Estes vieram, predominantemente, de sítios e fazendas ou de pequenas comunidades do interior. Podemos afirmar que a maioria dos trabalhadores não qualificados e operadores de máquina, talvez dois terços do total, vieram para São Paulo diretamente do mundo rural. Por outro lado, no nível de operário qualificado, trabalho de supervisão e técnico, uma alta porcentagem é constituída de europeus (quase a metade dos quais alemães) ${ }^{13}$, provenientes de famílias de operários qualificados e de pequenos artesãos.
TABELA: Pessoal da Companhia (a),

(fevereiro-abril 1957) (b)

$\begin{array}{lcccc} & \begin{array}{c}\text { Operários não } \\ \text { qualificados e } \\ \text { semiqualificados } \\ \text { Local de }\end{array} & \begin{array}{c}\text { Operários } \\ \text { qualificados, } \\ \text { controladores e } \\ \text { contra-mestres }\end{array} & \begin{array}{c}\text { Mestres e } \\ \text { técnicos } \\ (\mathrm{N}=329)\end{array} & \begin{array}{c}\text { Total } \\ (\mathrm{N}=400)\end{array} \\ & \% & \% & \% & (\mathrm{~d}) \\ & 7,0 & 14,0 & - & \% \\ \begin{array}{l}\text { Cidade de São } \\ \text { Paulo }\end{array} & 48,9 & 22,0 & & 7,5 \\ \begin{array}{l}\text { Interior de São } \\ \text { Paulo e em outros }\end{array} & & & 4,8 & 43,3 \\ \begin{array}{l}\text { Estados, exceto o } \\ \text { Nordeste (c) }\end{array} & 25,2 & 2,0 & - & 21,0 \\ \text { Nordeste (c) } & 18,9 & 62,0 & 95,2 & 28,2 \\ \text { Países estrangeiros } & 100,0 & 100,0 & 100,0 & 100,0 \\ & 82,3 & 12,5 & 5,2 & 100,0\end{array}$

(a) Excetuado o pessoal da administração e de vendas (44 pessoas).

(b) O quadro foi organizado na base de uma lista dos empregados "horistas" referente a fevereiro de 1957 , e de uma lista dos mensalistas, referente ao fim de abril do mesmo ano.

(c) Incluída no Nordeste, a Bahia.

(d) Do total de 402, foram excluídos dois operários, um da Capital de São Paulo e outro de Minas Gerais, sobre os quais não havia dados para determinar o nível de qualificação.

\footnotetext{
${ }^{13}$ De 51 estrangeiros nesses níveis, 22 são alemães.
} 


\section{O meio rural de origem dos operários}

É mister considerar, antes de mais nada, a proveniência dos operários de origem rural e uma breve descrição de alguns traços da sua vida naquele meio (o regime de trabalho rural, a noção de propriedade, a orientação ocupacional e os padrões de mobilidade), que são úteis para a compreensão do problema de sua fixação no ambiente urbano-industrial.

Esses trabalhadores podem ser divididos em dois grupos principais: dois terços, mais ou menos, nasceram no interior do Estado de São Paulo e em Estados vizinhos (Minas Gerais, Santa Catarina e Paraná) e o restante, na Bahia e no Nordeste. Tanto uns como outros, em geral, trabalharam até adultos com suas famílias na lavoura. Alguns, em menor número, moraram até à adolescência em pequenas cidades ou vilas (suas famílias, entretanto, mantinham estreitas relações com o mundo agrícola) e aí tiveram seus primeiros empregos, em geral no comércio, antes de vir para São Paulo.

Os nordestinos (incluindo neste grupo os baianos), em sua maioria, provêm de famílias de sitiantes e, às vezes, de meeiros. O grupo de trabalho nas suas propriedades é a família numerosa, auxiliada, às vezes, no caso dos sitiantes, por uns poucos empregados. A agricultura é de subsistência; apenas "sobras" eventuais são vendidas nas feiras locais. Nas propriedades de alguns, porém, principalmente nas próximas da zona litorânea, fora do Polígono da Seca, uma parte maior da produção agrícola e da criação é destinada ao mercado. Por outro lado, os operários do interior de São Paulo, embora sejam muitas vezes, como os nordestinos, de famílias de sitiantes e de meeiros, devido à economia mais evoluída da região, plantavam em suas terras café ou algodão (bem como outros produtos) para o mercado, tendo as roças de "mantimentos" para consumo da família um papel secundário nas suas atividades agrícolas. São também mais freqüentes que no grupo do Nordeste os paulistas que eram camaradas ou colonos em fazendas.

Os migrantes paulistas c nordestinos distinguem-se, também, no que diz respeito à propriedade da terra que prevalece nas comunidades de origem. Em muitos lugares do Nordeste, a noção de propriedade do solo está em transição de uma propriedade coletiva familial, na qual todos os membros têm direitos, para uma propriedade individual. Por morte do chefe da família a propriedade não é dividida, continua de todos. Mesmo que emigrem componentes da família, continua a viúva, auxiliada por alguns dos filhos, a viver no sítio, que é propriedade "de todos"14. Várias entrevistas refletem essa situação. Um operário, natural do Ceará, exemplifica: "Eu tenho um terreno. Meu irmão trabalha lá, o que ele tirar (da roça que fizer) é dele". De fato, os seus irmãos que são barbeiro e marceneiro na cidade de Mauriti, têm roças no "terreno" do pai, separadas da do mesmo ${ }^{15}$. Outros entrevistados nordestinos, vindos de lugares onde já há maior comercialização da agropecuária, contam casos em que eles, ou algum parente, vendem a sua parte da propriedade a irmãos, "para ficar na família". A terra tornou-se aí objeto de propriedade individual.

No caso dos informantes vindos do interior de São Paulo, o filho, com o casamento, passa geralmente a ter, embora por vezes de uma forma imprecisa, uma economia separada da do resto da família.

G. A. casou-se aos 21 anos, quando seu pai vendeu o sítio que tinham perto de novo Horizonte (São Paulo) e comprou outro em Maringá (Paraná). Junto com um seu cunhado foi "formar" uma plantação de café na terra do pai, com a combinação costumeira nesses casos: os "mantimentos" e o café que colhessem durante os quatro primeiros anos seriam deles. "Depois de formado o cafezal, íamos combinar como seria, mas veio a geada... Até os 21 anos, trabalhei para o meu pai; faz quatro anos que trabalho para mim."

${ }^{14}$ Escreve Harris sobre uma pequena comunidade na Bahia: "Partition of inherited land is rarely carried out by legal or formal methods. Most frequently the land is held in "common" (comum). But this condition merely means that each heir is permitted to work the amount of land to which his share in the inheritance entitles him without having been demarcated. In the event that an heir as not present his share of the land is not held vacant but is worked by the others. If he should return after a period of absence the others must make room for him. In practice, however, the particular segment which an heir works corresponds to the segment which he worked during the lifetime of the deceased... plus a portion of the land which the latter formerly worked". Harris, M., Town and Country in Brazil) Nova Iorque, Columbia, University Press, 1956, p. 86.

${ }^{15}$ É interessante notar que ao mesmo tempo que a terra não é considerada como objeto de propriedade individual, esta noção é bem clara em relação aos produtos da terra (quando cada membro adulto da família tem uma roça) e à criação. Esse mesmo entrevistado diz que cada filho na sua família tem as suas cabeças de gado. Um outro, da Bahia, descreve como o avô, na época "da marcação do gado, sempre punha a (sua) marca". Mas quanto à terra, é diferente. Um terceiro entrevistado, também de Mauriti, no Ceará, conta que, depois do inventário do seu pai, "cada um dos filhos tem a sua parte (no sítio), mas nada foi dividido, está tudo incluído (tudo junto)". Não é necessário acrescentar que essas partes não são demarcadas. Consistem só no direito ao uso da terra. 
As atividades agrícolas dos nordestinos, como também, embora menos frequentemente, as dos migrantes do interior de São Paulo, aliam-se muitas vezes às comerciais. Os chefes das famílias de muitos operários ocupam-se ao mesmo tempo da lavoura e exercem profissões no pequeno centro comunal. O pai de um pernambucano, por exemplo, além de sitiante, era barbeiro "em casa e na feira". O de um baiano era "fazendeiro e ambulante". Um paulista, de Piracicaba, conta que seu pai tinha um sítio, mas que também trabalhava por conta própria, e acrescenta "o sítio era para manter a família e os negocinhos eram para tocar a vida". Outras vezes, entretanto, um ou outro membro da família, ao invés de exercer ambas as atividades simultaneamente, abandona a lavoura para só dedicar-se a "negócios". Abre então uma loja ou armazém de secos e molhados, ou ainda, trabalha como intermediário na distribuição de produtos agrícolas. $\mathrm{O}$ pai de um operário de São Lourenço do Turvo (São Paulo), enquanto seus filhos arrendavam terras naquela localidade para plantar algodão, foi comprador "por conta própria" de aves e ovos para vender em São Paulo. No caso dos nordestinos, o comércio mais comumente exercido é o de ambulante que compra as mais variadas mercadorias, percorrendo a zona rural e as cidades das redondezas, para vendê-las nas feiras da região. A história de A. P., um cearense, ilustra esse tipo de atividade:

A. P. é o mais moço de três irmãos. Começou a trabalhar com 14 anos no sítio de seu pai. Áos 16 anos vendeu as cabeças de gado que tinha (criadas de "uma cabeça só" dada pelo seu padrinho) e começou "a andar na estrada, tangendo burro, negociando". Comprava e vendia feijão, farinha, arroz, milho, amendoim. "Dava feira todo sábado em Cajazeiras, no Estado da Paraíba. Eu saía de casa na quinta-feira para chegar lá no sábado às 8 horas da manhã. Ia à feira de Cajazeiras e à de Lagoinhas, também no Estado da Paraíba." Ficou nesta vida até os 20 anos, quando veio para São Paulo, porque teve prejuízos e "vivia desgostoso, porque não tinha mais os bens que tinha... Eu vivia naquele fracasso, no meio de minha família tudo mais ou menos...".

Tanto entre os do Nordeste como entre os das zonas próximas da cidade de São Paulo, o maior número de operários brasileiros não qualificados e semiqualificados veio da lavoura. Há, entretanto, entrevistados, que cresceram na sede da comunidade, onde começaram a trabalhar, muito embora a família ou parentes tivessem propriedades agrícolas. Balconista em loja ou armazém, trabalho braçal, ajudante ou pedreiro em construções, ajudante de caminhão e toda a sorte de pequenos empreendimentos comerciais (quitanda, empório etc.) constituem uma lista representativa das ocupações que esses operários tiveram antes de emigrar para o Sul.

A inclinação para atividades comerciais, que se nota tanto nos que vêm da lavoura como nos que moravam em pequenas cidades, é parte de um padrão de independência econômica difundido no Brasil ${ }^{16}$. Neste trabalho interessam as formas - que transparecem nos exemplos dados que toma nas classes baixas rurais, principalmente no Nordeste, esse valor cultural de trabalhar por conta própria, ser independente, valer-se da própria iniciativa e não se subordinar diretamente a ninguém.

\section{A migração}

No Nordeste implantou-se o padrão de migração para o Sul. Embora haja notícias de secas periódicas desde o início do século XVIII, parece que só no final do século passado a fuga à inclemência do meio levou os flagelados a sair da região. Primeiro foi a Amazônia e a borracha que atraíram os nordestinos; agora, São Paulo com os seus cafezais e indústria. Hoje a migração tornou-se talvez mais contínua, não se restringindo apenas aos períodos de seca.

Os nordestinos da fábrica migraram para o Sul, em geral jovens (16 a 22 anos) e sem intenção de se radicarem fora de sua terra, mas para "conseguirem a vida" e depois voltarem. Muitas vezes sós, outras com um parente ou conhecido, raramente vieram acompanhados de várias pessoas da família ${ }^{17}$. Quando se lhes pergunta por que vieram para São Paulo, quase

${ }^{16}$ Harris, no seu estudo de uma comunidade baiana, dedica várias páginas a esse padrão. Harris, M., op. cit., p. 64-74. Entre outras observações, nota o seguinte: "Owning a venda does not bring wealth, but is one of the most desirable occupations known to the community".

${ }^{17}$ Este fato os distingue do grosso da migração nordestina para o Estado de São Paulo, da qual a maioria se dirige para o interior. Dos 305.595 migrantes que passaram pela Hospedaria dos Imigrantes da Cidade de São Paulo, de 1935 a 1939, mais de 75 por cento tinham vindo em grupos de pessoas da mesma família. Lynn Smith, T., Brazil: People and Institution, Baton Rouge, Louisiana State University Press, 1954, p. 277-80. Estatísticas 
invariavelmente respondem: "ilusão... para melhorar". O desequilíbrio entre a população e os meios de subsistência é o fator determinante do abandono da terra. Entretanto, o conhecimento de alternativas - a "ilusão" (fama) das cidades do Sul - e o valor a elas atribuído são essenciais para explicar a direção da migração e a presteza com que se lança mão desse recurso, quando o meio ameaça negar o necessário à vida. Não só a seca, mas um "inverno atrapalhado", ou que demora, lança os mais jovens, que são os que têm maior possibilidade de arranjar trabalho, em direção às cidades ou ao $\mathrm{Sul}^{18}$. Embora, pois, os motivos econômicos da migração sejam os mais importantes (a "melhoração da vida"), o espírito de aventura, a vontade de conhecer mundo, conhecer São Paulo de que tanto se fala, também aparecem nas entrevistas com esses operários nordestinos. "Vim à toa", diz um baiano: "Rapaz solteiro, sabe como é, quer conhecer mundo. Eu sempre gostei de andar, de conhecer mais mundo". Informantes, às vezes, chegam mesmo a salientar que vieram "sem precisão". Um baiano, que veio com um amigo e um primo, diz: "Eu era o único daqueles que vieram de lá que não precisava vir para aqui. Meu primo já precisava porque ele trabalhava mesmo, não como eu (que trabalhava numa loja), mas trabalho mais braçal"19.

referentes ao período de 1941 e 1950 mostram o mesmo fato. Apud Sousa Andrade, C. de, "Migrantes Nacionais no Estado de São Paulo", Sociologia, 1952, XIV, n. ${ }^{\circ} 2$ 2, p. 119.

${ }^{18}$ M. J. declara que onde está localizado o sitio de sua família (Simões Dias, Sergipe) não há seca, mas que em 1956 "o inverno demorou". "Lá chega cedo, março mais ou menos, mas no mês de São João não tinha chegado e me arranquei." Veio para o Rio de Janeiro.

A predisposição para a migração revela-se em frases como a do pernambucano de Garanhuns, que sentenciou: "A gente está ruim de vida, está ruim num canto é preciso correr para outro; tatu é que fica na terra".

${ }^{19}$ Segundo entrevistas de Celeste de Sousa Andrade, são principalmente os grupos familiares que "vêm compelidos por circunstâncias adversas existentes na região de onde procedem", enquanto o migrante individual, moço e solteiro, embora venha também por motivo doe natureza econômica (melhorar sua situação, juntar dinheiro etc.), "vem por desejo de vir mais do que compelido por uma necessidade premente". Op. cit., p. 123-127. Os operários nordestinos da Companhia, como já foi apontado, ao contrário do que é a norma para o movimento migratório global do Nordeste para São Paulo, raramente emigraram para cá em grupos familiares. A maior frequiência, do que era de esperar, de uma motivação não estritamente econômica nesse grupo, é consistente, portanto, com os dados do estudo de Celeste de SOUSA Andrade.
A vinda para São Paulo precisa ser vista, também, como parte da mobilidade dos membros das famílias destes operários. Os entrevistados, muitas vezes, já tinham, antes de virem para cá, saído de sua comunidade e ido para outras cidades ou mesmo para outros Estados e frequentemente não são eles os únicos da família a saírem de casa. As suas famílias, às vezes, têm vários de seus membros fora da propriedade rural.

Entretanto, embora alguns dos seus membros emigrem temporariamente, a família nordestina é presa à terra. No caso dos migrantes paulistas, é o próprio grupo familial que é às vezes desarraigado. A mobilidade na região é processo, pode-se assim dizer, inerente à própria natureza da sociedade que aí se formou. O desbravamento da maior parte do Estado, assim como do Norte do Paraná, que se fez em função de uma lavoura e pecuária para o mercado e utilizando-se de técnicas agrícolas não intensivas, é coisa dos últimos setenta anos. O processo que ainda continua, deu-se por meio de uma contínua migração das zonas velhas para as novas, engrossada primeiro pela imigração estrangeira, e, depois da segunda década deste século, pela migração interna. $O$ rápido esgotamento das terras e a competição com áreas mais produtivas a oeste ou com o Norte do Paraná faz com que zonas, ontem pioneiras, já tenham estacionado ou estejam mesmo a perder população. Há um contínuo movimento de zona para zona e há também um refluxo migratório em direção a São Paulo.

Uma parte considerável dos migrantes do interior do Estado na Companhia veio justamente de zonas cuja colonização começou há pouco mais de meio século (além de São Manuel e Ribeirão Preto), mas que na década de 1940-50 já apresentavam um déficit demográfico. As entrevistas com esses operários revelam, como era de esperar pelo acima exposto, uma mobilidade de toda a família, de uma zona rural para outra. Veja-se o caso de P. A.

Seu pai tinha um sítio de café em São Lourenço do Turvo, no município de Matão. Com a crise do café, vendeu a propriedade e vieram para São Caetano do Sul em 1935, mas ficaram apenas três meses e voltaram para São Lourenço. Seguiu-se um período em que trabalharam, por vezes a família toda, outras apenas os filhos, como arrendatários ou colonos, na cultura de café e de algodão, sucessivamente em São Lourenço, Vera Cruz, Iacri e Tupã. Depois de casar-se, P. A. veio para São Paulo em 1949. 
O migrante do interior de São Paulo, mais frequentemente do que os nordestinos, veio com toda a família com a intenção de aqui permanecer "se der certo". São bem mais raros os que migram sozinhos e solteiros. O motivo da mudança para cá é quase sempre a idéia de "tentar a vida na Capital" ou ver se conseguem melhores condições de trabalho. A migração para esses operários não foi uma mudança tão radical como para os nordestinos. Além do desnível cultural e econômico do meio de origem para o urbano não ser tão grande, tinham frequentemente parentes já radica dos aqui. A volta para sua terra, "se não der certo", ou "não se acostumarem", é relativamente fácil.

Alta proporção dos operários da fábrica é recém-vinda da lavoura e de pequenas cidades do interior brasileiro. Os dados já apresentados sugerem várias idéias pertinentes à fixação de uma mão-de-obra como essa nas indústrias paulistas. Há bastante diferença entre o paulista, mais acostumado com uma agricultura de mercado e com a mobilidade, e o homem nordestino vinculado à economia de quase subsistência do sertão ${ }^{20}$. Entretanto, comparado com o da cidade de São Paulo, o horizonte de um e de outro, embora em grau variável, e fechado e tradicional, sendo de esperar que desse fato resultem obstáculos ao ajustamento dos migrantes ao ambiente impessoal e dinâmico da metrópole. Boa parte dos nordestinos, além disso, não vem com intenção de ficar em São Paulo, mas sim de fazer economias e retornar à sua terra. $\mathrm{O}$ fato de nem toda a família abandonar a propriedade no Nordeste, ou mesmo, quando o faz, de não vender seu pedaço de terra, facilita a volta no caso de necessidade, mesmo que aqui resida há vários anos e seja de esperar que se radique. Por outro lado, outro fator possível de instabilidade na indústria resulta do valor dado por esses campônios, paulistas ou nordestinos, às atividades comerciais em pequena escala, mormente considerando-se as oportunidades para pequenos negócios existentes na grande cidade.

${ }^{20}$ Esta distinção, é claro, é válida apenas grosso modo. O mundo daqueles migrantes das áreas agrícolas mais isoladas do interior do Estado de São Paulo é mais tradicional e estagnado do que o do nordestino das cidades maiores da região ou das zonas rurais próximas das Capitais

\section{Fixação no meio urbano-industrial}

Quão estável é a mudança de status desses camponeses e desses habitantes de comunidades quase rurais que vêm para as fábricas paulistanas? Só com a sua permanência em emprego industrial pode-se esperar com o tempo a transformação de seu comportamento que consolidará o novo status. É preciso, portanto, responder à pergunta: Fixase a mão-de-obra de origem rural no meio urbano e industrial?

Observando-se os empregos dos entrevistados desde que chegaram pela primeira vez a São Paulo, verificam-se muitas vezes freqüentes mudanças de ocupação, não só de um ramo industrial para outro, o que era de qualquer modo de esperar, devido à falta de qualificação dos operários empregados numa produção em série, mas também de fábricas para lojas ou para ocupações marginais como vendedores ambulantes, sob comissão ou por conta própria, ou ainda saindo da cidade para voltar novamente pata a lavoura. Isto é exemplificado pelas listas abaixo dos empregos ocupados em São Paulo por alguns dos informantes, nas quais são indicadas as vezes que voltaram à terra natal e, entre parênteses, o tempo aproximado de permanência em cada ocupação e na zona rural, segundo informações do próprio entrevistado:

\section{S. A. D. (Ibicaraí, Bahia):}

Operário (1 ano e meio) - Volta ao sítio na Bahia (21 dias) Vendedor na base de comissão, em porta de loja (1 ano) - Operário (4 anos).

\section{C. F. (Jaú, São Paulo):}

Lavador em empresa de ônibus ( 3 meses $)$ - Operário ( 8 anos $)$ - Sítio (2 anos) - Operário (2 meses) - Operário (2 anos).

\section{J. J. (Ibiquiara, Bahia):}

Servente de pedreiro ( 2 meses $)$ - Aprendiz de padeiro ( 2 semanas $)-$ Operário (1 ano e meio) - Vendedor pracista na base de comissão (?) Operário (15 dias) - Operário (2 anos e meio).

\section{E. A. (Correntes, Pernambuco):}

Meeiro em Pompéia, São Paulo (1 ano) - Volta ao sitio em Pernambuco (4 meses) - Operário (1 mês) - Arrendatário em Osvaldo Cruz, São Paulo (1 ano e meio) - Operário (1 ano) - Operário (6 meses). 


\section{S. N. G. (Tambaú, São Paulo):}

Operário (3 anos) - Operário (10 meses) - Empregado no comércio (1 ano e meio) - Operário (1 ano e 3 meses) - Operário (4 anos).

O primeiro aspecto do problema é a fixação no meio urbano. Entre os nordestinos que, como já foi apontado, não vêm com idéia de ficar, a mobilidade da cidade para o campo e vice-versa é comum. Não são raros os que várias vezes vieram para São: Paulo. Depois de ficarem um certo tempo, que pode durar até vários anos, voltam para sua terra natal ou por ocasião de férias, ou quando são despedidos de um emprego, ou ainda quando "pedem a conta", com esse objetivo. Mais tarde retomam, podendo o ciclo repetir. se diversas vezes até se prenderem à cidade ou à zona rural de origem.

Em alguns casos, o migrante, seja do interior do Estado ou do Nordeste, estranhou de tal forma São Paulo na primeira vinda, que aqui ficou apenas alguns dias, permanecendo mais tempo só numa segunda viagem.

L. P. A., de Inajá, Pernambuco, onde sua família tem um sítio (terra "quase tudo seca"), veio sozinho, quando tinha 26 anos de idade, para "ver se melhorava a vida", mas ficou apenas seis dias porque" (achou) a vida agitada, não (gostou)". Voltou novamente três anos mais tarde e foi para o interior do Estado, mas "não deu certo" e depois de um mês estava na Capital. Ficou dessa vez mais de um ano, mas, quando foi dispensado em agosto de 1956, voltou para o norte.

C. C. F., que era camarada em uma fazenda perto de Jaú (São Paulo) veio para a Capital em 1924, quando tinha 20 anos. Ele conta: "Não acostumei... Vivia no sertão, criando gado, cheguei aqui e senti muita falta daquela vida". Ficou apenas uma semana. Voltou novamente para São Paulo em 1943, onde está desde então, com exceção de dois anos durante os quais foi para um sítio.

Vencidas as dificuldades iniciais, a atração da vida da cidade, principalmente para os jovens e solteiros ("quando se chega em São Paulo, disse um sitiante baiano, não dá mais vontade de ir embora"), e a comparação do trabalho urbano com o agrícola são fatores importantes para a fixação na cidade. Entre os que trabalharam na terra, esta tarefa é considerada, quase sem exceção, como muito mais árdua do que qualquer serviço na cidade, mesmo que sejam longas as horas de trabalho. Trabalhar debaixo de sol e chuva ou no orvalho da manhã são continuamente lembrados como simbolizando a luta na lavoura. Um paulista, para explicar a decisão de mudar-se para a Capital, alude ao dó que sentia ao ver "aquelas (suas) filhas todas, trabalhando, cortando cana" no orvalho da manhã. Outro afirma que "na lavoura não tem horário para começar, mas (também) não tem para acabar". Assevera um cearense que "na roça é muito duro" e acrescenta logo: "Não é questão de disposição para o trabalho, que isso eu tenho, mas de ter muito trabalho perdido" (a incerteza da recompensa da faina do campo é frequentemente lembrada, especialmente pelos nordestinos). Ninguém hesita em dizer que na fábrica, onde trabalham dez horas por dia, "é muito mais folgado".

Os problemas enfrentados pelo migrante na cidade e, com a gradual acomodação a essa vida, o seu desligamento da rural, são ilustrados pela história de S. N. A. de Santa Rita do Passa-Quatro (São Paulo):

Nos primeiros meses, diz S.N.A., eu não me conformava em ficar separado de minha família. Antes (no interior) a gente se via de manhã à noite. Sou muito enérgico com as minhas filhas. Eu (no emprego) ficava pensando nelas: que estão fazendo, que está acontecendo? Eu, no meio de gente estranha, achava tudo muito sem jeito. Quis voltar." Depois de estar um ano aqui, ficou aborrecido com desavenças que teve com seu senhorio, que queria aumentar o aluguel, resolveu voltar para a fazenda onde haviam trabalhado oito anos e foi até lá. Conversando com seu ex.chefe, pensava: "Será que vou pegar na enxada, carpir cana?" Voltou para São Paulo. Aqui está há onze anos, tendo ido à sua terra algumas vezes para passear. "A última vez que fui, foi há três anos. Vai... estranha. Casa, tudo sujo. A gente já desambientou daquilo. Lamparina, tudo escuro. A gente estranha muito.

Às vezes, mesmo quando continuam com a intenção de economizar e eventualmente voltar para sua terra e reiniciar em melhores condições a lavoura, ou mais frequentemente, começar um "negócio", não conseguem poupar o suficiente e vão ficando.

Um cearense, A. P., que veio em 1949 com 20 anos de idade, depois de ficar três anos e meio numa firma em Santos, "arrumou" para o chefe mandá-lo embora e recebeu mais de treze mil e quinhentos cruzeiros. "Eu estava para ir embora e não voltar mais aqui, conta, mas cheguei lá (no sítio de seus pais, em Mauriti) e achei tudo mudado. Meus parentes tudo bem de vida e eu só com dinheiro micho, não dava para começar nada." E explica o 
que achou diferente: "As coisas, tudo caro. Os modos do terreno estavam mudados. Quando saí tinha muita benfeitoria; depois meu pai ficou sozinho, as frutas, estava tudo quase só mato. Outra coisa: o clima de lá. Eu já estava acostumado aqui; achei muito quente lá".

Entretanto, principalmente para os nordestinos, que têm alguém da família permanecendo no sítio, mesmo aqueles que não têm "mais vontade de ir embora", a propriedade rural da família oferece sempre uma alternativa que é preferida ao desemprego ${ }^{21}$. Pessoas que há anos estão em São Paulo, olham para o sítio da família como coisa sua, com que podem contar. Assim, o sistema de propriedade coletiva, antes referido, em que as terras são "comuns" a todos da família, serve como um elo que une o operário ao mundo rural. Um baiano que está aqui há quase oito anos, tendo neste tempo casado com uma paulista e voltado à sua terra apenas para uma curta visita, refere-se ao sítio de seus pais com as seguintes palavras: "Está guardado, tem quem olhe..." (se eu voltar, está lá).

O casamento e aquisição de propriedade são para os nordestinos outros fatores além dos já mencionados, que levam à sua fixação na cidade; e para os do interior do Estado, "acostumar-se" e conseguir emprego. Mesmo que o migrante rural se radique em São Paulo, entretanto, isto não significa, necessariamente, permanência em trabalho industrial ${ }^{22}$. A orientação psicológica dos entrevistados de origem rural é claramente para fora do sistema industrial.

Muitos declaram que "a ser empregado é melhor na fábrica do que na roça", mas com isto se referem ao esforço exigido pela lida no campo, às condições debaixo das quais é executada (sol e chuva) e à incerteza do resultado. Quando afirmam que trabalhar "no que é da gente" (no campo) é preferível a trabalhar "de empregado", é a independência do trabalho

${ }^{21}$ Por ocasião da contração de negócios do meio de 1956 para cá, em vários casos em que foi possível verificar o que havia acontecido com pessoas de origem rural que foram despedidas, elas haviam voltado para a zona rural.

${ }^{22}$ Com esta expressão, não se quer dizer, está claro, permanência em um único emprego, mas a continuação na situação de operário; ser operário deixando de ser um estado do momento para ser uma condição social relativamente permanente. Segundo cálculo de Simiand, no grupo operário na França em 1921, 66 por cento permaneceriam nessa situação durante toda a sua vida. Apud Halbwachs, Mo, Las clases sociales, tradução do francês, México: Fondo de Cultura Economica, 1954, p. 107. agrícola que valorizam. Um operário, que trabalha "de empreitada" numa fazenda do interior de São Paulo, diz que lhe custou acostumar-se com "não poder sair" (da fábrica) e explica: "No interior estava trabalhando e a gente resolvia: bem, vou embora, preciso ir para o comércio (cidade)". Seu pai conta:

Uma vez na fábrica R. (primeiro emprego que teve em São Caetano, depois de aqui chegar há dez anos) fiquei olhando, aquelas paredes.. e disse para o chefe: faz minha saída, vou embora. ele disse que não. Não quer dar, eu saio, falei, não estamos na escravidão! Ele fez a saída, falando: este povo do interior é uma coisa. Saí, respirei aquele ar puro. Depois, é que fui pensar: fui perder aquelas cinco horas de serviço; foi só aquela vez". Acrescenta: "Lá (no interior) a gente tem liberdade, aqui não tem.

Um baiano, J. J. de Ibiquiara, que saiu de sua terra há quase 14 anos e casou-se com uma mineira declara: "Olha, eu tenho muita vontade de ir para o sítio de meu sogro. Tenho muita vontade de trabalhar na lavoura; quem trabalha na lavoura pode fazer comércio junto. Mas não como empregado. Eu tenho de ver o negócio ir para a frente. Se tivesse dinheiro, os meus planos eram outros, tocar uma grande lavoura, comércio... Eu estou aqui porque sou obrigado. É onde a gente tem mais oportunidade de ganhar, não é?"

Outros, principalmente devido à insegurança da atividade agrícola, mesmo que a família tenha propriedade rural, preferem ocupações na cidade, afirmando, como um pernambucano, que aqui "a gente já sabe o que está ganhando e na roça não sabe. O dinheiro total é uma certeza e na roça é uma aventura". Aqueles que vieram de pequenas cidades e nunca trabalharam no campo têm também, em geral, em muito pouca conta essa atividade. Todos, entretanto, sem exceção, revelam a atração que sobre eles exerce o trabalho "por conta própria" ${ }^{23}$; atração que se faz sentir mais forte sobre os nordestinos, mas em grau menor, sobre todos. Um pernambucano, por exemplo, confessa em tom desesperançado: ${ }^{23}$ Nota-se, no caso acima citado, a razão que o entrevistado deu para explicar a sua vontade
de trabalhar na lavoura: "Quem trabalha na lavoura, pode fazer comércio junto", o que
reflete também a estreita associação já apontada, entre as atividades agrícolas e comerciais (ver p. 29). 
Vou falar para o senhor, se eu pudesse, eu gostaria de trabalhar por minha conta; qualquer coisa que eu mandasse, pode ser qualquer coisa, um empório, um bar, qualquer coisa aí meu, ninguém manda lá, não é?

A liberdade de quem negocia ou se estabelece "por sua conta" é o tema dominante. Um operário do interior de São Paulo salienta que quem trabalha por conta própria "não depende de horário, não depende de chefe". Outro, cearense, de Jucás, afirma que a razão de "estar enfrentando as horas (de trabalho) de noite" 24 é para poder entrar no comércio; e assevera: "Homem que pica cartão não tem futuro; pessoa que trabalha por conta própria é que pode melhorar".

$\mathrm{O}$ trabalho, que querem ter por conta própria, varia. Este, que jamais negociou e acha que "de vinte mil cruzeiros em diante, qualquer coisa, para lá (onde mora), dá", provavelmente planeja ser "ambulante", profissão com a qual está familiarizado em sua terra. Para aquele, é "uma quitandazinha, uma viração". Outro, que tomou conta da loja de seu avô, numa pequena cidade da Bahia, pensa em "conseguir comprar um carro e trabalhar por sua conta". Disse também: "se conseguisse capital (voltaria para o norte), para me estabelecer, não na minha terra, mas noutra cidade, mais civilizada; a minha terra, sabe como é, é um pouco atrasada". Ainda outro, do Ceará, tem "vontade de montar uma oficina de móveis". Já comprou um motor e calcula que, para principiar, precisaria pelo menos de uns cem contos.

Às vezes o operário, sem largar o emprego, aproveita o tempo livre para fazer negócios ou trabalhar como vendedor ambulante. Um baiano, por exemplo, vende terrenos; dois irmãos operários, no sábado e domingo, trabalham com os outros irmãos que são vendedores ambulantes de roupas.

Como era de esperar, os entrevistados, muitas vezes, procuram entrar, com ou sem sucesso, em ocupações por "conta própria" (ver exemplos na pg. 34-35).

Os colegas de A. S., natural de São Paulo, contam que ele estava fazendo dívidas, o seu salário não dava e pensou que, sendo mandado embora, com o dinheiro que recebesse de indenização, poderia começar a

${ }^{24}$ Até o inicio de 1957 os operários da fábrica trabalhavam uma semana de dia e uma de noite. negociar com alguma coisa. Ele, embora não diminuísse a produção, quando a máquina tinha qualquer defeito, parava e sentava ${ }^{25}$. Foi mandado embora no "corte" havido no começo de 1957, mas "parece, diz o informante, que já gastou quase tudo e não dá mais para negociar". (Recebeu 45 mil cruzeiros).

Um operário paulista, filho de italianos, depois de despedido, com 22 mil cruzeiros que recebeu de indenização, foi vender roupas na feira, com seu sogro; outro, mineiro, que era encarregado do grupo de eletricistas na fábrica, saiu para abrir uma oficina de eletricidade; um terceiro, de Piracicaba, conta que saiu espontaneamente de outra fábrica onde era torneiro, com a idéia de comprar um bar, mas que não deu certo, porque a pessoa, com quem ia formar uma sociedade, não quis entrar com capital.

Além da possibilidade de economizar do salário o capital necessário para sair da condição de operário, o que provavelmente dará apenas o suficiente para mascatear em pequena escala, vender doces na rua etc. ${ }^{26}$, existe a oportunidade, que é a mais importante, de obter esse capital com a indenização salarial em caso de dispensa de emprego. Por isso, evitam pedir demissão, mesmo que queiram voltar para sua terra, "para não perder os anos que têm de casa". Chegam mesmo, às vezes, a pedir que sejam despedidos, a fim de receber a indenização (ver o caso de A. S.; nota de rodapé $\left.\mathrm{n}^{\circ} 25\right)^{27}$.

Este relato da orientação ocupacional ${ }^{28}$ de operários vindos, na maior parte, do meio rural, mostra a sua predisposição para abandonar a estrutura

${ }^{25}$ Segundo outra versão, A. S. "quando soube do corte da turma da noite na linha de produção, pediu para ser posto fora. Fizeram os cálculos e disseram que era muito. Deixaram "ele" à espera, mas depois mandaram "ele" embora".

${ }^{26}$ Um operário do interior do Estado conta que certa vez ficou "mascateando uns três meses, mas (que) não deu resultado". "A gente precisa de um pouco de capital, esclareceu, e é muito fiado, e, se o sujeito não tem um capitalzinho mais ou menos, leva ele no buraco" (sic).

${ }^{27}$ A administração da fábrica dispensa o operário e paga toda a indenização devida ou "faz acordo", pagando apenas parte da indenização, ou porque conclui que o empregado não é ou não será dai em diante eficiente, ou porque o seu chefe, por amizade ou outro motivo, recomenda a sua dispensa.

${ }^{28}$ Para a finalidade deste trabalho, não interessa analisar a estrutura social em que essa orientação cultural para certas atividades econômicas aparece e os fatores que a mantêm, mas apenas descrevê-la e apontar as suas consequiências na formação de um operariado 
industrial, voltando para a zona rural de origem, a fim de adquirir uma propriedade ou dedicar se a atividades comerciais, ou permanecendo no meio urbano, para aqui dedicar-se a "negócios". Nem todos conseguem, é claro, esse objetivo. Nem por isso perde esta orientação cultural a importância, pois a sua influência faz-se sentir nas muitas tentativas dos operários, embora malogradas, de abandono da condição de operário industrial ou mesmo no seu comportamento diário dentro da fábrica ${ }^{29}$. Qualquer descontentamento, sejam quais forem os motivos (não ser aumentado, ter atrito com o chefe etc.), traz à tona a vontade de sair e tornar-se independente.

M. M. S., um informante da Bahia, diz que em 1955, estava resolvido a sair da fábrica e "fazer um acordo", para obter parte da indenização. Fez um curso de motorista profissional e pretendia tirar a carta, dar entrada para um carro e trabalhar na praça. "Era preferível, esclarece, trabalhar bastante, mas por conta própria, do que ter de trabalhar de noite e ficar marcando o passo" (não melhorar nem em posição nem em salário). Quando tirou a carta definitiva, já era o fim do ano e recebeu um abono de 10 mil cruzeiros. Resolveu: "Já que me deram dez contos, eu fico".

Este mesmo operário relata: "Antigamente quando eu tinha de trabalhar de noite, (isso) era motivo grande" para querer ser mandado embora e receber indenização. "A gente (neste caso) conversa com os outros ou com o próprio chefe: Eu gostaria de ser mandado embora e receber toda indenização por lei; prefiro a trabalhar de noite. Falei muitas vezes. Agora, que o trabalho é só de dia, eu não falo mais".

Mesmo neste operário, que já está há sete anos na fábrica e que ficou noivo em São Paulo, estando, portanto, relativamente ajustado à estrutura urbana e industrial, em períodos de insatisfação (trabalho noturno, "marcar passo"), reaparece a vontade de dedicar se a atividades "por conta própria", com a conseqüente mudança de comportamento na fábrica.

Nota-se uma assimilação de certos valores próprios do meio industrial e uma fixação incipiente neste meio, no prestígio atribuído, a "ter

estável.

${ }^{29}$ Ver a parte 3 deste Capítulo, especialmente as páginas 65-71. uma profissão" ou ofício, por operários semi qualificados, adestrados no manejo de máquinas semi-automáticas.

M. L. E., um faxineiro vindo do Ceará, confessa em tom amargo: "Eu queria ser classificado: meio oficial, torneiro e centrador (funções, na realidade, semiqualificadas) são as coisas que eu quero. Precisa pedir ao chefe, mas se a gente pede, tem de deixar a carteira lá e eles põem "ajudante". Isto eu não quero, queria que pusesse uma profissão; "ajudante" não é profissão".

Ser "classificado" numa "profissão" não significa, necessariamente, aumento de salário; mas, no caso de mudança de emprego, a possibilidade de arranjar mais facilmente um outro ou mesmo entrar ganhando mais do que o salário mínimo ${ }^{30}$.

A preocupação de manter, pelo menos na aparência, a mesma "profissão", transparece também no caso de P. P. S., vindo do interior de São Paulo, que embora desde os 15 até os 34 anos, a maior parte do tempo, tenha trabalhado em mecânica (plainador e torneiro), exerceu também outras atividades (mascate, condutor de bonde, apontador em "construção"). Tendo saído da fábrica, onde estava como torneiro, trabalhou durante cinco meses, como ajudante de carpinteiro, empreitando serviço: "Trabalhava quinze dias com um, um mês com outro, só para não fichar na caderneta", e explica: "Se ficha torneiro, depois ajudante, depois servente, fica mal, não?"

A identificação com o emprego industrial parece surgir com a aquisição de qualificação em ofício industrial ou com a obtenção dos primeiros postos de supervisão na hierarquia da fábrica. $\mathrm{O}$ primeiro caso, entre os que têm origem rural, é extremamente raro. Quase todos os operários qualificados brasileiros estão afastados do trabalho agrícola há mais de duas gerações (os estrangeiros, provavelmente, mais). De qualquer forma, a aquisição de qualificação ou a passagem para controlador ou contramestre, se por um lado tende a fixar a pessoa no meio industrial, por outro, a separa dos operários semiqualificados e não qualificados, com os

${ }^{30} \mathrm{O}$ fato de pela Consolidação das Leis do Trabalho, não se poder transferir o empregado para uma função diferente da sua, torna importante para os operários a anotação na sua carteira profissional (Ver 67). 
quais deixa de se identificar. Todos esses problemas são tratados na parte final deste trabalho (pg. 74-84).

\section{Conclusão}

As indústrias tecnicamente mais modernas de São Paulo, em que as funções do processo de produção foram subdivididas de tal forma que podem ser executadas por pessoas sem qualquer experiência industrial, atraem em alta proporção um operariado de origem rural. Além do elemento humano fornecido pelo êxodo rural-urbano na região, recebe a cidade a migração nordestina. Desses migrantes, os que se empregam na indústria resultam, provavelmente, de um peneiramento que exclui aqueles que vêm das camadas inferiores da população rural e das áreas mais isoladas.

Embora, por isso, muitos dos que estão na indústria, mesmo entre os nordestinos, não tenham emigrado devido a uma necessidade premente, quase sempre, tanto os do interior de São Paulo, como os do Nordeste, dirigiram-se para a metrópole paulistana à procura de melhores oportunidades de trabalho. Muitos deles, principalmente entre os nordestinos, pretendem, com as economias feitas na cidade, voltar para a agricultura ou entrar no comércio em sua terra natal. De qualquer modo, venham com a intenção de ficar na metrópole ou com a idéia de, com o que aí ganharem, melhorar a sua situação em sua terra, o desejo dominante de todos é de ser "independentes". Esse valor expressa-se de muitas formas. A lavoura em sua propriedade quando as condições são recompensadoras, a empreitada na agricultura, o ofício de pintor ou de eletricista independente, o de dono de caminhão, e as múltiplas pequenas atividades comerciais, são todos trabalhos "por conta própria" em que o indivíduo não recebe ordens, nem presta contas, segundo seu modo de ver, a ninguém.

Essa independência, portanto, não pode ser encontrada dentro da estrutura industrial. $\mathrm{O}$ emprego fabril, a legislação trabalhista e o sindicato são usados por eles com a finalidade de virem a ter o suficiente para trabalhar "por sua conta". Com as economias que fazem e com a quantia recebida de indenização no caso de dispensa de emprego, tentam a sorte na cidade de São Paulo, como vendedores ambulantes, pracistas sob comissão ou em ocupações marginais (venda de mercadorias na rua, toda sorte de "bicos" e "virações"). Quanto mais altas as aspirações do operário (as dos que almejam, por exemplo, ter quitandas, bares, empórios), tanto menores as possibilidades no meio urbano. São mais acessíveis as oportunidades nas comunidades de origem; donde resulta um refluxo migratório, principalmente quando se tornam mais difíceis as condições de emprego em São Paulo. Ao invés do desemprego, portanto, a depressão do mercado tende a aumentar a corrente de retorno às zonas rurais ou, pelo menos, a diminuir ou estancar a migração para São Paulo.

Mesmo quando permanecem por longo período de tempo em fábricas, os migrantes rurais, estando, por assim dizer, subjetivamente orientados para fora da indústria, não se identificam com a condição de operário. Essa valorização de determinadas atividades econômicas enfraquece a ação coletiva desses operários ${ }^{31}$ e tem, portanto, uma função semelhante à da fronteira econômica na história da classe operária americana. Vários analistas mostraram que, nos Estados Unidos, as possibilidades de migração para oeste e de mobilidade vertical (real numa economia em expansão) retardaram o aparecimento da consciência de classe, pois a expectativa dos trabalhadores de eles ou de seus filhos subirem de classe e deixarem de ser operários, fazia com que não se identificassem com a condição e, por conseguinte, com a ação operária.

Para a indústria, a conseqüência dos valores culturais dos migrantes rurais é a instabilidade da mão-de-obra e o alto índice de turnover. Nota-se certa fixação no meio industrial, embora precária, com a passagem para a categoria de operário qualificado ou para posições de supervisão. O aparecimento de uma mão-de-obra fabril estável parece depender, entre outros fatores, das possibilidades de mobilidade do operário de origem rural dentro da estrutura industrial. Entretanto, antes de uma segunda geração, esta estabilização será provavelmente limitada por certos fatores. Primeiro, o fato de não terem esses operários senão rudimentos escolares, enquanto para chegarem a operário qualificado ou a supervisor, precisariam pelo menos de educação primária (a fim de poderem ler desenhos etc.). Segundo, ser baixa a proporção do pessoal acima do nível semiqualificado nas indústrias mais modernas, mormente nas de produção em série, o que limita enormemente o número dos que têm possibilidades de ascensão.

${ }^{31}$ Quanto à solidariedade grupal desses operários e à sua participação em ação sindical, ver a parte 3 deste estudo, (p. 48-61). 


\section{A solidariedade grupal e a produtividade do operário semiqualificado}

Verificou-se atrás quanto é instável a mudança de lavrador ou de trabalhador das pequenas vilas deste Brasil a fora para o status de operário semiqualificado em fábrica. Considerar-se-á agora em que medida se efetuam modificações na sua conduta econômica com a passagem, embora precária, para o novo status. Convém lembrar que, segundo o sistema de referência esboçado no início deste estudo, esses indivíduos passaram de uma economia que, em maior ou menor grau, se aproximava das do tipo tradicional para uma economia racional de mercado. Procura-se, pois, nesta parte examinar o problema do ajustamento do operário de origem rural à indústria, no que diz respeito ao seu comportamento na fábrica, analisandose as condições em que a conduta racional, orientada por interesses individuais, é socialmente sancionada; a maneira por que tais interesses são definidos pelo grupo, a medida em que o comportamento no trabalho obedece a obrigações e valores tradicionais, e, finalmente, as restrições impostas àqueles interesses por novos valores,relações e formas de solidariedade que surgem no meio industrial.

\section{Forma de pagamento nas linhas de produção}

Preliminarmente, é preciso discorrer sobre o sistema de pagamento na fábrica estudada. Atualmente todos os operários são pagos por hora. Entretanto, existia até fevereiro de 1957, em três das quatro linhas de produção, acrescido ao salário devido ao número de horas trabalhadas, um prêmio conforme a produção. Esse prêmio era individual e de três cruzeiros por cem peças para quase todas as máquinas ${ }^{32}$. Como a produção não apresenta variações muito grandes de máquina para máquina, pois as peças passam, via de regra, por todas elas, os prêmios mensais de operários da mesma linha em geral não diferiam mais do que de cem cruzeiros. Nas linhas 1 e 2 variavam ao redor de 750 cruzeiros mensais e, na linha 3 ao

${ }^{32}$ Para as retíficas e mandriladeiras era de oito cruzeiros por cem peças, mas essa percentagem maior não significava um prêmio total maior, pois a produção sendo em linha e havendo duas ou três daquelas máquinas por linha, enquanto um certo número de peças passa pelas outras máquinas, por elas passa um terço ou a metade desse número. Há, entretanto, claramente, maior prestígio, devido a essa diferença de prêmios, ligado ao trabalho nessas máquinas. redor de 400 cruzeiros, não sendo, em média, portanto, muito mais do que 20 por cento do salário mínimo. Usualmente, o operário era (como ainda é) admitido com o salário mínimo, sob a classificação de "serviços gerais" e ficava, por um período que podia variar de dias até meses, trabalhando em faxina ou na execução de uma ou outra operação manual nas peças. Somente então, passava para uma máquina e auferia o prêmio correspondente. Além do prêmio, os operadores de máquina tinham, em geral, um salário-hora pouco acima do salário mínimo.

No início de 1957, foi resolvido pela diretoria abolir o sistema de prêmios. A medida foi tomada embora houvesse entre os diretores desacordo sobre a questão. Enquanto um lado achava que a produtividade cairia com a abolição do sistema de prêmios, o outro acreditava que esta permaneceria a mesma. O sistema, alegava este último, era uma fonte de reclamações, além do que representava uma perda apreciável de tempo no escritório, com os registros e cálculos que se faziam necessários. Os que defendiam o sistema até então em vigor cederam, embora ponderassem que haveria dificuldades legais para voltar a instalar os prêmios, caso diminuísse a eficiência.

A mudança de sistema de pagamento foi efetuada da seguinte maneira: o prêmio mensal médio de cada operador de máquina foi calculado e convertido em cruzeiros por hora, quantia que foi então adicionada ao salário-hora base anterior. $\mathrm{O}$ resultado foi então geralmente arredondado para cima para a classe de salários mais próxima ${ }^{33}$.

Não há dados estatísticos que permitam aquilatar, com precisão, alguma mudança que porventura tenha ocorrido na produtividade com a supressão dos prêmios. Chefes e operários afirmam que esta não abaixou ou, se diminuiu, foi pouco. Entretanto, pelo que dizem, não tendo mais os

33 Foi estabelecida na mesma ocasião uma escala de salários conforme a categoria (qualificação) do operário. Assim há, acima do salário mínimo, "serviços gerais" (com 17 ou 19 cruzeiros por hora), ajudantes (com salário de 21 ou 23 cruzeiros por hora), meios-oficiais ( 25 ou 26 cruzeiros por hora), oficiais (27,50 ou 29 cruzeiros), pessoal categorizado (com salário individual) etc. Visou-se, com essa escala, disciplinar a política de salários. $\mathrm{O}$ empregado, ao adquirir maior experiência no serviço ou ao subir de categoria, passa de um salário para outro. 
operários preocupação com a produção (o que parece indicar que houve pelo menos uma pequena queda), melhorou a qualidade.

\section{Comportamento econômico e sua motivação nas comunidades de origem}

Considerando a descrição feita anteriormente das condições de trabalho nas comunidades rurais, donde veio a maioria do operários semiqualificados da fábrica, vê-se que lá, via de regra, o trabalho era executado como parte da vida familial e regulado por normas tradicionais. Mesmo para os procedentes daquelas regiões rurais, como o interior de São Paulo, onde é maior o grau de comercialização e individualização do comportamento econômico, a conduta no trabalho, as técnicas, a divisão de tarefas, o ritmo das atividades e a autoridade, quando comparados com os da economia urbana, têm ainda em boa dose um caráter nitidamente tradicional. Isto é ainda mais verdadeiro quando se trata de nordestinos pois, na grande maioria dos casos, tinham uma economia de subsistência. Por outro lado, deve-se acentuar que, quase sempre, mesmo no caso desses últimos, havia relações e atividades econômicas em que eram socialmente sancionados traços de utilitarismo e impessoalidade. Como, entretanto, o indivíduo trabalhava em geral com a sua família, com exceção daqueles que se dedicavam ao comércio ambulante rural ou ao urbano, somente eram impessoais e utilitárias as relações infrequientes com pessoas fora do círculo familiar (com o dono da terra, o comerciante etc.), uma vez que a organização da lida diária derivava das normas costumeiras do sistema de parentesco. Em outras palavras, a situação era a seguinte: a organização interna do trabalho no empreendimento econômico da família era contemplada por prescrições sociais derivadas da vida tradicional do grupo e as relações com elementos estranhos ao grupo de parentesco guiavam-se, de acordo com a expectativa social, pelos interesses individuais e pelos padrões racionais de ação. Mesmo neste último caso, a atuação desses interesses e padrões limitava-se, provavelmente, pelo costume e pelo aparecimento de relações pessoais, entre vendedor e comprador.

Resta mencionar os casos de operários que, antes de virem para São Paulo, viviam em pequenos centros urbanos (comunidades quase rurais) onde suas famílias tinham, em geral, modestos estabelecimentos comerciais (açougue, loja, barbearia etc.). Participavam, mesmo antes de se mudarem para a metrópole paulista, de uma vida econômica, que, embora ainda impregnada da atmosfera tradicional de uma sociedade de folk, já era nitidamente comercializada. As relações do comércio desses pequenos centros, comparadas com as da sociedade urbana, apresentam indubitavelmente bastante de costumeiro e primário, lado a lado com o elemento impessoal e utilitário, embora esses últimos fatores já sejam preponderantes.

\section{Ausência de padrões de ação coletiva}

$\mathrm{Na}$ análise dos fatores sociais que condicionam o trabalho dos operadores de máquina deve-se considerar: ausência de padrões de ação coletiva; influência da legislação trabalhista; e permanência de valores tradicionais na conduta do operário no trabalho.

É observação corrente entre mestres, contramestres etc. pessoas próximas dos operadores - que estes "não têm união". Com isto querem dizer que não há ação conjunta, mesmo referente a coisas sobre as quais os seus interesses coincidem e que, presumivelmente, seriam mais facilmente alcançadas pela ação coletiva. Notam mesmo que não é raro prejudicaremse mutuamente no afã de obter vantagens pessoais. A narração de tais casos, porém, é feita de forma a revelar a desaprovação de quem conta. Esta situação decorre do tipo de solidariedade que existe entre os operários. A base dessa solidariedade é apenas o seu conflito latente e vago com "os patrões". No caso de desacordo entre um operário e a firma, os seus companheiros, operários de nível de qualificação equivalente, ficam do seu lado. Isto não significa, entretanto, que façam alguma coisa para ajudá-lo. A ação organizada para defesa dos interesses do companheiro é quase inexistente. Limitam-se em geral a acompanhar o conflito com interesse, a expressar a sua satisfação quando o operário leva a melhor e a não prejudicá-lo (deixando de acusá-lo ao chefe ou de depor em juízo contra ele). Embora não seja muito comum, há casos também de operários que, arriscando a sua situação na firma, chegam a testemunhar a favor de colegas.

Antes de examinar mais detidamente o comportamento dos operários referente à produção, onde se verifica concretamente a ausência de padrões de ação coletiva, é preciso mencionar que, ao lado da natureza difusa da solidariedade, se nota, nas linhas de produção, inexistência de liderança clara entre os operadores de máquina. Certas operações, a das retíficas e das mandriladeiras, atribuem maior prestígio, embora o treinamento de operários não seja nelas muito mais longo ou difícil do que nas outras. E 
este fato talvez implique terem eles uma influência maior sobre os demais. Tais máquinas são geralmente operadas por pessoas que têm maior tempo de serviço na firma e gozam de maior liberdade no trabalho (saem maior número de vezes da máquina ou da seção, conversam mais etc.). Entretanto esse prestígio, essa maior influência, não chega a caracterizar uma liderança clara.

A organização informal das linhas de produção é melhor descrita como constando de uma série de pequenos grupos de amigos - amizade que se expressa em conversas durante o serviço, em caçoadas, brincadeiras de mão etc. e, às vezes, em convívio, fora do recinto da fábrica. Essas relações de amizade se formam, às vezes, pelo simples fato de as pessoas em questão terem por algum tempo trabalhado perto uma da outra, mas mais frequentemente por serem parentes ou conterrâneos, da mesma cidade ou do mesmo Estado. Tais grupos incluem apenas poucas pessoas, quatro ou cinco na maioria das vezes, nem todas da mesma seção e, portanto, não podem servir de base para uma ação que una todos de uma linha, muito menos todos da fábrica. No máximo, essas relações de amizade são utilizadas por um ou outro operário, que tem um "caso" com a firma e precisa de alguém que sirva de testemunha a seu favor.

O sindicato não penetra suficientemente fundo nas oficinas da fábrica de modo a poder influenciar o comportamento quotidiano do empregado. $\mathrm{O}$ sindicato é para esses operários, quase sempre, um meio de que se utilizam para fins econômicos individuais (aumento de salário, indenização, aviso prévio etc.), cuja consecução vem justamente, muitas vezes, possibilitar, como vimos neste trabalho, o abandono da condição de operário. A maioria entra no sindicato quando precisa dele, principalmente dos serviços de advogado (consultas particulares; processos contra o empregador). O modo como encara a organização sindical e a sua permanência como membro dependem do sucesso obtido pelo sindicato ao tratar dos seus "casos".

Uma firma em que R. F. estava, atrasava o pagamento e um grupo de operários parou de trabalhar, foi ao sindicato e abriu processo. "Foi aí, diz, que entrei no sindicato." Há dois anos deixou de ser sócio porque num outro caso que tiveram, foram ao sindicato "e eles (do sindicato) começaram com manha" e desistiram. "Não resolvia, demorava, agora está assim o sindicato."
J. J. assevera que o sindicato "é a melhor coisa que nós temos. A gente paga para ele menos que para o IAPI e o IAPI só atende o sujeito quando este está muito mal. No sindicato nós temos todos os direitos. Tem direito a médico, a farmácia e não paga nada. Tem barbeiro e paga quinze cruzeiros o cabelo. Tem advogado e não paga nada".

S. N.A. conta que entrou no sindicato de metalúrgicos em Santo André, mas que depois desistiu. "Quando precisei do sindicato, não encontrei; quem fez o que eu precisava foi o SESI." Tratava-se de uma sua filha que não tinha registro. No sindicato "diziam, vem amanhã e, depois eu ia no outro dia e o advogado não estava".

M. M. S. é sócio do sindicato. Narra com gosto os vários processos que ele e os seus colegas "abriram" contra a firma, uns com sucesso e outros não. A vez, por exemplo, que "o nosso advogado (advogado do sindicato) mandou na audiência o advogado da firma calar a boca".

O sindicato não é visto como algo feito por eles, mas por outros ${ }^{34}$ para eles. Quando mencionam o sindicato, os operários não usam o pronome "nós", mas sim "eles". Da mesma maneira como se utilizam do IAPI e do SESI, para obterem serviços, usam o sindicato e o avaliam conforme consideram ou não satisfatórios esses serviços.

O sindicato indicou nas fábricas, entre os operários que tinham maior interesse na organização e com ela mantinham contato mais constante, os seus "delegados". Esta posição é extra-oficial e pretende estabelecer um agente de ligação entre o sindicato e as fábricas. Na Companhia o delegado é D., que os empregados da firma chamam de "representante" do sindicato. A maioria não sabe explicar qual é exatamente a sua posição no sindicato; dizem que D. está a par dos direitos que eles têm, das leis que existem etc., pois vai sempre ao sindicato e por isso quando precisam de alguma informação recorrem a ele. Embora não haja dúvida que D. tem bastante influência entre os seus colegas na fábrica, esta deve-se mais ao fato de que esperam obter dele informações sobre os seus "direitos" do que de uma ${ }^{34}$ Identificam, implicitamente, o sindicato com o Governo, quando distinguem os aumentos
que são dados espontaneamente pela firma dos dados "por lei", incluindo nesses, tanto os
que resultam do estabelecimento de novos níveis de salário mínimo, como de contratos coletivos dos sindicatos. 
posição de liderança real. A sua posição na fábrica somente pode ser bem compreendida à luz da atitude, já descrita, dos operários para o sindicato. Vêem o sindicato como alguma coisa organizada para eles por outros. Eles se utilizam do sindicato para os seus fins particulares e, para isso, D. é o elemento de ligação. Alguém que lhes permite estar a par do que acontece na sede da organização, que os esclarece sobre leis etc. Informações essas que são recebidas com a mesma falta de confiança com que o são todas as comunicações ou afirmativas da Companhia ou do Governo. É como se dissessem: "eles dizem que... mas eu realmente não sei". Atitude compreensível quando nos lembramos que saíram de um mundo pequeno, familiar, de uma sociedade de folk, em que as relações eram pessoais, vindo para o mundo urbano, onde estão rodeados de instituições e grupos, distantes, impessoais, alheios, até onde podem ver, aos seus interesses.

Muitos criticam D., acham que ele realmente não sabe resolver os "casos" (se se tem direito a uma coisa ou outra) e que é ignorante. Um operário, quando D. se candidatou a um cargo na diretoria do sindicato, por ocasião da eleição de 1957, após pedir reserva, declarou que não votara nele, pois é uma pessoa "que letra escrita (manuscrita ao invés de impressa) tinha dificuldade de ler!"

D. sempre tem feito parte, desde o início da fábrica, da Comissão Interna de Prevenção de Acidentes (CIPA). A Comissão, que se compõe de seis representantes dos empregados da fábrica, três efetivos e três suplentes, e outros tantos da administração, além de discutir medidas de segurança, serve como órgão de debate de quaisquer queixas ou pedidos dos empregados à Companhia ou de comunicações desta àqueles. Por ocasião das eleições, D. é quem organiza a lista de candidatos, incluindo além do seu os nomes de cinco outros empregados. Nunca surgiu oposição. Os candidatos do "representante" do sindicato eram sempre eleitos. Na eleição de 1957 da CIPA, L. C., ou porque, como explicou, "queria ver por si mesmo se era possível fazer alguma coisa na CIPA", ou por que foi convencido a isso pela seção do pessoal, dirigiu-se a $\mathrm{D}$. e disse que queria ser candidato. D. respondeu-lhe "que nesta vez não (era) possível, porque a lista dos nomes já (estava) completa". L.C. não se conformando foi à seção do pessoal e, segundo conta, registrou o seu nome para a eleição. Apresentaram-se assim dessa vez sete candidatos para seis lugares. É interessante notar-se o fato de L. C. ter primeiro procurado D., o que mostra até certo ponto que os seus colegas de trabalho o aceitam como uma espécie de ligação entre eles e a diretoria. Isto é em parte decorrente de ter esta última muitas vezes usado D. para estabelecer contatos com os operários. A influência que possui D. é devida somente à ausência de outra pessoa que tivesse alcançado espontaneamente entre os operários uma posição de liderança. Os resultados da eleição mostram quão precária é a aceitação de D. pelos operários como seu representante j unto à administração. L. C., inscrito como candidato sem a aprovação de D., tirou o primeiro lugar e este, o terceiro, obtendo assim o último lugar entre os membros efetivos da comissão.

Estes fatos mostram que D., embora tenha algumas funções de liderança, como sejam transmitir à diretoria, quando solicitada, a opinião dos trabalhadores sobre um ponto ou outro, ou servir como fonte de informações sobre o sindicato, não pode ser considerado como representante dos operários. O papel desempenhado por D. demonstra claramente a natureza fragmentária da organização informal dos trabalhadores da fábrica. Esta organização consta, como já foi dito, de pequenos grupos baseados em lealdades primárias desenvolvidas na sociedade tradicional ou no meio industrial. Grupos esses, que não se interrelacionam através de líderes de turmas, seções etc., de forma a permitir, em certos casos, uma unidade de ação que englobe parte considerável dos operários da fábrica. De certa maneira, pode-se dizer que D. preenche as suas funções, sem ter ganho a confiança de muitos dos seus companheiros e com a indiferença de muitos outros, exclusivamente porque tem ligações com o sindicato e foi usado pela diretoria da Companhia como elemento de contato. Em certo sentido, ele é imposto de cima aos seus colegas. Isto é possível porque, devido à organização social rudimentar dos empregados, não surgiram outros líderes.

A consciência de estarem como operários da fábrica na mesma posição e constituírem um grupo, serve às vezes de base à ação comum, embora esta ação seja frágil. O grau e a natureza da solidariedade que os unem podem ser melhor esclarecidos por um relato do comportamento destes operários durante a greve declarada pelo sindicato em outubro de 1957. Os sindicatos de trabalhadores de várias categorias econômicas, quando as mesas redondas promovidas na Delegacia Regional do Trabalho (das quais eles participaram juntamente com os sindicatos patronais), não 
levaram a entendimentos, marcaram, através da Aliança Intersindical então formada, o início da greve para o dia 15 . Na Companhia, nas vésperas deste dia, muitos empregados davam a entender que não entrariam no serviço no dia seguinte "para evitar encrenca", pois os boatos eram que os "piquetes" de greve iriam impedir que trabalhassem.

A gente vem (até à porta da fábrica) para ver", disse F. A., "se encontra aquela turminha (piquete do sindicato), não entra". Daí a momentos acrescentou: "Acho que sai greve. A maioria (participa) para que não saia encrenca.

Alguns previam que se trabalharia na fábrica, pois em outras greves a administração entrara em entendimentos com os empregados; afirmavam que, na Companhia, os operários nunca aderiram a greves. Realmente, por duas vezes desde a fundação da Companhia, por ocasião de greve de todo o ramo industrial, lá não foram interrompidas as atividades, tendo a diretoria oferecido um aumento de salário, antecipando qualquer acordo a que posteriormente chegassem os sindicatos patronal e de trabalhadores. Desta feita, porém, declarou um dos diretores, havia boatos de que não haveria garantias policiais para as indústrias que quisessem funcionar e, por isso, não iriam tentar nenhum acordo com os seus empregados.

Ainda no dia 14, D., que fora eleito para a diretoria do sindicato e estava na fábrica no seu último dia de trabalho, antes de afastar-se durante os dois anos da duração do seu mandato, passou pelas oficinas para despedir-se de seus amigos.

Logo, grupos de operários formaram-se ao seu redor, querendo saber "se amanhã haveria greve". Ele explicava a um e a outro: "É, vai haver. Agora não tem mais jeito (não houve acordo). Se eu dissesse a vocês que não vai ter, estaria mentindo". E a outro grupo: "É melhor não virem (trabalhar). $\mathrm{O}$ que adianta meia dúzia querer trabalhar quando cem não querem? É melhor não virem..."

No dia do início da greve, com exceção dos mestres (chefes das várias linhas de produção etc.; todos estrangeiros), nenhum operário entrou na fábrica. $\mathrm{O}$ chefe da seção do pessoal e dois outros empregados de escritório de categoria vieram à fábrica na hora dos operários entrarem, para ver o que iria acontecer e tomar as medidas que se fizessem necessárias. Um desses narra que a maioria dos operários veio até à fábrica.
Estavam todos nas redondezas da fábrica, em pequenos grupos. Quando chegou a hora, mandaram tocar a sirena. Houve aquele movimento entre os operários, aquele zunzum, mas ninguém queria ser o primeiro a entrar. Ninguém entrou. Havia uni pequeno grupo de "piquetes" na esquina. Estavam observando uma pequena fábrica perto da nossa, onde estavam trabalhando. Não houve nenhuma demonstração, intimidação, nada.

Nos dias seguintes repetiu-se mais ou menos a mesma cena. Um número menor de operários ia até lá na hora da entrada e, depois de certificar-se de que ninguém entrara, retirava-se pouco a pouco, Nos primeiros três dias de greve, segundo os jornais e a opinião geral, não houve policiamento suficiente e as depredações multiplicaram-se ${ }^{35}$. No quarto dia, na sexta-feira, tornou-se pública uma declaração do Governador no sentido de que, depois de uma determinada hora, a Polícia e a força Pública agiriam com a máxima severidade a fim de manter a ordem na cidade deste momento em diante, o policiamento foi ostensivo. Como nos sábados apenas uma pequena parcela dos empregados trabalha na fábrica, a segunda-feira foi o dia no qual se pôde verificar se o policiamento havia alterado ou não a disposição dos operários de não entrarem em serviço.

Nesse dia, minutos antes da hora de início do trabalho, podia-se ver os operários da Companhia aglomerados nas esquinas. Conversavam em pequenos grupos, sem grande barulho, parados, observando os portões de entrada. Um soldado da Força Pública passou entre eles afirmando a um e a outro que poderiam entrar, que "teriam proteção". Afastou-se e todos continuaram a esperar, olhando na direção da fábrica. Tocou a sirena. A porta estavam dois milicianos da Força Pública e dois ou três guardas da Companhia. Como os operários não entraram, fecharam os portões e deixaram apenas uma pequena porta aberta. Lentamente foram-se desfazendo nas imediações da fábrica os pequenos grupos de trabalhadores. As últimas aglomerações foram dispersadas por alguns cavalarianos.

Informaram alguns operários que enquanto estavam lá viram entrar no serviço somente três ou quatro empregados. (É interessante notar que,

\footnotetext{
${ }^{35}$ Não se pretende aqui analisar a greve como um fenômeno global (ação do sindicato, pressões políticas etc.), mas somente como se comportaram os empregados da fábrica em estudo durante a greve.
} 
quando contam os que quebraram a greve, referem-se apenas aos que são das oficinas, com a exceção dos mestres, que são estrangeiros; estes entraram no trabalho ${ }^{36}$.) Falando dos que entraram na fábrica, um operário usou o termo "fresquinhos". Outro comentou que só entraram "os novos de casa". Um terceiro, à pergunta; de se fariam alguma coisa aos que tinham ido trabalhar, respondeu que não e se justificou assim: "Não podem nos prejudicar... três não tocam uma linha!"

Alguns, embora também demonstrassem hostilidade contra os que tinham "furado" a greve, expressaram a opinião de que "esta não era a hora de se fazer greve, principalmente depois dos gastos (que tiveram) com a asiática" (a grande maioria dos trabalhadores esteve acamada durante a epidemia de gripe asiática, que assolou a cidade em setembro daquele ano) ou então confessaram-se desconfiados de que "a greve (tinha) qualquer coisa atrás", perguntando: "por que eles (donos da Companhia) não quiseram entrar em acordo? Se não ofereceram nada, é porque não têm pedidos para entregar, têm estoques..." Outro contou que ouvira pelo rádio que "era coisa política, que os industriais desejavam a greve, que tinham estoques", e acrescentou: "quem perde somos nós, os coitados!"

Muitos operários vieram aquela segunda-feira à fábrica pensando ou esperando que o grupo todo resolvesse entrar no serviço. "Saí de casa, confessou um deles, pensando que hoje entrariam, mas eu disse à minha mulher, se (os outros) não entrarem, eu também não entro!" As condições para recomeçarem o trabalho naquele dia eram mais propícias do que nos anteriores por dois motivos: sendo o primeiro dia da semana, não tinham ainda perdido o domingo remunerado, o que aconteceria depois de faltarem uma vez, e, em segundo lugar, porque na sexta-feira anterior fora o dia em que seriam recebidos os vales, o que quase todos nas oficinas fazem costumeiramente nos meados do mês, e o chefe do pessoal havia dito aos que vieram descontar vales, que somente pagaria se voltas sem ao trabalho. Um operário qualificado, desaprovando "não terem entrado" na segundafeira, comentou: "Quero ver depois muita gente, sem dinheiro, arrependida!"

\footnotetext{
${ }^{36} \mathrm{Na}$ realidade, compareceram naquele dia às oficinas, além dos mestres, segundo dados da seção do pessoal, 28 empregados, dos quais, porém, mais da metade eram operários qualificados e contramestres, quase todos estrangeiros.
}

No dia seguinte, terça-feira, muitos entraram no serviço; segundo um empregado de categoria da administração, todos os que vieram até à fábrica. Duas horas depois de iniciado o trabalho, D., e outro membro da diretoria do sindicato de trabalhadores, chegaram e disseram aos donos da fábrica que houvera "denúncia" de que lá estavam trabalhando e pediram para "fechar a fábrica", evitando assim que o sindicato mandasse "piquetes" para lá. A isto se recusaram os diretores da fábrica, mas deram permissão a D. para percorrer as oficinas e falar com os operários. Ele o fez e todos saíram. Nos dois dias seguintes, quarta e quinta-feira, nenhum operário entrou no serviço. Nesse último dia, 24 de outubro, o Tribunal Regional do Trabalho decidiu pela concessão de 25 por cento de aumento aos trabalhadores, e a greve, nove dias depois do seu início, terminou ${ }^{37}$.

Se se indagarem dos motivos que levaram os operários da Companhia a participar da greve, ter-se-á de concluir que foi essencialmente uma combinação do receio de sanções por parte dos operários não pertencentes à fábrica, com o vago sentimento de solidariedade aos colegas de trabalho, ao grupo operário da fábrica. Estes fatores sofreram modificações no decorrer dos dias e exigem um exame mais detido. As afirmações, feitas antes do início da greve e no seu desenrolar, de que não viriam ou não vinham trabalhar "para evitar barulho" referiam-se sempre a conflito com "gente do sindicato"; são estes os que declaram e organizam greves; os operários desta como de outras fábricas têm um papel apenas passivo. Note-se, por exemplo, o fato de, na véspera do dia marcado para a deflagração da greve, irem informar-se com D., que pertence à diretoria do sindicato, "se iria haver greve". Mas, podiase sentir, mesmo então, que a explicação de não trabalharem porque a isso eram obrigados não era suficiente, salvo para uma minoria de trabalhadores qualificados e supervisores. Sentia-se que a alegação de não virem trabalhar para evitar "encrenca" era, em parte, uma desculpa que davam aos seus chefes para participarem do movimento grevista. Num dos dias da greve, por exemplo, um dos mestres, minutos depois de iniciado o trabalho, parou

37 Alguns dos sindicatos patronais recorreram desta decisão ao Tribunal Superior do Trabalho, que, em janeiro de 1958, a modificou, concedendo apenas 18 por cento de aumento. A aliança intersindical dos trabalhadores, depois de ameaças de nova greve, decidiu continuar os entendimentos com a Federação das Indústrias e com os empregadores diretamente. 
perto de um dos grupos de operários e em tom amigável perguntou: "Então, como vai isto?" Um deles, como quem se justifica, comentou: "Os guardas disseram que garantiam a entrada, mas quem garante a saída?" Mesmo no primeiro dia da greve, ninguém procurou entrar no serviço, apesar do "piquete" que compareceu ao local ter se mantido à distância, quieto, sem manifestações. Nos dois dias que se seguiram, às notícias que circulavam em toda a cidade pelos jornais e de boca em boca sobre violências praticadas para impedir o trabalho, tornam razoável supor que o medo de "encrencas" era então o principal motivo para não comparecerem ao serviço. Entretanto, na segunda-feira, pouquíssimos operários furaram a greve, mesmo quando o policiamento garantia, como era patente pela presença de guardas da Força Pública às portas da fábrica, a não utilização de coação física pelos "piquetes" que, nesse dia, por sinal, não apareceram nas cercanias da Companhia. Muitos operários, senão a maioria, individualmente, estavam dispostos a trabalhar, mas somente "se a turma entrasse". Não era bem, como um empregado da administração explicou, que "ninguém queria ser o primeiro a entrar", pois alguns entraram, mas estes eram identificados como elementos especialmente ligados aos chefes, ou como novos empregados e interessados em dar uma boa impressão, mas é que não entrara nenhuma parcela considerável dos operários da fundição e das linhas. Esta disposição dos membros do grupo operário da fábrica de agir como uma unidade é que leva à consideração de que, em certo grau, embora fraco, existe uma solidariedade, acima das relações particulares entre parentes, conterrâneos e amigos, pelo simples fato de serem todos operários e colegas de trabalho. Esta solidariedade entretanto é extremamente tênue, frágil e inarticulada. É a ausência de qualquer organização que resultou na visível hesitação dos operários de como agir e na situação paradoxal pela qual, embora talvez a maioria estivesse disposta a trabalhar se o "grupo" quisesse, no entanto, quase ninguém entrara em serviço. Praticamente, "verificaram" qual era a vontade grupal entreolhando-se e procurando sentir a intenção dos outros. Para chegarem a uma ação conjunta, não houve nenhum processo geral de comunicação entre eles; não houve discussões, nem debates; não surgiram líderes que representassem o ponto de vista do sindicato ou a oposição a este. A troca de opiniões que ocorreu durante esses dias de greve foi irregular e sem organização formal; deu se entre operários que moram vizinhos ou que, sendo parentes ou amigos, se visitaram no entretempo ou ainda, de manhã, nos grupos que todos os dias se formavam nas proximidades da fábrica, aí esperando para ver "se iam ou não" reiniciar o trabalho.

Convém além disso notar que essa solidariedade, sendo vaga e informe, não tinha como seria de esperar, na falta de um processo geral de discussão grupal, alvo bem definido. Havia muito pouca conversa sobre as razões da greve. O objetivo a ser alcançado de qualquer modo é assunto que, no seu entendimento tácito, não compete a eles mas sim ao "sindicato" decidir. Salvo a repetição de boatos sobre quanto "haviam" pedido de aumento ou quanto os patrões estavam dispostos a oferecer, quando se tocava no assunto era para se fazerem referências pouco explícitas a propósitos políticos que existiriam por detrás da greve ou ao interesse que nela presumivelmente teriam os industriais etc. É de notar que, tendo como finalidade a obtenção de aumento salarial, quase não houve preocupação em se discutir qual seria em cifras, feitas as devidas compensações, o aumento para os empregados da Companhia. Não deixa de ser expressivo o fato de terem os 25 por cento concedidos pelo Tribunal Regional do Trabalho, e considerados pelos sindicatos dos trabalhadores como uma vitória, resultado para grande proporção desses operários em nenhum ou em mínimo aumento de seus ordenados, por força da elevação de salários proporcionada espontaneamente antes do dissídio.

A solidariedade dos operários da fábrica, portanto, reduz-se, em última análise, ao mínimo denominador de toda a solidariedade - o sentimento de pertencer a um grupo que se coloca contra outro. Não há dúvida que existe um sentimento difuso de solidariedade dos operários contra os empregadores.

A. P., um cearense, conta que em Santos, onde foi carregador, certa vez fizeram uma greve que durou um mês, durante a qual o sindicato forneceu mantimentos para os operários casados. Não deixaram ninguém entrar na fábrica, "tudo combinado, tudo de acordo". "Aqui o sindicato não adianta nada. Fizeram uma greve... foi só um dia! Que adianta? Um mês sim, a firma abaixa mesmo."

É geral o modo de sentir do operário que, a propósito de uma modificação na fábrica contemplada pela administração comentou: - "O benefício é deles (donos), dos trabalhadores nunca é”. Exemplos como esses revelam, sem dúvida, um sentimento de antagonismo, uma 
consciência de uma situação comum dos que trabalham, em contraposição à dos ricos, "tubarões", donos de fábrica ou "capitalistas". Mas, o grupo abrangido pelo sentimento de solidariedade é o dos "trabalhadores", símbolo impreciso que não inclui apenas os operários, mas "os pobres", os que precisam de "trabalhar de dia para comer de noite". O que está surgindo entre esses operários de origem rural não é ainda a consciência de serem indivíduos numa situação nova (a de trabalhador industrial), que os distingue da de outros grupos da população, mas sim um sentimento de revolta da classe baixa (pobres, povo) contra as classes superiores, que não distingue operários, pessoas em ocupações urbanas modestas e meeiros, camaradas, pequenos sitiantes, no campo. Sentimento do qual podem participar, portanto, pessoas que, como foi visto na parte anterior deste trabalho, não estão completamente integradas, nem subjetiva, nem objetivamente, no meio industrial, mas que alternam ocupações agrícolas, comerciais e industriais, de classe baixa.

Essa solidariedade, ainda mais, além de ser fraca, não se expressa em ações formalmente organizadas que envolvam todo o grupo. Em outras palavras, não se traduz em ações das quais os operários em geral participem, independentemente das relações pessoais de amizade ou de parentesco que os una. Não há dúvida que na fábrica agrupamentos baseados nesses últimos tipos de relações se formaram. $\mathrm{O}$ que não existe são fenômenos tais como liderança com maior amplitude do que a daqueles grupos, formação de comissões que representem os operários perante a administração, ou simplesmente o costume de debate de questões de interesse geral etc. Quando há alguma coisa desse tipo, como é o caso da Comissão Interna de Prevenção de Acidentes, ela não surgiu espontaneamente entre os trabalhadores, mas foi imposta de cima, pela legislação ou por determinação da diretoria da fábrica.

Sendo assim, depois de desaparecida a ameaça de represália pelos "piquetes", a efêmera ação conjunta mantida na segunda-feira da greve, como já foi relatado, fragmentou-se. Número apreciável de operários foi então trabalhar no dia seguinte, impelido pelos seus motivos particulares, para receber vale, ou para não ser descontado um dia a mais, ou ainda para ficar nas boas graças do chefe.

Passando para a consideração dos fatores que enfraquecem a solidariedade desses operários brasileiros e tornam difícil o seu eventual fortalecimento, é preciso indicar a animosidade latente que existe contra os trabalhadores vindos do Nordeste, entre os outros ${ }^{38}$. Sem querer analisar aqui a sua origem, apontando tão-somente de passagem a provável relação com o aumento de competição econômica, o que é importante na questão em exame é o recrudescimento em São Paulo do preconceito contra o nordestino. Há muitas indicações deste fato é significativa, por exemplo, a crescente nitidez de estereótipo do "nortista", como também o foi a recente onda de "piadas de baianos" - e ele se encontra expresso em muitas das entrevistas. Um operador de máquina do interior de São Paulo referiu-se assim sobre os nordestinos na fábrica:

São brasileiros como nós... mas não vai! No início são uns carneiros, mas depois de um ano, quando têm direito a férias e a indenização, ou mesmo antes de um ano, não querem saber de mais nada. furo..."

E imitando-os: "Porque eu não tenho nada com isso, porque eu

Mais importante, entretanto, é o ambiente social de origem da maioria desses trabalhadores. Conhecendo-o, não deveria surpreender a ausência de padrões de ação organizada no grupo e o baixo nível da sua solidariedade. Nas comunidades rurais donde vieram, a oportunidade de participação em ação coletiva que existe é na base de laços de parentesco e de vizinhança, regidos sempre por normas tradicionais. Formas de cooperação de maior âmbito, envolvendo pessoas que não sejam parentes ou vizinhas, como há no mundo rural de outros países, são no nosso quase inexistentes. Mesmo o mutirão, que é uma forma costumeira de auxílio mútuo que pelo menos alarga a ação coletiva para além dos limites da família, desapareceu ou está em vias de desaparecer na maior parte do território nacional. Nada na sua experiência anterior à migração para a indústria da grande cidade prepara essa gente, ligada entre si apenas por achar-se em condições semelhantes de emprego em uma mesma empresa, a fim de participar junta de uma ação coletiva para a qual os padrões tradicionais de comportamento não lhe podem servir de guia.

${ }^{38}$ Levando-se em conta apenas os operários brasileiros que são os que interessam a este trabalho, é importante também a influência das relações de brancos e pretos sobre a solidariedade operária. Na Companhia, no entanto, empregados de cor são praticamente inexistentes. 
Era preciso fazer essa longa digressão sobre a coesão social do grupo de operários semiqualificados da fábrica e a espécie de organização que possui, antes de poder examinar o seu comportamento em relação à produção. A conclusão geral a que se chega é que, na situação, não pode existir controle social, relativo a esse comportamento, emanado dos trabalhadores, da fábrica ou de qualquer de suas seções, como grupo. A sua organização é muito rudimentar e a sua coesão muito fraca para isso. Não sendo o ritmo de trabalho do operário controlado de forma clara e inequívoca pelos seus companheiros de turma, restam apenas dois outros fatores cuja influência se faz sentir nele e que precisam ser analisados: de um lado, o controle exercido por valores sociais que foram internalizados pelo trabalhador e que, mesmo na ausência dos grupos que os mantinham, continuam a dominar a sua conduta, e, de outro, o controle exercido pelos seus "interesses" individuais, como ele os vê na situação em que se encontra.

\section{Influência de padrões e valores tradicionais relativos ao trabalho}

O primeiro fator indicado significa, em outras palavras, a influência entre esses trabalhadores de valores e padrões tradicionais trazidos das suas comunidades de origem. Perceber tais valores e julgar a sua importância para a produção não é tarefa fácil, não só porque são apenas subentendidos, não expressos, mas também porque provavelmente apresentam variações, dependendo das subculturas sob as quais esses operários viviam, antes da migração. Da situação, em que valores diferentes relativos ao trabalho se chocam e em que se está longe das sanções comunais que os apoiavam, decorre encontrarem-se nas oficinas, de um lado, pessoas que obedecem estritamente às expectativas tradicionais sobre o trabalho, com os deveres e direitos a ele inerentes, e, de outro, operários que, no meio industrial, desenvolveram um modo individualista de comportamento, em que a norma não é seguir determinados preceitos de conduta, mas utilizar-se das circunstâncias para em cada momento agir conforme o próprio interesse. Em outras palavras, sob a ação desagregadora das novas condições de vida e de trabalho, encontram-se os mais diversos graus de individualização da conduta.

Embora seja difícil aquilatar a importância da permanência de valores tradicionais que sirvam para explicar a produtividade dessa mão-de-obra de origem rural, a ocorrência em si do fato é clara. Transparece, por exemplo, quando se referem ao seu trabalho usando os termos "cumprir a obrigação", querendo com isso indicar não as funções explicitamente estabelecidas como inerentes ao emprego, mas sim o que é tradicionalmente subentendido como deveres do empregado; transparece também na valorização do "homem trabalhador", "pé-de-boi", e na desvalorização do "largado". Comentando aprovativamente o modo de um dos diretores da firma tratar os empregados, um operário acrescenta:

Tem gente malandro também. Que fica provocando. Quando ele (o diretor) vê que o camarada é vagabundo e não quer trabalhar, ele também não pode ser bom para uma pessoa assim, não é?

\section{Comenta outro:}

Os donos da Companhia são bons. Já vi isto. É claro que alguns (operários) ficam olhando para o ar. A gente precisa se ajudar, senão os outros não ajudam a gente. A gente não deve fazer demais. Isto é puxar saco, mas precisa se ajudar..

Um dos operadores mais esforçados da linha de produção, pessoa que raramente conversa, ou interrompe o serviço, é chamado pelos seus colegas de "lavrador". Diz ele:

O operário quando se interessa pelo serviço, o patrão também se interessa pela gente. De modo que nunca se pode diminuir a produção, tem que sempre aumentar... Tem uns operários que arrelaxam, dizendo que ganham pouco, uma coisa ou outra, e já diminuem a produção. O operário que é bom produz sempre normal. Nunca arrelaxa, nem de um lado, nem do outro.

Vê-se, neste caso, não só o autocontrole derivado da internalização de expectativas sociais da comunidade original, como também, no tom de caçoada dos companheiros que o chamam de "lavrador", a desaprovação do trabalho muito intenso.

Segundo a concepção tradicional da relação de emprego, tem-se a "obrigação" de executar o trabalho justo, mediante retribuição pelo patrão também justa. A noção do que é justo, num caso como no outro, deriva necessariamente do que é costumeiro e é, por sua natureza, imprecisa. $\mathrm{O}$ bom trabalhador é aquele que, segundo o consenso social, trabalha num nível de dedicação que tradicionalmente é considerado bom. Há, em geral, 
também, limite superior dos esforços que devem ser despendidos: "A gente não deve se matar". A natureza mesma desses valores tradicionais, pela dependência em que estão de um consenso grupal, em que as obrigações e direitos recíprocos das classes superior e inferior a que pertencem patrões e empregados se acham regulados pela tradição, torna impossível a sua permanência no ambiente urbano-industrial, no qual aquele consenso deixa de existir. Nesta situação, os indivíduos se vêem obrigados a usar critérios pessoais do que é justo (e então, no dizer do operário há pouco citado, quando julgam "que ganham pouco, já diminuem a produção") ou a controlar o seu comportamento por normas racionais, agindo não segundo preceitos substantivos tradicionais, mas da maneira mais vantajosa para os seus interesses.

Sente-se também a aplicação de atitudes costumeiras em novas circunstâncias no modo como encaram a legislação trabalhista, principalmente o direito à indenização no caso de dispensa. Vêem "os anos que têm de casa" como o "seu direito" a tantos salários, independentemente de ter sido justa ou não a dispensa. Mencionam os anos de serviço que têm na firma como um pecúlio acumulado - ao que, muitas vezes, na prática, de fato equivalem - e propõem às vezes "acordos", à firma, para saírem recebendo parte da indenização a que teriam direito se fossem despedidos sem justa causa. Enquanto tais propostas são vistas por representantes da administração da empresa como ameaça do trabalhador de, caso o acordo não seja feito, diminuir a sua eficiência, esse último, muito mais frequentemente, as concebe como um trato "justo", pois os anos que tem na firma the conferem o direito àquele número de salários.

Tacitamente, a pressuposição é que a legislação trabalhista, ao invés de ser um corpo de normas impessoais válidas universalmente, constitui ao contrário os "direitos" dados pelo Governo a um grupo determinado da população - o operário ${ }^{39}$. Esta noção é compatível com a atitude generalizada, de caráter quase filial, de esperar do Governo a solução de

${ }^{39}$ Este é um exemplo do que parece ser um dos pressupostos sociais básicos da sociedade brasileira; o de conferirem muitas vezes as leis, direitos a grupos sociais específicos, ao invés de serem esses direitos inerentes a determinadas posições, sem consideração da origem social das pessoas que nelas estão. Embora, na sua forma, elas aqui tenham este último caráter, na realidade são frequentemente influenciadas pelo espírito de atribuir privilégios a grupos de status. todos os problemas nacionais. Um nordestino, por exemplo, veemente mente asseverou que, desde a Independência, o Governo brasileiro vem deixando de resolver os problemas do povo.

Por que deixa crescer uma parte do País nesta desproporção? Os Poderes (as autoridades) não deveriam deixar crescer assim um país (São Paulo) dentro de um Estado e provocar esta vinda deste povo todo do Norte. Deveria ter proibido a continuação de formação de indústrias em São Paulo e dizer: você vai e faz esta indústria em Minas, você faz ali, você lá... E aqui na cidade de São Paulo? Os Poderes deveriam (para resolver o problema do transporte) obrigar as indústrias a irem para fora...

Para mostrar o papel do Governo fez a analogia: "É como quando o pai é bom, os filhos também são. Acho que quem tem culpa é o Governo e não o povo!"

Da mesma maneira espera-se que o Governo impeça a elevação do custo de vida, determine aumentos de salário, dê os direitos dos operários e os garanta. (Atitude que - aponte-se de passagem - é coerente com a relativa passividade do trabalhador quanto a ele próprio reivindicar em ação coletiva aqueles objetivos.) Essas expectativas em relação ao Governo decorrem das pressuposições da organização tradicional da sociedade brasileira: que esta constava de uma hierarquia de grupos, cada um com obrigações e direitos próprios, na distribuição dos quais o Governo (realmente, as classes dominantes) tinha papel predominante. É a ordem de idéias que se reflete nas palavras do operário quando, tratando de indenização, salário etc., fala em "reclamar os seus direitos!"

\section{Comportamento racional no trabalho}

É indubitável e generalizada, portanto, a influência de valores e da organização tradicional no comportamento do operário que tem a zona rural por origem. Entretanto no meio industrial, dentro do arcabouço constituído por esses elementos costumeiros, atuam padrões de conduta individualistas e racionais. Em larga medida, o trabalhador age guiado pelos próprios interesses. Entretanto, isto não significa, está claro, que essa ação não seja socialmente condicionada. $\mathrm{O}$ modo pelo qual vê os seus interesses e a maneira pela qual procura cuidar dos mesmos dependem de crenças e valores que não se desenvolveram sozinhos, mas sob a influência das 
tradições do seu meio rural e na troca de impressões na cidade com outros colocados em posição semelhante à sua.

Realmente, normas de comportamento racionais e individualistas não são desconhecidas nas comunidades rurais, nem mesmo nas mais isoladas. É comum, como se viu, mesmo em famílias do Nordeste empenhadas numa agricultura de subsistência, a prática, por um ou outro membro, de atividades de comércio em pequena escala. Esta ocupação proporciona-lhes, pois, familiaridade com aqueles padrões. A mudança que sofrem na sua vida econômica, embora enorme, é em última análise uma questão de alargamento do campo de atuação daqueles padrões no seu comportamento. O que lá no meio rural era acidental e esporádico, torna-se aqui a base de sua existência econômica.

Por outro lado, a aplicação daqueles critérios também é moldada pelo modo por que, no processo de interação no meio operário paulista, é definida, sob a influência da imprensa, do rádio, da propaganda política etc., a relevância para os seus interesses de fenômenos novos na sua experiência, como o são os sindicatos, as leis trabalhistas, a Justiça do Trabalho e os institutos de assistência social.

Somente examinando a sua conduta na fábrica no referente à produção, pode-se ver como o operário compreende o seu interesse e que medidas toma para satisfazê-lo. É opinião generalizada tanto entre pessoas da administração, como entre supervisores e operários que, depois de alguns anos de casa, o trabalhador diminui a produtividade, a fim de receber os "seus direitos" (indenização). Este comportamento, embora com exceções, é comum. Por outro lado, queixam-se os operários de que, quando ficam antigos no emprego, a firma começa a "castigá-los", dando aumento aos mais novos e não a eles, sendo menos tolerante com eles no que concerne a atrasos, justificação de faltas etc. Diz um operário que está na Companhia há mais de quatro anos:

Nunca pedi aumento. Não gosto de dar o braço a. torcer e faço a mesma produção que os outros. O empregado vai ficando velho na firma e eles começam a castigar devagarzinho, que é para o empregado se enfezar e pedir as contas e eles não precisam pagar os direitos.

E explica:
Às vezes, o senhor é novo na casa e eu sou velho. Vem aumento para o senhor e não para mim. Eu não penso e posso sair. É assim que eles castigam. Eu não sou mau elemento, mas também aumento eles não me dão... A gente chega um minuto atrasado e já descontam o domingo.

Os dois fatos são mutuamente dependentes. Sendo generalizadas ambas as idéias, qualquer "injustiça", real ou imaginária, da Companhia ou do chefe, desperta o desejo no operário de ser dispensado para receber indenização. Do seu lado, os chefes das oficinas, crendo na ineficiência de todos os subordinados muito antigos, tendem, no caso de operários não ou semiqualificados, que são facilmente substituíveis, mesmo quando ainda não há nenhum sinal de desídia, a não recomendar aumentos e a serem mais rigorosos na disciplina.

É necessário examinar mais de perto as circunstâncias que podem modificar esse fato. Primeiro, os operários das linhas de produção estão conscientes de que, em geral, na Companhia recebem mais do que ganhariam se tivessem de entrar noutra firma, pois, não tendo qualificações, seriam admitidos com salário mínimo 40. Eles somente começam a achar, portanto, que vale a pena diminuir a produção para serem despedidos e receber indenização quando se sentem prejudicados, brigam etc. ou quando, tendo vários anos de casa (cinco ou mais dependendo, entre outras coisas, das suas ambições), pensam que com a indenização poderiam fazer alguma coisa por conta própria. (A atuação neste ponto dos valores tradicionais ligados à “independência econômica" foi já analisada na parte inicial deste estudo 41.)

Outro fator na situação é a possibilidade de o chefe do operário poder evitar que ele prejudique o andamento do serviço da seção e, passando ao contra-ataque, poder "castigá-lo". Os operadores das linhas encontram, devido à pouca qualificação, dificuldades, se querem “amarrar” a produção. Mesmo nas operações mais difíceis, na retífica e na mandriladeira, um novo operário pode ser nelas rapidamente treinado, em quinze dias no máximo. Como há sempre gente, em outros serviços, considerados menos importantes e menos remunerados, que quer ter oportunidade de trabalhar em máquinas, pode um operário que começa á restringir a sua produção ser

${ }^{40} \mathrm{O}$ que é relevante neste ponto não é o fato em si, que, aliás, parece verdadeiro, mas a crença dos empregados de que essa é a situação.

${ }^{41}$ Ver acima, p. 39-42. 
tirado da linha pelo chefe e colocado num dos serviços sem prestígio da seção e outro ser treinado na sua máquina. Que isto acontece sem haver recusa do trabalhador substituto ou qualquer reação do grupo é novo indício do baixo nível de coesão grupal. Um controlador narra que um operário de uma das máquinas da linha de produção começou a diminuir a sua eficiência porque não queria trabalhar horas extraordinárias.

Puseram ele num serviço sem importância. Tirar rebarbas e coisas destas. Para o chefe da seção é muito fácil fazer isto porque sempre tem uns que querem trabalhar nas máquinas. Isto porque (o que é substituído) não tem ofício definido e é fácil colocar fazendo outra coisa. Um torneiro teriam de mandar embora. Não podem colocar tirando rebarba. A mim igualmente não poderiam (pois na sua caderneta de trabalho está anotado que é controlador); a mim teriam de mandar embora.

Esta substituição, como se vê, somente é possível quando na carteira do operário não está especificada uma ocupação definida ("torneiro" ou "retificador" por exemplo), pois então por lei não lhe podem mudar o serviço sem o seu consentimento, mas está anotado "serviços gerais" ou "ajudante".

Muitas vezes, operários, que podem ser substituídos e, portanto, são incapazes de "forçar" a sua dispensa pela diminuição de produção, pela recusa a trabalhar horas extraordinárias ou mesmo por meio de sabotagem (quebra proposital de máquina ou de ferramenta), pedem ao seu chefe, nas ocasiões em que, devido à falta de serviço, este precisa recomendar à administração o "corte" de alguns na sua seção, para incluí-lo entre esses ${ }^{42}$.

Na primeira hipótese, entretanto, em que o operário está "amarrando" a produção e não pode ser substituído, como é o caso dos operários qualificados, resulta um conflito entre o chefe e o operário que pode durar semanas ou mesmo meses e em face do qual os seus companheiros ficam passivamente como simples espectadores, acompanhando com interesse os acontecimentos. Um exemplo é narrado por um colega:

$\mathrm{Na}$ nossa linha tem duas retíficas. Numa um alagoano fazia 600, 500 peças por dia. Agora, depois de tirarem os prêmios, para se mostrar ou não sei porque, começou a produzir mais; chega a 700 ou mais. $\mathrm{O}$

${ }^{42}$ Ver o caso de A. S., p. 40. da outra, o V., não sei se pelo outro estar fazendo mais ou se para obter aumento (e operador nenhum da linha ganha igual a ele, que ganha 27,50 cruzeiros por hora), começou a amarrar a produção. Isto já faz um mês mais ou menos. Ele que tinha uma base de 800 para cima, agora faz 650, 700. O H. (mestre da linha) ontem chamou ele na cabeça. Ele saiu da máquina e foi conversar com o H. Ficaram lá uma hora . Diz que ele pediu aumento; que disse mesmo para o mandarem embora, pois tem planos de fazer alguma coisa por conta própria.

Um outro operário, mais chegado a V., explica que este está "amarrando" a produção porque acha que foi prejudicado por tirarem os prêmios; o aumento que lhe deram para substituir o que ganhava de prêmio não o satisfez.

Durante o tempo em que dura o conflito, o chefe tem "dores de cabeça". K., chefe da seção de manutenção, conta o caso de um soldador que está na Companhia há quatro anos e "agora não quer trabalhar".

Outro dia ele ficou a manhã inteira soldando uma coisa e ao meio-dia ainda não tinha feito. Alegando doença, que não estava se sentindo bem. O que ele quer é ser mandado embora para receber a indenização. A gerência está estudando o caso há quinze dias e não resolveu. E eles querem que o serviço de solda seja feito!

Na linha, por outro lado, "amarrar a produção" significa acúmulo de peças em certo ponto e a consequiente necessidade de trabalho extraordinário na operação cujo serviço se está atrasando. Para isso o chefe tem que arranjar alguém que saiba trabalhar na máquina em questão e esteja disposto a "fazer horas extras", pois o operário que quer ser despedido se recusa, é claro, a fazê-las. Quando são duas as máquinas que executam a mesma operação na linha, o atraso da produção numa delas pode significar a necessidade de o operador na outra aumentar a sua produção.

Diminuir a produção é comportamento que também ocorre com outros objetivos além de desejar ser dispensado, como sejam, querer trabalhar horas extraordinárias (a fim de auferir um pouco mais de salário) e querer ser mudado de máquina.

Às vezes um, conta um operário, que não gosta de uma máquina, trabalha menos para ser mudado. Eu não gostava da retífica, a gente tem de trabalhar com água e se resfria, mas não fazia isto; outros fazem. 
Os mestres das linhas de produção colocam deliberadamente na primeira máquina da linha operários que são "trabalhadores". Estes, produzindo muito, obrigam os outros da linha a acompanharem o ritmo, porque, do contrário, se acumulariam peças na sua máquina e "ficariam manjados" com o chefe (chamariam a atenção do chefe e ficariam conhecidos como maus operários). Operadores dão boa produção, "trabalham pisado", ou porque consideram isto a sua "obrigação" (ver pg. 61) ou, quando são novos no emprego, "para se fazer" (melhorarem a sua posição na fábrica). Os outros operadores que acompanham o passo dos primeiros da linha, o fazem porque não querem ficar "visados" pelo seu chefe, não só pelo que isto significaria para os seus interesses - pois, não gozando da boa vontade do chefe, não têm aumentos ou outras vantagens mas também porque, como falou um deles, "é sempre muito melhor trabalhar num lugar onde se está bem com todo o mundo, inclusive o chefe", com a atitude de subordinação espontânea, típica nas comunidades rurais.

O estratagema de colocar um operário esforçado para "puxar a fila" e marcar o ritmo de produção mostra novamente que longe estão de pensar os operários em agir coletivamente, no sentido de a linha manter um nível de produção definido grupalmente. É de notar que o ressentimento contra os que "trabalham pisado" é vago, individual e não organizado. Um ou outro operário que "tem raiva dele" pode vir a chamá-lo de "puxa-saco", mas longe dele, ou em tom de brincadeira, "para não zangá-lo". Estes operários esforçados não parecem ter dificuldades maiores que outros em fazer amizades e muito menos sofrem sanções sociais organizadas ou difusas por parte do grupo.

A situação, enquanto havia o sistema de prêmios de produção, era essencialmente a mesma. Havia, talvez devido ao incentivo monetário, um nível mais elevado de produtividade ${ }^{43}$, entretanto, isso não evitava que os modos típicos de se com portar, acima descritos, ocorressem. Quando o operário tinha vários anos de casa e "um ordenado compensador" (isto é, a indenização seria substancial) ele desejava ser despedido e o seu comportamento para atingir esse objetivo e os fatores condicionantes (poder ou não ser substituído etc.) eram os mesmos. A existência do prêmio não

${ }^{43}$ Ver p. $45-47$ fazia com que o operário, quando queria ser despedido, deixasse de “amarrar" a produção. Diz um trabalhador da linha: "era de apenas 800, 850 cruzeiros por mês; não fazia diferença". (O prêmio no início das atividades da firma, lá por 1950, era uma parte bem mais considerável do salário total do empregado; mas com a desvalorização da moeda e o aumento dos salários por hora, tendo permanecido o prêmio com os valores de três ou oito cruzeiros por cem peças, o total do prêmio ganho pelo indivíduo foi tornando-se com os anos, relativamente ao salário-base, muito menor.) Deve-se acrescentar, para a compreensão da falta de eficácia do prêmio como incentivo, que é crença geral que ele nunca era realmente calculado, mas que na seção do pessoal tinham "uma base" de quanto cada um devia ganhar, segundo era bom ou mau trabalhador, e pagavam de acordo com essa concepção. Alguns operários faziam as contas do prêmio que lhes era devido cada mês, registrando cuidadosamente a sua produção diária. Quando o total não coincidia com o valor pago pela Companhia faziam reclamações; outros não reclamavam, pois, sendo pequenas as diferenças, achavam que "não valia a pena fazer caso" e se indispor na fábrica.

Mesmo com o sistema de prêmios, havia animosidade entre uns operadores e outros que, "correndo muito", os obrigavam trabalhar também mais. Mas esses atritos eram individuais, como ficou já descrito, não havendo sanções grupais.

\section{Determinantes do controle grupal da produção}

As pesquisas sociológicas nas fábricas dos países industriais mais antigos, como a Inglaterra, os Estados Unidos e a França, têm mostrado com regularidade a existência do fenômeno de restrição de produção ${ }^{44}$. Foi ele observado sob vários métodos de pagamento, inclusive sistemas de prêmios por produção individual e grupal, refutando assim a pressuposição dos administradores de empresas econômicas de que o trabalhador guia o seu comportamento por normas inteiramente racionais. Em tais estudos, a restrição de produção revela-se como fenômeno grupal. As equipes de operários desenvolvem normas bem claras referentes ao nível de trabalho

${ }^{44}$ Ver, por exemplo, Roethlisberger, F. J. e Dickson, .W. J., Management and the Worker, Cambridge: Harvard University Press, 1939 e Roy, D., "Quota Restriction and Goldbricking in a Machine Shop", American Journal of Sociology, 1952, LVII, p. 427-442. 
que deve em várias condições ser mantido e sanções são por eles aplicadas aos que ultrapassam, ou às vezes também, aos que caem abaixo daquele nível. No estudo do Bank Wiring Observation Room, relatado por Roethlisberger e Dickson, estudo que é um dos mais cuidadosos, a interpretação dada pelos investigadores coloca a restrição de produção como resultante do processo social que ocorre dentro do grupo de trabalho, tendo como função a manutenção da organização social interna que aí espontaneamente se desenvolveu. Conseqüentemente, os autores daquela pesquisa rejeitam explicações que atribuem o fenômeno ao cálculo racional pelos trabalhadores, seja em termos de seus interesses econômicos a longo prazo (medo de desemprego ou de cortes de salário etc.), que contrabalançariam a diminuição de salário que resulta da restrição, seja para evitar atrair a atenção dos chefes para as atividades do grupo. As razões dadas pelos trabalhadores para a sua conduta (se produzirem mais do que fazem, "alguém será despedido", "os prêmios serão diminuídos" etc.), são tratadas pelos pesquisadores da Hawthorne como "racionalizações" dos sentimentos grupais originados na organização social da equipe de trabalho. Interpretações similares são adotadas na maioria das pesquisas que tocam o assunto.

Esta colocação do problema tem o mérito de salientar as influências do grupo de trabalho sobre a produtividade, ao invés de supor que esta decorre inteiramente da incidência das condições físicas ambientes e do sistema de salário sobre a conduta individual. Aquela interpretação, entretanto, é passível da crítica apontada por vários autores ${ }^{45}$, de que tende a ignorar determinantes históricos e estruturais que extravasam os limites do pequeno grupo de trabalho e mesmo os da empresa. Georges Friedmann ${ }^{46}$, por exemplo, aponta que a restrição de produção, mesmo quando não resulta da ação organizada dos operários através dos sindicatos, depende da sua experiência histórica coletiva, durante a flutuação do ciclo econômico e das mudanças tecnológicas características dos países capitalistas mais

${ }^{45}$ Ver, por exemplo, Bell, D., "Exploring Factory Life", Commentary, 1947, p. 79-88; Hart, C. W. M., "Industrial Relations Research and Social Theory", Canadian Journal of Economics and polítical Science, 1949, p. 53-73; e Sheppard, H. L., "The Treatment of Unionism in "Managerial Sociology", American Sociological Review, 1949, 14, no. 2, p. 310-313.

${ }^{46}$ Problèmes humains du machinisme industriel, Paris: Librairie Gallimard, 1946, p. 279283 e $301-323$. adiantados, com as resultantes despedidas de pessoal, cortes de salário, degradação de trabalhadores para serviços menos qualificados etc. Mesmo no caso, como, segundo Roethlisberger e Dickson, é o da Hawthorne, de a companhia não cortar prêmios de produção ou praticar quaisquer dos outros atos que os empregados receiam, isto não quer dizer que esses temores sejam completamente infundados e expressem pura e simplesmente sentimentos irracionais, cuja origem esteja na interação informal do grupo de trabalho. Os operários vivem em um ambiente industrial bem mais amplo que o da companhia onde no momento trabalham e neste ambiente tais práticas ocorreram e ocorrem, donde o aparecimento entre o operariado de crenças e atitudes, formadas pela experiência coletiva, que se tornam tradicionais. Embora, nos seus detalhes, as normas sociais dos trabalhadores referentes ao nível de produção, dependam da organização informal de cada grupo de trabalho, a prevalência dessas normas resulta justamente daquela experiência histórica; assim como também da organização sindical e das características gerais da estrutura industrial ${ }^{47}$.

Não se encontrou na Companhia organização informal do grupo operário capaz de exercer controle sobre a produção individual. Também não há participação em ação conjunta coordenada pelo sindicato e que tenha essa função de controle. Desta sorte a pesquisa realizada corrobora o ponto de vista de Friedmann de que a restrição de produção exercida pelo grupo operário é um fenômeno que só pode ser compreendido à luz do desenvolvimento da consciência de classe, das crenças e tradições do operariado, resultantes da experiência coletiva por que passa no meio industrial. Em uma região onde é recente a industrialização como São Paulo, onde os trabalhadores de origem rural, alternam o emprego na indústria com outras ocupações, não houve tempo nem condições para $o$ aparecimento daqueles fenômenos. Foi o que se procurou aqui documentar.

Os dados descritos podem ser encarados sob o ângulo da mobilidade social causada pela implantação da indústria. A mobilidade social é uma

${ }^{47}$ Mesmo nos países mais industrializados em que existe grau elevado de consciência de classe entre os trabalhadores, certas indústrias, como mostra pesquisa de Tom Lupton na Inglaterra, podem apresentar peculiaridades, decorrentes da sua situação competitiva no mercado, da atuação dos sindicatos etc., que resultam no não aparecimento de normas coletivas de controle da produção. Ver: "Social Factors Influencing Industrial Output", Man, 1956, LVI, p. 55-59. 
mudança de um status para outro de nível superior ou inferior. Com essa mudança de posição, o indivíduo vê-se envolvido em um processo de ajustamento a novas circunstâncias. Por outro lado, sem este ajustamento ou quando ele é insuficiente, a mudança de status é incompleta e instável.

Ao passar para operário, o habitante do mundo rural conserva muitos dos padrões de comportamento e dos valores relativos ao trabalho da sua comunidade original. Nesta, os critérios racionais e. individualistas regiam somente as relações econômicas com estranhos - com o comerciante, com o arrendador da terra e, quando o rurícola era também mascate, com os fregueses. $\mathrm{O}$ alargamento da atuação desses padrões de conduta e o valor atribuído à independência da atividade por conta própria, transferidos para o ambiente industrial, são fatores importantes na explicação da instabilidade do novo status.

Os operários estudados, vindos do campo, não se adaptam de maneira duradoura à estrutura industrial. Esta adaptação poderia ser obtida pela organização, para, através da luta coletiva, conseguirem a melhoria das suas condições como grupo, ou pelo aprendizado, que levaria à ascensão individual na hierarquia. Procuram, ao invés disso, alcançar o seu interesse econômico imediato. Em conseqüência, comumente ocorre uma alternação, acima examinada, entre a dedicação ao serviço, quando são novos no emprego, e o desinteresse, quando mais tarde desejam receber indenização, para tentarem abandonar a condição de operário.

\section{O operário qualificado e sua motivação no trabalho}

Um dos modos pelos quais o operário de origem rural pode conseguir um ajustamento mais durável na indústria é pela ascensão dentro da fábrica. Quais as oportunidades que existem para isso, é o que se passará agora a examinar.

Reportando-se ao quadro do pessoal da fábrica em 1957, segundo o local de origem e o grau de qualificação do operário (ver pg. 26), nota-se que no nível imediatamente superior ao de operário não qualificado e semiqualificado, num total de 50 empregados, apenas 19, ou seja, 38 por cento, são brasileiros.
Os empregados deste nível podem ser divididos em dois grupos: em ambos a proporção de estrangeiros é aproximadamente a mesma. Há, em primeiro lugar, operários qualificados, oficiais-ferramenteiros, oficiaisajustadores etc. - grande parte dos quais trabalha nas seções de ferramentaria e de manutenção - e contramestres; em segundo lugar, há os controladores, que preenchem funções auxiliares do processo de produção, tais como a de preparo das máquinas, controle da qualidade do produto e dos aparelhos de precisão. Enquanto os primeiros, ao serem admitidos na firma, já são operários especializados, tendo uma experiência mais ou menos longa na profissão, os do segundo grupo são muitas vezes treinados na própria Companhia.

Tanto para uns como para outros é pré-requisito indispensável um mínimo de escolaridade. O controlador de máquina precisa ser alfabetizado e ter alguma familiaridade com números, que lhe permita ler nos desenhos as dimensões das peças a serem fabricadas e ajustar convenientemente a máquina. Os outros controladores - o de relógio e o de qualidade necessitam uma base escolar maior, pois precisam usar e ler instrumentos de medida de precisão (micrômetro, calibre etc.). Com alguns anos de escola, porém, qualquer operador de máquina, que tenha o nível mental e as aptidões requeridas; pode vir a aprender esses serviços na própria firma em um período de tempo relativamente curto. Por outro lado, o operário qualificado em qualquer dos ofícios da indústria mecânica precisa, além de uma base escolar geral, de uma especialização no ofício que leva anos para ser adquirida, especialização para a qual é necessário em geral mudar várias vezes de emprego a fim de aprender os diversos aspectos do ofício.

Origem sócio-econômica dos controladores e dos operários qualificados

Examinando-se a origem sócio-econômica desses operários que ocupam uma posição imediatamente superior à de operador de máquina, nota-se, como era de esperar após as considerações tecidas, que essa origem varia conforme o empregado tenha um ofício ou desempenhe simplesmente uma das funções auxiliares do processo de produção enumeradas acima. Com grande freqüência os operários qualificados brasileiros são filhos ou netos de estrangeiros, principalmente de italianos; entre os controladores é menor a proporção de ascendência estrangeira. Entre os operários oficiais, sempre referindo-se aos brasileiros, dificilmente encontra-se um que tenha 
trabalhado na lavoura ou cujo pai tenha tido tal ocupação. Já no grupo de controla dores vários são encontrados que começaram a sua vida de trabalho no campo. É maior também entre os oficiais do que entre os controla dores, o número de pessoas que já fazem parte de uma segunda geração industrial, uma vez que seus pais já foram operários.

Apesar dessas diferenças entre controladores e operários qualificados, eles, como grupo total, se distinguem claramente dos operadores das linhas de produção. Enquanto estes últimos vieram da agricultura ou, quando muito, de pequenas vilas quase rurais, onde seus pais ou parentes eram agricultores, e não têm ascendência estrangeira, os primeiros, além de estar, na maioria dos casos, afastados do mundo rural e da vida agrícola pelo menos há duas gerações, são muitas vezes descendentes de estrangeiros e, não raro, seus pais já trabalharam na indústria.

Disto conclui-se que a mobilidade de operários recém-vindos da zona rural para o nível imediatamente superior ao mais baixo da fábrica é rara. Em funções fora das linhas de produção, encontra-se às vezes um ou outro indivíduo que veio da agricultura, que na fábrica aprendeu os rudimentos de um dos ofícios mais fáceis e que são considerados pela administração da Companhia como tendo posição equivalente à de meios-oficiais. É extremamente difícil encontrar na fábrica, porém, alguém que, tendo vivido no campo, esteja hoje trabalhando em ofício completamente qualificado. A maior oportunidade para o operário de origem rural melhorar a sua posição na fábrica é passar de operador da linha de produção para controlador. Diz um operador que está na firma quase desde o seu início:

Tem alguns que eram operários e passaram para controladores". (...) O N. A. por exemplo. Ele é casado: diz que padeceu um pouco na vida e agora fez uma forcinha. Eu não fiz isso e ainda estou na máquina. Ele começou como faxineiro. É de Tambaú, amigo íntimo meu.

Conta N. A. que ficou como faxineiro um ano e meio e que depois o passaram para uma das máquinas da linha.

Passei, pelo interesse meu. Prestava muita atenção no meu serviço. O sr. V. (chefe de linha) perguntou - eu estava parado olhando (o funcionamento de uma máquina) - "por que está olhando ?" Eu disse que queria aprender. "Amanhã você vai pegar (na máquina)", ele disse... O A. era o contramestre. Eu acertava a máquina ${ }^{48}$ e, quando (a peça) saía boa, chamava ele. "Está certo, pode tocar o serviço", dizia... Aprendi a acertar a máquina prestando atenção como o contramestre desmontava e depois como montava outra vez... Depois de um ano e pouco, o V. me tirou da máquina para me pôr como controlador. Ele explicava o serviço nas horinhas que tinha; o resto aprendi sozinho.

Acrescenta noutro momento: "Acho que tive bastante oportunidade na Companhia".

Assim como N. A., vários outros ex-lavradores, que na Companhia começaram trabalhando nas máquinas da linha e demonstraram ter jeito e interesse, a par dos rudimentos de educação necessários, foram promovidos a controlador. A demonstração de interesse por parte do operário, que faz com que o seu chefe "preste atenção nele" e o promova, decorre frequentemente de ter conservado os padrões tradicionais referentes à conduta no trabalho. Assevera N. A.: - "O meu serviço foi sempre igual. Sempre cuidei da minha obrigação. No interior e na fábrica também”.

Percebe-se pelos comentários dos operários, sejam não qualificados ou semiqualificados, que a passagem para controlador, assim como para meio-oficial, é considerada como "subir na fábrica". Diz um dos vigias da Companhia sobre N. A.: "Ele tem uma coisa, não foge do trabalho; foi bem aqui na Companhia, porque é muito delicado, honesto..."

Tanto a promoção para meio-oficial como para controlador representa muito pouco como mobilidade. Comparados com os operadores das linhas de produção, ganham em geral um pouco mais, têm maior prestigio aos olhos dos seus companheiros e gozam de mais regalias (liberdade de movimento, justificação de atrasos etc.). Estas diferenças, entretanto, são pequenas. A melhoria que a passagem para essas posições representa não acarreta um ajustamento que signifique real estabilidade na condição de operário; mormente porque, quando o empregado é obrigado a mudar de emprego, as habilidades adquiridas não lhes são de grande

48 Nem todos os operadores aprendem a acertar a sua máquina; isto é serviço dos controladores. 
utilidade na obtenção, em outra firma, de lugar de nível equivalente ao que antes tinha.

A divisão de status, que nas oficinas da Companhia é nítida, e significa clara distância social, separa operadores de máquina e controladores, de um lado, e operários oficiais e contramestres, do outro. Esta diferença de status é indicada não só pelos melhores salários e tratamento diferente que esses últimos recebem da administração, como também pela relativa ausência de contato entre os membros dos dois grupos, pela atitude de superioridade dos oficiais e pelo desejo dos operários não qualificados e semiqualificados de adquirir rudimentos de um ofício.

\section{Ajustamento do operário qualificado a indústria}

A ascensão do trabalhador rural para a posição de operário qualificado é coisa, como já foi dito, que leva pelo menos uma e, via de regra, duas ou três gerações para completar-se. $\mathrm{O}$ fato de exigir a aquisição de uma profissão qualificada quase sempre um aprendizado desde a meninice, bem como o fato de o filho de lavrador frequentemente migrar para São Paulo quando rapaz (porque é então que são maiores as suas possibilidades de emprego na cidade), tornam muito difícil aquela mudança de posição em uma geração.

Examinando-se a origem e a vida profissional dos operários oficiais de nacionalidade brasileira, pode-se observar quão pequena é a tradição industrial. . São muito poucos os que vieram de família operária; muitos deles também quase não têm treinamento formal e sim uma formação prática de natureza precária. Vejam-se os seguintes exemplos. O ajustador C. A. é natural da Capital de São Paulo e filho de italianos.

Seu pai era açougueiro e seu avô paterno, camponês na Itália. C. A. tem o primário completo, mas o único curso profissional que freqüentou foi o de desenho, por dois anos, no Liceu de Artes e Ofícios. Desde a idade de 14 anos, quando se empregou como aprendiz numa oficina de motocicletas, tem trabalhado em mecânica. Entretanto, com 28 anos, largou o seu ofício por quatro anos para, como sócio de seu cunhado, tocar para diante um empório. Aborreci-me, declara, e voltei para a minha profissão.” Tem hoje 56 anos de idade.
M. C., ferramenteiro, é de Tatuí (São Paulo). Não tem ascendência estrangeira. Seu pai era telegrafista em estrada de ferro e o seu avô, dono de uma loja de ferragens. Fora o primário, não tem outro curso. "Comecei a minha vida de operário com 19 anos."

Antes, trabalhara em balcão e como encarregado de turma em um laboratório. Dos 19 anos até hoje, que tem 33, só tem trabalhado em mecânica. Declara: - "Não me considero um fracassado; embora tenha começado tarde, com 19 anos, nunca tive uma decepção".

Os operários, para adquirirem uma profissão, precisam começar a trabalhar cedo no ofício. Além disso, eles salientam também a necessidade de mudarem com freqüência de emprego, pois, como um torneiro-mecânico declarou, "quem não se formou, precisa mudar muitas vezes de serviço, para aprender os diversos setores da mecânica".

Às vezes, mesmo operários qualificados revelam não estarem satisfeitos com o emprego industrial. (M. C. por exemplo, confessa que não tem vocação para a sua profissão. "Eu gostaria de deixar algum dia de ser operário; mas ter a minha profissão como uma garantia, se algum dia precisar novamente exercê-la. Deixar de ser operário, para ter um meio de vida assim como vendedor de praça, viajante vendedor ... um ambiente mais elevado...") Entretanto, são eles em geral que revelam um maior ajustamento à indústria, como mostra a relativa constância em sua profissão. É a escassez de mão-de-obra qualificada nas indústrias paulistas o principal fator que acarreta certa estabilidade no status desses indivíduos, cuja formação indica, como se viu, a falta de tradição industrial.

Inquirido sobre os problemas da indústria que considerava de capital importância, um dos diretores da Companhia declarou sem hesitação que o maior é a paucidade de trabalhadores qualificados em relação à demanda. $\mathrm{O}$ chefe da ferramentaria, por seu lado, disse que nenhum operário da sua seção, incluindo-se mesmo os estrangeiros, é qualificado como o é um operário oficial na Europa. Esta situação do mercado de trabalho coloca os operários qualificados numa posição muito acima da dos outros.

Da facilidade de os operários oficiais arranjarem novo emprego decorre que, para eles, ao contrário do que acontece com os outros, os aumentos espontâneos concedidos pela firma, durante o intervalo que entremeia dois dissídios coletivos, ultrapassam o aumento concedido por 
acordo entre os sindicatos patronal e de trabalhadores. Deste modo, como os aumentos espontâneos são concedidos com a condição expressa de serem compensados no aumento que for estabelecido por acordo intersindical, tais acordos não têm nenhum efeito sobre os salários dos operários qualificados. Diz um oficial da ferramentaria:

Cada quatro ou cinco meses aparece um aumento, ou melhor, exigimos um aumento. Se não dá, se vai embora, a gente diz. Como não tem outro (para pôr no lugar), dão.

E sobre o aumento que estava para vir com o novo dissídio:

Não adianta. Este ano tive nove cruzeiros de aumento. Todo o ano vem aumento do sindicato, quatro, quatro cruzeiros e cinqüenta centavos, nesta base. Este ano já estou na frente do aumento do sindicato uns quatro cruzeiros. Não adianta nada para mim.

Deste modo, o operário oficial quase não precisa preocupar-se com aumento de salário. Além disso, por causa ainda da escassez do trabalho especializado, ele tem oportunidade de aumentar o que percebe por mês, trabalhando regularmente horas extraordinárias.

S. G., por exemplo, que é ferramenteiro e é considerado pelo seu chefe tão bom como os da Europa, trabalha habitualmente até às 21 ou 22 horas e quase sempre também aos sábados, quando não funciona a maioria das seções. Em média, faz de 90 a 100 horas extras por mês.

A condição econômica relativamente boa do operário qualificado decorrente da execução de horas extraordinárias de trabalho e da política de salários deliberada mente adotada pela Companhia, a fim de segurá-lo, serve para explicar o fato de permanecer ele em média muito mais tempo no emprego do que os outros ${ }^{49}$. São também determinantes dessa permanência a maior condescendência dos chefes em questões de disciplina, o respeito e prestígio de que gozam e a satisfação que têm na execução do serviço.

Um membro da administração superior da fábrica declarou: "Deve-se ser muito mais tolerante com os mais qualificados do que com os outros.

${ }^{49}$ A freqüente mudança de emprego deste tipo de trabalhador, mencionada atrás, ocorre enquanto ele ainda está aprendendo a sua profissão.
Aqueles coitados lá embaixo, eles têm de tolerar muito mais disciplina, pois não precisamos tanto deles; podem ser substituídos".

Depois de atingir o status de operário qualificado, a sua permanência no mesmo também decorre, como já foi dito, do valor atribuído na indústria à posse de um ofício e do prazer que sente nesse tipo de trabalho. Esta afirmação é confirmada pela simples observação deste operário no trabalho, bem como pelo tom e interesse com que fala dos ofícios da mecânica.

B. L. conta que, depois de dois anos como plainador na Companhia, pediu para ser mudado para ajustador mecânico, pois achou que aquele "não era um ofício muito bom, não dava para ganhar muito e era muito fácil". Mais tarde, como "eu era muito caprichoso me puseram como calibrista... Eu gostava de olhar o serviço do outro calibrista. Coisa bonita, serviço delicado".

Assim o operário oficial, além de ser menos frequentemente dispensado pela Companhia, também menos vezes abandona voluntariamente o emprego, para procurar ocupação mais conforme com a sua índole, como é o caso do trabalho por conta própria para o operário não qualificado e semiqualificado.

Relação dos operários qualificados com os outros: falta de identificação com o sindicato

O operário oficial, em suma, comparado com os outros operários, tem um status bem mais alto, tanto do ponto de vista econômico como social, e alcançou um ajustamento à indústria bem mais estável, o que é indicado não só pelo fato objetivo de um maior grau de permanência como operário, como pelo subjetivo, de aceitação ou mesmo apego à sua ocupação.

A assimilação de valores urbanos por mais de uma geração é um elemento importante para explicar esse ajustamento ao status de operário por pessoa com pouca ou nenhuma tradição industrial. É indispensável, entretanto, para compreender o fenômeno, notar o convívio que tem com os operários qualificados estrangeiros, muito mais familiarizados com os valores profissionais da indústria, quando não são descendentes de longa linha de operários e artesãos. 
A origem social diversa do operário qualificado e do que não o é, assim como a diferença fundamental no valor social atribuído à ocupação de um e de outro, criam a grande distância social que existe entre eles. A propósito, por exemplo, da greve programada para julho de 1956, um ajustador mecânico declarou que, na ferramentaria, onde concentram os operários oficiais, todos eram contra, "pois não tinham do que se queixar da firma". Acrescentou que nas linhas havia um tal D., que era "o agitador daquele pessoalzinho lá": "Os do norte, sabe como é, loucos por uma briguinha!" Esta maneira de os trabalhadores oficiais se referirem aos operários "da produção" é característica. Todos lá tendem a ser englobados como "nortistas", "paus-de-arara" ou "baianos", embora apenas um quarto do total provenha do Nordeste e da Bahia (ver pg. 26). Usam esses termos indiscriminadamente mesmo em contato direto com os operadores de máquina. Um operário especializado, que, por força de seu serviço, está sempre nas proximidades das linhas, de passagem, ao ver o entrevistador conversando com F. A., um dos operadores, perguntou em tom de brincadeira: "O senhor vai entrevistar este baiano aí?" Enquanto ele se afastava, F. A., que é de Minas Gerais, murmurou em tom ressabiado: "Só que não sou baiano..."

Os aumentos obtidos através da ação sindical, como já foi constatado, quase nada significam para os operários oficiais; por isso acham, é claro, que não precisam do sindicato, a não ser para resolver problemas individuais. Os movimentos de reivindicação coletiva (salário mínimo, aumento salarial, congelamento de preços) são considerados por eles como do interesse apenas "dos da produção".

Em suma, o sindicato é identificado com o operariado não qualificado e semiqualificado. Os problemas com que essa organização se ocupa não levam em conta os interesses do operário especializado. Disto resulta o fato de os operários oficiais que, pelo seu ajustamento à indústria, era de se esperar estivessem mais envolvidos na luta sindical e que, devido à falta de mão-de-obra especializada, teriam talvez as maiores probabilidades de êxito, são justamente aqueles que se mantêm mais passivos e se colocam à margem do sindicato.

É interessante comparar a identificação com a atividade sindical existente em São Paulo, verificada na base desta pesquisa, com a que ocorre em países industrializados há mais tempo, como é o caso dos Estados Unidos e o da Inglaterra.

O sindicato, pela sua organização legal, é em São Paulo um único para todos os trabalhadores de determinado ramo industrial (no caso que interessa a este estudo, para todos os trabalhadores das indústrias metalúrgicas, mecânicas e de material elétrico de São Paulo). Esta estrutura legal, por si só, é sem dúvida de grande importância sob muitos aspectos. Basta lembrar que os contratos estabelecidos entre os sindicatos de trabalhadores e os patronais têm efeitos normativos para os contratos de trabalho de todos os empregados dos ramos industriais em questão. Por outro lado, não deixa também de ter importância saber quais os empregados que se identificam com a ação sindical. Devido aos fatores apontados, essa identificação quase cessa quando se passa do operário semiqualificado para o oficial, embora se deva acrescentar que mesmo entre os primeiros ela é bem fraca.

Estes fatos parecem refletir o estágio do desenvolvimento social e econômico. Poder-se-ia mesmo sugerir, como hipótese, que quanto mais antiga a história industrial e sindical de uma região, tanto maior a amplitude dos diferentes níveis de trabalhadores que se identificam com uma única organização sindical de que participam. Na Inglaterra, onde o sindicalismo é arraigado, frequentemente o mesmo sindicato inclui empregados desde a base até um nível bem alto da estrutura industrial, sendo membros da mesma organização, trabalhadores braçais, operários especializados, mestres, empregados de escritório e, às vezes, até técnicos. Nos Estados Unidos, por sua vez, onde, por uma série de razões, apesar de ter a indústria sido implantada bem cedo, atrasou-se o movimento sindical são em geral membros de um mesmo sindicato (nas industrial unions) trabalhadores abaixo do primeiro nível de supervisores; os mestres e os empregados de escritório, quando são sindicalizados, o que nem sempre acontece, fazem parte de organizações próprias.

No Brasil, não se fugiu à regra. Não obstante exista, na sua forma legal, um só sindicato para todos os empregados da empresa, a realidade sociológica parece ser outra. Até mesmo operários qualificados já não se identificam com a organização sindical, embora muitas vezes nominalmente dela façam parte. 


\section{A "barreira" étnica}

Para finalizar, é preciso tocar rapidamente na principal causa de perda de estímulo para os operários qualificados. na Companhia. Trata-se do fato de para eles não existir, no quanto possam ver, possibilidade de melhoria na fábrica. É frequiente a afirmação de que toda a vez que se vaga uma boa posição, um europeu é empregado para ocupá-la. Todos os empregados apontam o fato, que é, aliás, verdadeiro, de na Companhia todos "os chefes" (cargos acima da posição de contramestre) serem estrangeiros, em geral alemães. Enquanto os operadores de máquina dizem isto naturalmente, o operário qualificado às vezes o faz com tom amargo. Um destes, não estando completamente sóbrio, queixou-se longamente e entre outras coisas disse: "Aí na fábrica o que existe é predominância racial. Basta ser estrangeiro para ter cargos superiores!" - e pouco depois ajuntou: "Sou o encarregado (de tal serviço)... até que eles arranjem um alemão!" Outro falou magoado: "Não é para desfazer da raça, mas aqui um alemão, pode ser ignorante, entra ganhando mais!"

Independentemente de terem ou não esses estrangeiros habilidades e conhecimentos que os brasileiros não possuam, a crença na discriminação faz com que os operários qualificados brasileiros mais ambiciosos tenham o seu interesse e motivação no trabalho diminuídos. Este fator, é claro, quando a pessoa está bem ajustada ao status de operário qualificado, pode resultar apenas na sua saída da emprego, não acarretando o abandono da profissão.

\section{Conclusão}

Neste trabalho foram examinados alguns dos aspectos da mobilidade social da qual participam pessoas que são oriundas da lavoura e do comércio de pequenas comunidades do interior do Brasil e que constituem a maior parte dos que executam os serviços não qualificados e semiqualificados nas oficinas de uma fábrica moderna. Esses trabalhadores não se identificam imediata e completamente com a condição de operários industriais. Conservando os valores sociais ligados a atividades econômicas independentes, que trazem do seu ambiente tradicional, repetidas vezes procuram abandonar a indústria para voltar a ocupações agrícolas ou para ingressar no comércio, seja na metrópole paulistana ou numa pequena cidade do interior. Embora frequentemente não realizem essa intenção e continuem como operários, ela se reflete no seu comportamento no trabalho.

Os operários da Companhia, do nível em questão, são recém-vindos de um mundo rural onde o trabalho, quando não totalmente, pelo menos na sua rotina quotidiana, é regulado por uma teia de relações familiais prescritas pela tradição; tradição que não deixa de tocar mesmo até as relações quase puramente econômicas como as com o proprietário da terra e com os comerciantes que lhes compram produtos agrícolas ou lhes fornecem as mercadorias de que carecem. Desligados dessa estrutura social que controlava a sua conduta, eles, na fábrica paulista, tendem a se comportar conforme os seus "interesses pessoais".

Sem quase nenhuma experiência anterior com padrões de cooperação que os unam a pessoas com as quais não têm parentesco, na nova situação em que se encontram, o vago sentimento de constituírem um grupo que se opõe aos patrões não é suficiente para a formulação de objetivos grupais e desenvolvimento de ação coletiva, quer no âmbito de uma seção da fábrica, quer em círculo mais amplo. Não há, portanto, normas sociais, acompanhadas de sanções, que, nascidas no ambiente industrial, guiem e limitem o seu comportamento; este deriva em última análise do que é entendido, no consenso grupal (consenso que, é claro, surgiu na interação que continuamente se processa entre pessoas que têm um acervo de experiências no mundo rural em grande medida semelhante), como sendo "o seu interesse".

Reflete-se este num comportamento que, esquematicamente, pode ser assim descrito: no começo, o operário aplica-se ao serviço "para se fazer" na fábrica, obter melhoria de salário e de posição; com o passar dos anos, ao mesmo tempo que diminui a sua expectativa de receber aumento na Companhia, pois é isto que vê acontecer com os seus companheiros, desinteressa-se pelo trabalho, realizando-o displicentemente, quando não chega mesmo a sabotá-lo, com o fito de ser despedido e receber indenização. Os seus colegas, como grupo, não interferem nessa conduta. Não impedem a sua alta produtividade quando ainda é "novo na casa", nem tampouco expressam a sua desaprovação quando "amarra" o serviço. Tanto num caso como no outro a sua ação é considerada normal, o que se faz nas circunstâncias. O operário, tendo sido despedido ou, por qualquer motivo, tendo saído voluntariamente do emprego, muitas vezes para tentar trabalhar 
por conta própria, quando mais tarde entra em outra fábrica, repete essa seqüência de comportamento.

Vê-se, pois, que o ajustamento destes rurícolas ao meio industrial é muito precário. Conclusão a que se chega quer examinando-se a sua orientação para atividades independentes, fora da indústria, quer olhando-se para a sua conduta no trabalho. Nesta conduta, que reflete aquela orientação, não se percebe o aparecimento de normas grupais que, sendo especificamente operárias, mostrem um ajustamento mais duradouro a este status.

O exame do pequeno grupo de brasileiros que chegou a operário qualificado mostrou que a ascensão de pessoas dó campo até este status é processo que leva gerações para se completar. Por outro lado, esses operários, embora tenham formação muitas vezes precária e raramente descendam de pessoas que trabalharam em fábricas, já revelam um grau apreciável de ajustamento à indústria. Não só permanecem na condição de operário, como estão satisfeitos com a sua profissão e não mostram desejo forte de abandoná-la. A situação vantajosa em que estão no mercado de trabalho, a grande distância que os separa dos outros operários, assim como a falta de tradição industrial, explicam a quase completa ausência, entre eles, de ação coletiva através do sindicato.

\section{Capítulo II}

Informação e organização: estudo de uma empresa industrial ${ }^{1}$

\section{Introdução}

O aparecimento dos estudos de relações humanas no trabalho deve ser compreendido à luz do período atual de industrialização dos países desenvolvidos. Reinhard Bendix, em livro recente ${ }^{2}$, salienta que a origem desses estudos está ligada ao surgimento da grande indústria, com os seus decorrentes problemas de administração do pessoal. Para ele, o estudo e a prática das relações humanas correspondem à transformação da ideologia sobre o trabalho e a autoridade, provocada por aquela mudança estrutural. Referindo-se à antiga ideologia do entrepreneur da fase inicial da industrialização, escreve Bendix: "O homem de negócios nos Estados Unidos tornou-se um herói cujo êxito financeiro era celebrado como uma vitória moral. Todas as pessoas eram instadas a imitá-lo; todo indivíduo deveria entrar em competição com os seus companheiros. Permaneceu esta ideologia indiscutida, enquanto a administração da mão-de-obra não apresentava problemas. Com a expansão dos sindicatos e a burocratização das empresas econômicas foi necessário fortalecer o controle da direção sobre o trabalhador" "3. A complexidade e a dimensão da empresa moderna exigiu que a competição e a agressividade, preconizadas pelo antigo capitão de indústria, cedessem lugar à valorização das relações harmônicas no trabalho e à integração do empregado à empresa. É nessa situação histórica que se situam os estudos clássicos de relações humanas empreendidos por Elton Mayo e seus colaboradores.

\footnotetext{
${ }^{1}$ Este estudo foi realizado em colaboração com May Nunes de Souza. A introdução e a conclusão do capítulo foram escritas pelos dois autores; a parte referente aos "Aspectos da organização e da administração da fábrica", foi escrita por Juarez Rubens Brandão Lopes e a parte sobre "O sistema de comunicações na Fábrica", por May Nunes de Souza.

${ }^{2}$ Work and Authority in Industry: Ideologies of Management in the Course of Industrialization, Nova Iorque: John Wiley \& Sons, Inc., 1956. Ver especialmente a parte sobre "The Contribution of Elton Mayo to Managerial Ideology" (p. 308-319).

${ }^{3}$ Op. cit., p. 440.
} 
Esta compreensão do problema é de grande importância para o Brasil, onde começam a entrar em voga as técnicas de relações humanas na indústria. Mário Wagner Vieira da Cunha caracteriza bem a questão ao apontar que os "esforços feitos neste campo, entre nós, têm sido no sentido de "uma superficial e mecânica transposição do que nos Estados Unidos se entende por relações humanas", sem levar em conta que os estudos e pesquisas lá realizados correspondem "a estádios de desenvolvimento econômico daquele país, estádios esses distintos daquele por que passa a nossa economia" ${ }^{4}$. Torna-se necessário, acrescenta, "o concurso intenso e pronto das pesquisas" em nosso meio ${ }^{5}$.

Neste trabalho, interessa-nos a questão das comunicações internas nas empresas industriais. Aqui, como nos demais setores da administração do pessoal, a influência dos estudos das relações humanas e da sua ideologia, é dominante. Salienta-se a importância do sistema formal de informações para o ajustamento do empregado ao seu serviço e à empresa e preconiza-se a adoção de práticas de comunicações que refletem a experiência dos países desenvolvidos. Estas práticas especificam o que informar e a quem informar; determinam a implantação dos mais variados veículos de comunicações, tais como o manual para empregados, o jornal da empresa, os quadros de avisos, as reuniões de discussão, os cursos de relações humanas para supervisares etc.; pregam "as duas vias" do sistema de comunicações, incluindo não só a transmissão das informações básicas da direção aos empregados como a destes para aquela direção, por meio de reuniões mistas, sistemas de sugestões, sondagens de atitudes etc. ${ }^{6}$.

As observações já feitas sobre a necessidade de compreender-se as relações humanas em correspondência a determinado período de industrialização, são também válidas para as práticas de comunicações internas. É preciso desenvolver práticas relativas a esse campo ajustadas à fase em que se encontra a nossa economia. Em outras palavras, torna-se

4 "Ideologia das Relações Humanas na Indústria", in Problemas Psicológicos da Industrialização, São Paulo: Serviço de Publicações da Federação e Centro das Indústrias do Estado de São Paulo, 1959, p. 91.

${ }^{5}$ Idem, p. 123.

${ }^{6}$ Boa parte dos inconvenientes resultantes do emprego indiscriminado dessas práticas não ocorrem, talvez, devido à mudança do sentido que certamente sofrem ao serem aplicadas, por serem moldadas pela organização da empresa econômica no Brasil. necessário encarar as comunicações internas como parte da organização da empresa, cuja natureza, por sua vez, depende da fase do processo de industrialização em que se encontra.

Informação e organização estão intimamente entrosadas. A compreensão do sistema de comunicações vigente e a implantação de novos métodos para melhorá-lo, dependem bàsicamente do estudo da forma da organização. Pretender estabelecer inovações ou modificar o sistema existente sem procurar apreender os problemas fundamentais da organização, dificilmente levará a resultados satisfatórios, se não for mesmo prejudicial. Compreender a organização e as condições que determinam o atual tipo de administração são os passos iniciais para o estudo das comunicações e para qualquer tentativa de atuação nesse setor.

Esta é a ordem de idéias que orientou a formulação deste trabalho. Como estudo de caso, pretende apenas caracterizar, primeiramente, a natureza da organização e administração de uma empresa industrial e, em segundo lugar, o sistema de comunicações realmente existente na mesma, procurando compreendê-lo em face daquela organização e administração. Dada a natureza do estudo, parece-nos ainda prematuro preconizar normas práticas no campo das comunicações internas, que sejam adaptadas à natureza das empresas industriais brasileiras. $O$ nosso esforço foi essencialmente de compreensão do problema, um passo em direção ao desenvolvimento de unia técnica ajustada à nossa realidade.

Os dados, nos quais este estudo se baseia, foram colhidos por Juarez Rubens Brandão Lopes ${ }^{7}$, de 1956 a: 1958, numa fábrica de produção em série, através de entrevistas com operários, pessoal técnico, membros da alta administração e da Diretoria, assim como pela observação direta do trabalho ${ }^{8}$. Naquela época, a fábrica contava com um quadro de cerca de

${ }^{7}$ Este material já foi analisado sob o ponto de vista do comportamento do operário de origem rural na indústria. Ver Juarez Rubens Brandão Lopes, "O Ajustamento do Trabalhador à Indústria: Mobilidade Social e Motivação", cap. 12 do livro Trabalho e Mobilidade (Bertram Hutchinson e outros), Rio de Janeiro: Centro Brasileiro de Pesquisas Educacionais, 1960, p. 360-440. (Publicado neste livro às p. 16-86)

${ }^{8} \mathrm{O}$ trabalho de campo iniciou-se com entrevistas com os empregados da empresa em suas casas. Após alguns meses, durante os quais foi ganha a confiança dos informantes, passou-se a frequientar as oficinas da fábrica, fazendo-se observações do trabalho e conversando com os operários e supervisores. Foram realizadas, ao todo, mais de cem entrevistas, em geral de 
quinhentos empregados. Posteriormente, as instalações e o quadro do pessoal da empresa foram consideravelmente ampliados. Em 1959, como complemento do material já coletado, foram feitas outras entrevistas por May Nunes de Souza, a fim de constatar quais as principais modificações ocorridas nos últimos anos no sistema de comunicações e na administração da empresa. Foram examinados, então, igualmente, os comunicados formais utilizados pela empresa, isto é, os avisos, as ordens de serviço, as comunicações internas etc.

O material acha-se ordenado da seguinte forma: em primeiro lugar, a análise da organização e administração da fábrica, feita por Juarez Rubens Brandão Lopes; em seguida, escrita por May Nunes de Souza, uma caracterização das informações prestadas pela empresa aos seus empregados, da divulgação informal de informações, do grau de informações que os em pregados possuem e da sua exatidão, da maneira pela qual são afetados pela situação quanto às informações e, ainda, um estudo dos meios de comunicação utilizados na empresa; no final, o sumário e observações gerais, à guisa de conclusão, de autoria de ambos os autores.

\section{Aspectos da organização e da administração da fábrica}

Pretendemos, nesta parte do trabalho, caracterizar determinados aspectos da organização e da administração de uma fábrica da cidade de São Paulo, focalizando, especialmente, o setor de pessoal.

Nesta caracterização, a forma e os efeitos da administração industrial são vistos como decorrentes, em boa medida, da natureza da estrutura da autoridade. Comparou-se, assim, a fim de obter-se uma compreensão sociológica da empresa como estrutura social, a sua organização e administração com o modelo weberiano de burocracia ${ }^{9}$. Nesta, para Max Weber, as tarefas a serem executadas dividem-se pelos "cargos", cada qual com a sua "esfera de competência" claramente delimitada. Os cargos

uma a duas horas, inclusive com quase todos os mestres e contramestres, com vários membros da alta administração e com os principais diretores.

${ }^{9}$ Max Weber, "Bureaucracy, in From Max Weber (compilado por H. Gerth e C. W. Mills), Londres, 1947, p. 196-244. acham-se dispostos numa estrutura hierárquica. Fundamental na burocracia, nesta concepção, é a organização característica da autoridade, com a correspondente distinção entre o cargo e a pessoa. A autoridade é do cargo, não da pessoa do seu ocupante, e é sempre uma autoridade circunscrita às atribuições desse cargo. Tudo é regido em tal organização por um sistema, deliberadamente estabelecido, de normas abstratas, gerais e impessoais, donde o caráter impessoal e a previsibilidade dos seus processos de administração.

Este tipo-ideal da burocracia ${ }^{10}$ serviu-nos de instrumento de estudo. Foi pela comparação com o mesmo, comparação que fica apenas implícita, que nos guiamos na análise, adiante exposta, da organização e administração de uma empresa industrial.

Antes, porém, de passarmos à consideração dos dados empíricos referentes à fábrica, devemos salientar o caráter exploratório de que se reveste este estudo. Tal caráter resulta necessariamente dos próprios dados utilizados. A organização industrial e os processos administrativos reduzem-se, em última instância, a comportamento de pessoas. Ao invés da observação direta desse comportamento, utilizamos, quase exclusivamente, informações obtidas através de entrevistas. Esta limitação, aliás, freqüente nos estudos sociológicos, é especialmente importante em se tratando dos problemas aqui considerados. Crucial para estes é a natureza racional ou não dos processos de organização e de administração que realmente existem na empresa; a presença ou ausência de atribuições bem delimitadas de cargos e de seções; a nitidez da distinção mesma entre cargo e pessoa etc. Tais fenômenos são dificilmente caracterizados quando o material colhido é proveniente de entrevistas e não da observação direta, mormente pelo fato dos informantes, ao relatarem processos de trabalhe ou ocorrências de serviço, tenderem a sistematizá-los e racionalizá-los. Somente a comparação crítica dos dados assim obtidos permite superar, parcialmente, tal deficiência.

\footnotetext{
${ }^{10}$ Sobre os tipos-ideais, ver os ensaios metodológicos de Weber, principalmente o artigo sobre objetividade nas ciências sociais ("Objetivity in Social Science and Social Policy", The Methodology of the Social Sciences, trad. de E. Shils, Glencoe: The Free Press, 1949).
} 
A verificação da ausência quase completa ${ }^{11}$ de pesquisas sociológicas sobre a administração de empresas industriais no Brasil, levou-nos a proceder à análise do material de que dispúnhamos, embora o mesmo não fosse inteiramente satisfatório. Servirá, sem dúvida, para a formulação de hipóteses de trabalho e para o planejamento de outras pesquisas no campo.

\section{A alta administração da fábrica}

As funções de direção da fábrica estão principalmente nas mãos de quatro diretores. A divisão de trabalho entre eles não é bem definida. Cada um tem a sua área de interesse principal: um trata de problemas econômicos e financeiros; outro dedica-se especialmente às relações com os órgãos governamentais, cujas medidas e diretrizes podem afetar decisivamente as atividades da empresa; um terceiro é o responsável pelos problemas da produção é preocupa-se ainda com problemas de pessoal, os quais anteriormente estavam sob a sua supervisão direta; ao quarto estão especialmente afetas as questões legais e de pessoal. Estas atribuições, porém, não são rigorosamente delimitadas, referem-se mais às atividades rotineiras de cada setor e às menos importantes. A divisão de trabalho da Diretoria altera-se quando um ou outro diretor passa a se interessar por outro setor ou por um novo problema (reorganização interna da empresa, por exemplo). O ponto básico, porém, é que, como os próprios diretores gostam de afirmar, as decisões importantes são tomadas em conjunto, "sem necessidade de voto". O trabalho rotineiro da alta administração e as decisões de menor importância são, portanto, individuais; as mudanças de diretrizes, os problemas de maior gravidade são matéria de decisão coletiva. As divergências são resolvidas pela persuasão ou pelo fato de um ou outro lado ceder, mesmo que não esteja convicto. $O$ que não se verifica é a existência de quaisquer processos formais de se chegar a uma decisão. Deve-se salientar que a prática de reuniões coletivas, quanto aos problemas

${ }^{11}$ A principal exceção é a pesquisa de Mário Wagner Vieira da Cunha em um laboratório na cidade de São Paulo (A Burocratização das empresas industriais, São Paulo, 1951). Precisam, também, ser mencionados: Virginia L. Bicudo, Rodolfo Lenhard e Olinda Sampaio, "Contribuição ao Estudo das Condições de Trabalho e da Personalidade de Mestres de Indústria em São Paulo", Sociologia, vol. XI, nº 2 e 3 (1949), p. 223-252 e 381399 e Otávio Ianni, "Dilema da Burocratização no Brasil", Boletim do Centro LatinoAmericano de Pesquisas em Ciências Sociais, Ano III, nº.3 (agosto de 1960), p. 7-14. importantes (cujos os limites, aliás, não são demarcados), resulta numa imprecisão, ainda maior, das atribuições dos vários diretores e, dado o fato de não haver um elemento executivo logo abaixo da direção, vai repercutir sobre toda a estrutura de autoridade da empresa, como veremos a seguir.

Logo abaixo da Diretoria, encontramos, a cargo dos vários setores da administração da empresa, o contador geral, também considerado gerente administrativo, o gerente de vendas e o gerente técnico. Além disso, há assistentes da Diretoria (um ou dois), o chefe de pessoal, assim como auxiliares de alto nível dos gerentes, tendo todos contatos diretos e freqüentes com os diretores. Usaremos a expressão "auxiliares diretos" para designar este grupo, onde as linhas de autoridade e responsabilidade, como descrevemos a seguir, são pouco claras e que, com a Diretoria, constituem a alta administração da fábrica.

Queixam-se esses auxiliares de que não são informados pelos diretores, clara e explicitamente, de qual seja a sua posição em relação aos mesmos e em relação uns aos outros, de quais sejam as suas atribuições, de que muitas vezes não são consultados ou não participam de decisões da Diretoria que afetam a sua área de atividade e, nem ao menos, às vezes, lhes são comunicadas as diretrizes formuladas a respeito de seu trabalho. Ficam por isso inseguros sobre a sua autoridade e esfera de competência e hesitam em tomar iniciativa nas suas atividades. Conta um dos assistentes da Diretoria:

R. e S. (dois auxiliares diretos dos diretores) participaram de uma reunião sobre a maneira de distribuição de um novo produto, mas não deu certo; eles não sabiam qual era a posição de um em relação ao outro (quem seria o responsável pelo setor).

Esse fato, segundo o informante, falseava completamente a argumentação apresentada de lado a lado.

Os diretores acham que a autoridade não deve ser "dada" pelo superior, mas sim "tomada" pelo subordinado, isto é, este deve tomar iniciativa e responsabilizar-se por aquilo que se sente capaz de fazer. Faz parte integrante deste ponto de vista a idéia de que o subordinado que tem iniciativa e "toma autoridade" para a execução de uma certa atividade não fica com esta atribuição especificamente demarcada; exerce-a enquanto consegue resolver os casos que surgem. A qualquer momento, quando 
aparecem "problemas" ou quando as soluções dadas aos mesmos não são satisfatórias, podem surgir e surgem intervenções de membros da Diretoria.

Esta orientação, como é subentendido pelos diretores, é válida para todos os níveis da empresa. Às vezes, vemo-la atuando em relação ao pessoal das oficinas. Um operário, por exemplo, queixou-se a um dos diretores, quando este percorria as linhas de produção, que o serviço que fazia não lhe dava oportunidade de mostrar a sua capacidade e foi então colocado, pelo mesmo, na posição de contramestre, "para ser experimentado". Com a diminuição dos contatos diretos dos membros da Diretoria com o pessoal dos níveis inferiores, aquele padrão de delegação de autoridade, pela Direção, tende a se restringir aos seus auxiliares diretos. Deve-se apontar, para bem compreender-se a relação dos diretores com as pessoas desse grupo, que a prática de decisão conjunta acima descrita e a falta de uma especificação de funções dos diretores têm, como conseqüência, o fato de qualquer um deles poder intervir (e, de fato, interferir mais ou menos frequentemente) nas atividades de qualquer setor da administração, passando por cima dos respectivos encarregados.

Examinando-se as condições em que os diretores trabalharam, nesta e noutras fábricas, compreende-se melhor a formação desse padrão que regula as suas relações com os seus auxiliares diretos. Antes da formação da empresa, há cerca de dez anos, dois dos diretores (aqueles que têm participação mais atuante na administração da fábrica) já haviam trabalhado em outras empresas industriais, no Brasil, porém, de pequenas dimensões. A. própria companhia, durante os primeiros anos, possuía um quadro de pessoal ao redor de duzentos empregados e os problemas que os diretores tinham para resolver não impediam o seu contato direto e quotidiano com quase todas as operações. O hábito de um dos diretores de passar pelas oficinas da fábrica, diariamente, conversar com os operários e tomar contato direto com problemas, muitas vezes sem importância, mostrava a possibilidade da manutenção do ponto de vista e modo de atuação acima expostos. Os auxiliares da Diretoria eram, então, na realidade, prepostos, substitutos dos diretores. Estes podiam, de fato, "dar" e "retirar" autoridade, conforme "verificavam" a capacidade e iniciativa dos subordinados para a solução dos problemas que ocorriam. E, principalmente, as atribuições desses subordinados não precisavam ser completamente definidas e podiam ser alteradas pelo superior, quando este julgava necessário.
Com o crescimento da empresa e conseqüente diminuição dos contatos diretos da Diretoria com o pessoal e com a maior diversidade dos problemas que agora têm de ser, resolvidos, mudou-se a: situação. Embora, no início de suas atividades, fossem os problemas que os diretores tiveram de resolver cruciais para a sobrevivência da firma - mercado, relações com os grandes compradores, impedimento por parte do Governo da importação do produto que a empresa fabrica, continuidade de fornecimento de matéria-prima - pode-se dizer que, somente quando estes foram resolvidos e as atividades da empresa se estabilizaram, aumentou a diversidade de problemas da alta administração a serem solucionados pela Diretoria. A sobrecarga de trabalho dos membros dessa Diretoria aumentou também, pelo fato de terem eles entrado em novos empreendimentos industriais nos últimos anos. Somente em relação aos níveis mais altos da organização aquele padrão tem possibilidades de manter-se. Nos níveis inferiores - o dos mestres, o dos contramestres e o dos operários - o contato contínuo do pessoal é com os seus superiores imediatos, que não estão em posição de adotar a mesma forma de ação, mesmo porque qualquer "iniciativa" de seus subordinados pode significar atos pelos quais eles precisam responder ${ }^{12}$.

Os diretores parecem estar conscientes, pelo menos em parte, desta mudança de situação. Um deles, por exemplo, discorreu sobre a necessidade de ter "um executor que pudesse ter contato pessoal" com os empregados e as operações, mas concluiu que numa fábrica grande isto não resolveria o problema, porque "o fato de ser (o executor) empregado impede que possa tomar responsabilidade pelas decisões... que possa empregar, promover e despedir quem achar justo, quem merecer..." É significativo o modo pelo qual este diretor visualiza, numa grande empresa, "um executor": deve ser alguém que aja como o dono agiria, se tivesse contato pessoal e direto, isto é, alguém que decidisse com inteira responsabilidade, na base do conhecimento de todos os traços particulares do caso individual. O ideal continua a ser a administração com base nas relações pessoais, característica da pequena indústria. Não se menciona a conveniência, ou pelo menos a necessidade, de instituir procedimentos impessoais e sistemáticos de administração, procedimentos que necessariamente ignoram

\footnotetext{
${ }^{12}$ A forma de atuação dos mestres está analisada abaixo.
} 
as particularidades de cada caso, para vê-lo somente em termos de suas características gerais.

Nota-se, também, a consciência pela Diretoria de que a situação tornou-se problemática, nos esforços empreendidos para estabelecimento de uma seção do pessoal, da qual trataremos posteriormente. Antes, porém, vejamos quais as conseqüências da manutenção, pelos diretores, do padrão de comportamento acima descrito referente à delegação da autoridade. Entre os auxiliares diretos da Diretoria é facilmente perceptível a angústia e a insegurança engendradas por não saberem qual a sua posição, autoridade e atribuições. Se, para alguns, tal situação resulta num incentivo ao exercício da iniciativa e num real alargamento de responsabilidade por novas áreas de atividade, para a maioria, provavelmente, o resultado é oposto: produz inibição da ação autônoma e uma freqüiente necessidade de ratificação, pela Diretoria, das decisões tomadas fora da rotina.

Por outro lado, como os diretores não podem mais atuar continuamente em todos os problemas, a sua ação passou a ter, cada vez mais, o caráter de intervenção esporádica. Certos fatores fazem com que as gerências e seções adquiram graus diversos de autonomia, devido a maior ou menor possibilidade que tenham de resistir a interferências de cima. Assim, como primeira aproximação, podemos colocar as várias gerências na seguinte ordem de crescente independência em relação aos diretores: gerência administrativa, gerência de vendas e gerência técnica.

\section{Comenta um membro da alta administração:}

A gerência técnica, teoricamente, está no mesmo nível das outras gerências, mas, realmente, é mais importante, mais "glorificada", porque (os diretores) não podem achar-lhe substituto como para os outros.

O principal fator responsável por esta posição diferente dos vários setores da administração parece ser, como afirma o informante, a maior ou menor facilidade com que o elemento humano pode ser substituído, dependendo de haver ou não, no mercado de trabalho, pessoas com as qualificações necessárias. Secundariamente, devido à própria forma de delegação da autoridade, também atuam outros fatores, tais como a importância relativa dada pela alta administração aos vários setores de atividade, relações pessoais com os diretores e até características de personalidade (maior ou menor agressividade). Como veremos, ao examinarmos a posição da gerência técnica, a relativa autonomia ganha por este setor é o elemento que lhe permite melhor definir e especificar os procedimentos no trabalho.

Deve-se apontar, como conseqüência geral de suma importância, que o padrão de delegação da autoridade descrito possibilita aos cargos e seções que gozam de certa autonomia, devido à dificuldade de substituição do elemento humano ou à posição estratégica que ocupam na estrutura da empresa, alargarem suas atividades à custa de outros setores da administração da fábrica e mesmo alterarem ou inverterem as relações de autoridade com o correr do tempo. Naturalmente, a organização que disto resulta não obedece a um plano racional, nem tampouco os objetivos de cada setor se ajustam necessariamente aos da empresa. Os resultados deste estado de coisas, no tocante ao problema de comunicações, assim como o papel nessa questão da ausência de um sistema formal de informações, foram analisados noutra parte deste trabalho ${ }^{13}$.

Examinemos, agora, separadamente, a posição e o modo de atuação da seção de pessoal, gerência técnica e mestres.

\section{A seção de pessoal}

O estudo do desenvolvimento da seção de pessoal e das suas atribuições servirá para melhor ilustrar o seu papel, bem como o da Diretoria e o dos mestres, nas diversas funções relativas ao pessoal.

No início do funcionamento da fábrica, o diretor que tinha contatos pessoais mais chegados com os empregados era o que acompanhava, de perto, os problemas de produção; estava frequentemente nas oficinas e era quem resolvia as questões de pessoal, tais como aumentos de salário, promoções, punições, dispensa e bonificações anuais. No escritório havia um encarregado para os serviços de rotina referentes ao pessoal e que, nas suas palavras, além dessas funções, "fazia o caixa, o controle diário do movimento, pois a contabilidade fechava diariamente, a correspondência e tudo que a Diretoria precisava... fiz muitos serviços que eram particulares

\footnotetext{
${ }^{13}$ Ver p. 116.
} 
para eles". Era "diretamente subordinado à Diretoria" e somente depois de algum tempo ficou apenas como encarregado da seção de pessoal.

A criação de uma seção de pessoal teve por finalidade dispensar aquele diretor do trato direto com os problemas de pessoal. Cinco anos depois do início das atividades da fábrica, verificou-se a admissão de um elemento, conhecido de um dos diretores, para ficar encarregado de uma seção de pessoal, "independente" da Diretoria. A forma mesma do recrutamento desta pessoa é significativa, pois mostra que os diretores, antes de mais nada, queriam ter um "elemento de confiança". É interessante notar que os operários mencionam, a partir dessa data, a existência de um maior rigor no trato com eles. Antes da entrada do senhor B., como declarou um deles, a "firma era uma mãe". Depois da criação da seção de pessoal, os antagonismos passaram a concentrar-se nos mestres e no chefe de pessoal; diretores são considerados "muito bons" para os empregados e "pessoas cem por cento".

Segundo um dos diretores - e o ponto de vista provavelmente é representativo - o papel da seção de pessoal deve ser o de "vender" os pontos de vista da administração aos operários e contar à Diretoria o que estes pensam. $O$ sentido dado a esta afirmação torna-se claro com o seguinte incidente. Um auxiliar desta seção não gozava de bom conceito por parte dos diretores, porque andava sempre junto com os operários, não impunha respeito e foi despedido porque foi visto bebendo com eles. Nas palavras de um diretor: "Em vez de obter informações, estava sendo usado por eles". Vemos, assim, que o chefe de pessoal é considerado essencialmente como elemento representante da Diretoria, um elemento da sua confiança, que sirva como seu porta-voz e como canalizador de informações "de como pensam os empregados"; um elemento que facilite aos diretores a solução dos diversos problemas de pessoal na medida em que surgem. Este modo de encarar a seção de pessoal não é conducente à sistematização dos procedimentos da administração nesse setor. A seção de pessoal, pode-se dizer, atua simplesmente como uma compensação à diminuição dos contatos diretos dos diretores com os empregados. Com a presença dessa seção, por outro lado, tornou-se possível diminuir, ainda mais, tais contatos, sem contudo eliminá-los de todo.

Um dos diretores narra o caso em que as operárias de uma seção se negavam a trabalhar horas extras: procurou, então, ouvir separadamente cada uma, pois "não seria boa política enfrentá-las em grupo", a fim de chegar a uma solução do problema:

Eu pus a mão numa beehive. Todas disseram a mesma coisa. Disseram que não podiam se atrasar porque tinham marido, filhos etc.; que não eram como mulheres de pessoas ricas, não tinham dinheiro para ter governante.

Ele concordou com elas e deu uma solução ao caso que não exigia o trabalho extraordinário.

Este tipo de comportamento, entretanto, é agora mais raro. Em casos de reclamações, brigas entre operários etc., é a seção de pessoal que toma o papel de contato direto com os empregados, ficando, porém, a solução do caso com a gerência técnica ou com os diretores. Não foi excluída completamente, como dissemos, a intervenção desses últimos. Embora fosse resolvido pela direção que "não pulariam a autoridade" da gerência técnica, do chefe de pessoal e dos mestres, isto continua a ocorrer, às vezes com resultados ilógicos, como os do caso da concessão de empréstimo a um operário cuja dispensa já havia sido decidida. Deve-se salientar que tais contradições ocorrem devido à natureza mesma do sistema de autoridade predominante na empresa.

Houve alguma formalização de certos aspectos da administração de pessoal, notadamente nos procedimentos de admissão e de aplicação de penalidade (advertências, suspensões, despedida), casos que são sempre compreensíveis devido à situação imposta pela legislação trabalhista brasileira. A regulamentação da aplicação de penalidades, por exemplo, visa a manutenção de um dossiê de cada empregado que ajude o ganho de causa, pela empresa, no caso de haver qualquer questão judicial com um deles ${ }^{14}$.

Foram provavelmente, tais fatores, os responsáveis pela mudança do critério adotado pela empresa nas últimas mudanças efetuadas na chefia da

\footnotetext{
${ }^{14}$ Um membro da alta administração, em entrevista, contou que "antes eles não previam o que poderia acontecer. A minha função lã é preventiva e não só para resolver os casos que já se tornaram problemas". A função "preventiva" consiste, justamente, na introdução de certo procedimentos na administração do pessoal que diminuam os riscos decorrentes de questões trabalhistas.
} 
seção de pessoal; ao invés de procurarem um elemento de confiança, deu-se maior importância à experiência anterior dos candidatos nesse tipo de trabalho.

Em suma, vemos que a função da seção de pessoal consiste na execução de serviços de rotina, tais como manutenção de arquivos, com os dossiê dos empregados, o preparo, de folhas de pagamento, o atendimento de reclamações etc. A decisão, porém, quanto a problemas de certa importância, como admissão de empregados (salvo talvez os de nível não qualificado e semiqualificado), dispensas (principalmente quando envolvem o pagamento de indenização), promoções etc., está nas mãos da gerência técnica e da Diretoria e, finalmente, a maior parte das funções .relativas a pessoal, que numa empresa mais formalizada seriam da seção de pessoal, estão sob a responsabilidade dos mestres: é o caso do treinamento, atribuição de trabalho (a menos quando toca na legislação trabalhista) , mudança de pessoal de uma seção para outra, recomendação de aumentos à gerência técnica etc.

O importante é salientar: a) que esta "descentralização" de funções de pessoal não obedece a normas gerais, nem resulta de delegação explícita de funções; e b) que em qualquer momento, por um motivo ou por outro (geralmente quando se tratam de questões que têm direta repercussão financeira), podem vir decisões da Diretoria "passando por cima" da seção de pessoal e dos mestres.

O funcionamento dessas práticas traz, como conseqüência, uma administração de pessoal pouco sistemática, na qual fatores de ordem pessoal (antipatias, simpatias, relações pessoais) são frequentemente introduzidos.

\section{Gerência técnica e mestres}

Vejamos, agora, para finalizar este sumário da natureza da organização e administração da empresa, alguns aspectos da atuação da gerência técnica e mestria nesta indústria.

É a gerência técnica que apresenta o maior grau de independência em relação à Diretoria. Tal autonomia restringe-se, porém, aos problemas técnicos (sistema de organização da produção etc.), Nestas questões, as decisões parecem ser tomadas, em discussões da gerência com os diretores, havendo até casos da Diretoria pretender introduzir alterações nos procedimentos de trabalho, não o conseguindo devido à resistência da gerência técnica ${ }^{15}$. No que diz respeito à solução de problemas não técnicos, mas que afetam a produção (a dispensa com indenização de um operário que está "amarrando" a produção, a concessão de aumento salarial etc.), o grau de autonomia de decisão da gerência técnica é bem menor. Resulta daí que são os procedimentos técnicos de trabalho que apresentam o máximo de sistematização, enquanto que os problemas que, além de afetarem a produção, têm também um aspecto financeiro imediato, apresentam menor uniformidade e a solução a eles dada é frequentemente, de caso para caso, segundo suas peculiaridades.

Esta falta de sistematização, mais perceptível no que diz respeito aos salários e às dispensas de pessoal, deve ser examinada a fim de esclarecer certos aspectos da posição do mestre na fábrica.

Não há uma política salarial definida e as práticas relativas a salários são desconexas. Esta situação explica, pois, as disparidades de salário de empregados que executam o mesmo trabalho.

Quando das elevações periódicas do nível do salário mínimo, aqueles que ganhavam mais do que o antigo nível, porem, menos do que o novo, não são aumentados proporcionalmente. Ficam com o salário mínimo. Resulta daí que operários, por exemplo, com muito maior destreza e com maior tempo de serviço, que já ganhavam salários superiores ao mínimo, voltam a ganhar a mesma quantia que outros menos hábeis e admitidos posteriormente.

Por outro lado, costuma a empresa conceder aumentos na base de recomendações dos mestres, em geral uma vez por ano, em antecipação ao reajustamento salarial resultante de acordo intersindical ${ }^{16}$. O montante deste aumento reflete, em maior ou menor grau, as simpatias e antipatias dos mestres. Estes aumentos periódicos, devido ao alto grau de turnover dos operários não

${ }^{15}$ Informou, por exemplo, um entrevistado que S. era assistente do diretor encarregado da produção, mas que "nunca pôde fazer nada por causa [da gerência técnica]". Outras informações sobre ocorrências especificas atestam o alto grau de autonomia da gerência técnica em questões puramente técnicas.

${ }^{16}$ No caso dos operários qualificados tais aumentos excedem, via de regra, o do acordo, devido à pressão do mercado de trabalho. Para os outros são equivalentes ao aumento obtido pelo acordo intersindical. 
qualificados e semiqualificados, provocam grandes diferenças no salário de empregados de trabalho equivalente, mas desigual tempo de serviço.

É de notar a tentativa da gerência técnica de colocar uma ordem nos salários, estabelecendo há poucos anos uma escala salarial segundo graus crescentes de qualificação, a fim de disciplinar os aumentos. Na realidade, esta escala nada mais fez do que mascarar um pouco a ausência de uma política salarial, pois, a continuação daquelas práticas já mencionadas, significava, naturalmente, a impossibilidade de correspondência por muito tempo entre salário e qualificação.

Encontramos nos procedimentos de demissão de empregados, quer individual, quer coletiva (cortes para a diminuição de mão-de-obra), o mesmo caráter oportunista de soluções que constituem meros ajustamentos aos aspectos legais e sócio-econômicos da situação, ou mesmo às peculiaridades de cada caso, sem, porém, haver a preocupação de formulação de diretrizes a longo prazo, visando objetivos previamente estabelecidos.

As dispensas de empregados, que não significam para a firma pagamento de indenização, estão quase inteiramente nas mãos dos mestres. Por outro lado, não têm estes autonomia quanto à decisão da dispensa de um operário que esteja restringindo a produção. Esta dispensa fica na dependência de uma série de fatores: montante da indenização a ser paga (dependendo também da percentagem que o empregado está disposto a aceitar num "acordo"); grau de desorganização da produção provocada pelo operário; possibilidade ou não de "forçá-lo" a não sabotar a produção etc., devendo, em todos os casos, ser aprovada pela Diretoria ${ }^{17}$. Entretanto, como são os mestres que levam à Diretoria e à gerência técnica os "problemas" criados por esses elementos que estão "amarrando" a produção, o sistema dá margem não só a "perseguições", como também a "protecionismos" (ajudar um operário a ser despedido com indenização).

Depende igualmente dos mestres o preparo das listas dos que devem ser "cortados" nas ocasiões em que se pretende diminuir a folha de pagamento, sendo então fornecidos a eles pela Diretoria ou gerência

17 Ver pormenores sobre o assunto nos capítulos, "O Ajustamento do Trabalhador à Indústria", p. 65-71 e "A Motivação do Trabalho: Observações sobre a Restrição de Produção", p. 124-134. técnica, para serem seguidos, nesse trabalho, critérios muito, vagos (cortar "os elementos pouco eficientes", "os não disciplinados" etc.). A empresa, em tais cortes de pessoas conforme a sua necessidade de numerário ou outras circunstâncias, às vezes, paga integralmente as indenizações, outras não, propondo então "acordo" 18 .

A falta de sistematização das práticas relativas ao salário e à dispensa de empregados reforça, ainda mais, no tocante à posição dos mestres, a forma de autoridade já analisada. Isso se torna mais claro quando consideramos que a existência de diretrizes claramente formuladas pela alta administração possibilitaria o seu implemento pelos mestres, independentemente de seus superiores. Ao contrário, na situação vigente, os casos, tais como o da dispensa com indenização de um operário que esteja sabotando a produção, têm de ser discutidos com a gerência técnica e com os diretores e por eles resolvidos. Enquanto isto, a produção continua a ser prejudicada pelo operário, às vezes, durante semanas.

Os mestres, para a execução de suas obrigações ("dar produção" e evitar que o volume de scrap seja excessivo), têm certa liberdade de ação, pois, como já foi mencionado mais de uma vez, grande número das funções de pessoal está nas suas mãos, embora não estejam reguladas por normas gerais formuladas pela alta administração. Entretanto, a qualquer momento tal "liberdade de ação" é limitada, (a) pela interferência de superiores, bastando para isto que os resultados da atuação dos mestres sejam considerados insatisfatórios pela alta administração; e (b) por não poderem os mestres agir independentemente nos casos que representem ônus financeiro para a empresa, por tocarem na legislação trabalhista. Se, por um lado, precisam "dar produção", por outro, não têm autoridade para resolver problemas cruciais relativos à eficiência técnica de sua ação. Não é de admirar que os mestres, em entrevistas, sejam unânimes em afirmar que o problema primordial que enfrentam é não poderem despedir "por causa da legislação trabalhista", quem esteja restringindo a produção. Não vêem que o problema é a ausência de uma política clara e definida sobre estas e outras

${ }^{18}$ Esta prática parece ser freqüente no meio industrial de São Paulo e é decorrente da morosidade da Justiça do Trabalho. 
questões de pessoal, ausência esta explicada pela própria estrutura de autoridade da empresa ${ }^{19}$.

Vemos que a análise da organização e administração da fábrica, a, que procedemos acima, mostra, em suma, o papel central de um padrão determinado de autoridade. Este padrão reflete-se com diferentes nuanças nos vários níveis da empresa e acha-se estreitamente relacionado com a ausência de procedimentos administrativos claramente definidos e sistematizados. $\mathrm{Na}$ parte seguinte serão examinadas as comunicações internas na empresa, tornando-se claro como o seu caráter depende intrinsecamente da forma de organização e administração prevalecente na empresa.

\section{O sistema de comunicações na fábrica}

Nesta parte do trabalho tratar-se-á, de maneira geral, das informações e comunicações na empresa; dos efeitos de certos aspectos da administração do pessoal e outros serviços, como por exemplo, dispensa, salário, promoção, empréstimos etc., sobre a satisfação ou insatisfação no trabalho e sobre o moral dos empregados, examinando-se sempre as consequiências das informações ou de sua ausência sobre essas questões; da posição da seção de pessoal e dos mestres, assim como de certos fatores gerais relevantes à compreensão dos tópicos sobre comunicações e moral dos empregados na empresa, tais como a situação étnica.

No tratamento dessas questões, ver-se-á sempre a influência do tipo de organização e autoridade existentes na fábrica.

Antes de prosseguirmos a exposição, achamos conveniente precisar aqui o sentido em que serão usados os termos "informação", "comunicação" e "sistema de comunicações". Informação é usado no sentido comum do termo, algo que é transmitido por um ou outro meio de divulgação. Comunicação é, sem dúvida, mais amplo: refere-se a todos os contatos formais e informais, em que se inserem informações, muitas vezes sem o intuito deliberado de informar; sentimentos, atitudes são transmitidos

${ }^{19}$ Outros aspectos problemáticos da posição do mestre, nesta empresa, acham-se apontados na parte seguinte deste trabalho. de maneiras sutis, por gestos, expressões faciais, entonação da voz etc. tanto quanto ou mais do que as palavras podem traduzir. É neste sentido que procuramos descrever o "sistema de comunicações" existente na fábrica e que inclui as informações. É, entretanto, muito mais amplo que as informações formais, como sejam boletins, quadro de avisos, comunicados, publicações etc.

Para facilitar a exposição far-se-á a verificação e análise do que efetivamente se processa a partir do momento em que o empregado estabelece o primeiro contato com a fábrica, para obtenção do emprego, até sua saída. Este procedimento vai permitir o acompanhamento do sistema de comunicações existente e o conhecimento das normas e processos da empresa, inter-relacionados. Vai permitir também mostrar a posição-chave de pessoas, seções e serviços mais diretamente responsáveis pela transmissão de informações formais ou informais, como a seção de pessoal, o mestre, o serviço de assistência social etc.; vai evidenciar ainda o processo de difusão de rumores que emergem paralelamente e em extensão maior ao sistema formal, mostrando como cada indivíduo, na empresa, se transforma num veículo importante de comunicações decorrente da sua própria condição de empregado.

Não há na empresa um sistema formal de recrutamento. A grande maioria dos empregados, principalmente no nível dos operários, não qualificados e semiqualificados, tomou conhecimento da fábrica nos contatos estabelecidos nas relações de parentesco, vizinhança, compadrio ou relações estabelecidas em pensões. A primeira informação que o individuo recebe sobre a empresa é, pois, através de um empregado ou um ex-empregado. Estes, por sua vez, não receberam informações diretas e, assim, transmitem as que obtiveram informalmente, no convívio dos companheiros de trabalho e com maior ou menor carga afetiva, às vezes, fundamentadas em certas noções dispersas, como "fábrica de estrangeiros" ou informações inexatas, como "vai haver uma vaga porque o chefe mandou um companheiro da seção embora", quando, na realidade, houve simplesmente um corte, não havendo necessidade imediata de substituição.

De posse dessas informações incompletas, e o mais das vezes inexatas, o candidato a emprego procura a fábrica. $\mathrm{O}$ primeiro contato que estabelece com a empresa é na portaria. O chefe da portaria faz uma entrevista rápida, na qual a sua preocupação primeira é perguntar se tem 
documentos, o que sabe fazer e aproveita para ver "a formação moral do indivíduo e também ver se é um andorinha" (indivíduo que muda muito de emprego). Se há vaga e o chefe da portaria julga que ele pode servir é, então, encaminhado à seção de pessoal. Naquele primeiro contato nenhuma informação é prestada ao candidato que, por sua vez, também não costuma fazer perguntas, seja por desinteresse, como acontece com a maioria dos empregados não qualificados, ou por já estarem de posse das informações que julgam essenciais.

Quando não há vaga, a resposta aos candidatos é negativa, estabelecendo-se, frequentemente, discussões pela incoerência entre a informação recebida do amigo ou parente e a tabuleta colocada no portão "não há vagas". Nesse contato inicial, são duas as situações possíveis: ou a maioria dos candidatos a emprego já vem com a recomendação para o mestre (o que é mais comum) e o procura diretamente, sendo então aquele primeiro contato com a portaria mais rápido; ou é o candidato a emprego encaminhado à seção de pessoal e esta, após breve exame dos documentos, envia-o ao mestre. Em qualquer das situações, é ele acompanhado por um guarda e, nesse percurso, quase sempre se estabelece "uma prosinha", onde algumas informações são prestadas informalmente ao sabor do acompanhante. $\mathrm{Na}$ seção de pessoal o candidato a emprego é recebido de forma rotineira e nenhuma preocupação existe em deixá-lo à vontade; não lhe é dada atenção especial e a própria localização da seção, na ampla sala onde se acham os serviços de escritório, contribui para criar-lhe uma situação um tanto constrangedora. Não há entrevista orientada; faz-se apenas a verificação dos documentos.

A seguir, é ele encaminhado ao mestre. Como, porém, quase todos os mestres são estrangeiros, há a barreira da língua e o primeiro contato fica apenas restrito a algumas perguntas fundamentais com relação ao trabalho. $\mathrm{O}$ serviço a ser executado é explicado em termos muito gerais e instruções mais pormenorizadas são dadas pelo contramestre. Se o candidato for aprovado pelo mestre, ele volta à seção de pessoal e é feito o contrato de experiência.

O indivíduo começa então a trabalhar sem ter recebido, por parte da empresa, qualquer informação. Nada the foi informado sobre a fábrica, produto, Diretoria, organização, direitos, deveres e nem mesmo recebeu informações pormenorizadas sobre seu salário. Começa sua vida como empregado às escuras, executando trabalho rotineiro, sem perceber como este contribui para o todo. Não é apresentado aos chefes de outros serviços e nem efetua visita de reconhecimento à fábrica para conhecer o conjunto. Não foi instruído de como se utilizar de serviços e benefícios, ou como proceder em caso de faltas, saídas durante o serviço, atendimento médico, acidentes etc.; apenas recebeu informações excessivamente sumárias, na seção de pessoal, sobre transporte e restaurante.

Devido à precariedade de esclarecimentos, é evidente que o período de adaptação fica na dependência do tipo de personalidade de cada empregado: uns só vão "descobrir" a empresa muito lentamente, sofrendo todas as consequiências do sistema de erro e acerto, passando por dissabores e constrangimentos que poderiam ser evitados. Mesmo depois de empregados há algum tempo, ainda não sabem cousas que lhes são permitidas ou proibidas e, embora muitas das proibições (como, por exemplo, não tomar refeições nos vestiários) sejam feitas em benefício dos empregados, isto não lhes é explicado de forma construtiva, mas só quando aplicadas as sanções, pela transgressão, é que tomam consciência do fato, deixando-os predispostos a não acatarem a ordem ou não se conformarem com ela.

O operário não recebe orientação alguma sobre a organização da fábrica e funções de cada seção; assim, não sabe a quem se dirigir para fazer reclamação sobre salário, promoção, dispensa; quando tem que recorrer a alguém dirige-se indiferentemente ao médico, ao mestre, à gerência técnica, ao serviço de assistência social e até mesmo aos diretores. São freqüentes os casos em que o operário se dirige ao mestre e este responde "isto não é comigo, é lá no escritório" (querendo, provavelmente, se referir à seção de pessoal) e, na seção de pessoal, dizem-lhe: "não é aqui, é com seu chefe!" Isto concorre para criar atritos entre as seções (ver análise à p. 116) .

Os veículos de divulgação geralmente empregados (como jornais, publicações, quadro de avisos em moldes mais modernos, manuais para empregados etc.), para a disseminação formal de informações, não são usados na fábrica.

Há somente comunicados datilografa dos, cujo exame revela os pontos apontados na análise anteriormente feita. Por exemplo, o número de comunicados é bastante reduzido e estes são assinados, indiferentemente, por diretores, gerentes ou "A Diretoria", o que bem demonstra a categoria 
difusa e indiferenciada da delegação de autoridade; a fundamentação para a ordem ser atendida é o fato de "vir de cima"; muitos dos comunicados são dirigidos apenas aos chefes para que estes os transmitam verbalmente aos demais abrangidos pela ordem etc.

Pode-se, então, concluir que esse sistema rudimentar de informações formais, não organizado, acarreta duas consequiências imediatas: a maior proliferação de rumores - sistema de "leva-e-traz" - e a conseqüente filiação, do empregado a este ou àquele grupo, dando margem à formação deliberada de "cliques" antagônicos. (Ver análise à pg. 116) As informações passam assim a ser difundidas unicamente pelo sistema do grapewine que, cada vez mais, se alastra em conseqüência da ausência do sistema formal. A empresa não se preocupa, em nenhum setor, em informar os empregados, de qualquer nível, sobre sua política e decisões, o que tem contribuído, efetivamente, para criar situações de ansiedade (insegurança), seja nos empregados mais categorizados, logo abaixo da Direção, como nos níveis intermediários e operários. Alguns aspectos positivos não têm sido aproveitados para melhorar o moral na empresa e problemas delicados de relações tornam-se ainda mais difíceis com as distorções sofridas por parte dos vários "transmissores". Assim, a mudança da fábrica para melhores e mais amplas instalações, fato que poderia ser aproveitado para desenvolver prestígio, não motivou, como era de esperar, uma série de informações para "promover" a empresa e informar os operários, eliminando preocupações aos empregados como, por exemplo, as relativas ao uso de ônibus etc. A entrevista com C. exemplifica a falta de informações aos empregados e mestres sobre a mudança:

... o meu chefe disse que acha que a fábrica vai mudar, mas ele não sabe quando, que só ouviu que já tem planta aprovada; eu não perguntei mais porque não gosto de andar especulando... e de qualquer maneira o benefício deve ser só para eles (donos)... do trabalhador nunca é.

Ainda a importância da fábrica, contribuindo efetivamente para o progresso do ramo industrial a que pertence, abordando aspectos positivos do desenvolvimento industrial do país, não tem sido aproveitada para melhorar o moral na empresa.

Passamos, agora, a examinar o que se processa em relação a alguns aspectos da administração do pessoal, verificando-se, também, a ausência de informações sobre esses aspectos e, paralelamente, a difusão de noções e sentimentos através de uma teia informal de comunicações, assim como o efeito desse estado de cousas sobre os empregados.

Quando a Direção decide, por razões imperiosas, a efetuar um corte de pessoal, nenhuma explicação sobre os motivos que a levaram a tomar essa decisão é dada aos empregados, nos vários níveis. Por outro lado, os boatos sobre o corte se propagam imediatamente, afetando todos os empregados que ficam angustiados, inclusive os mestres, que se sentem desprestigiados por não terem sido avisados, em tempo oportuno, pela Direção, e, não raro, se certificam do fato por um subordinado. Nem a seção do pessoal, nem a Diretoria emite comunicado formal a respeito, explicando, de forma única e objetiva, as razões que levaram a Direção a agir assim; não formula critérios a serem adotados pelos chefes de seção e, por outro lado, os empregados tomam conhecimento da decisão pelo sistema do "passa adiante" e, "quando tomavam uma decisão dez minutos depois a fábrica toda sabia. Temos um elemento lá que, mesmo antes da decisão ser tomada, ele já passa adiante".

O empregado dispensado, ao receber a comunicação de que foi atingido pelo corte, não recebe, por parte da seção de pessoal, nenhuma explicação por que foi cortado. O processo vigente é representado pelo que está relatado na entrevista com J.:

O S. me chamou no escritório e me dispensou. Não avisaram nada antes lá (na oficina); ele só me disse que os diretores resolveram me cortar e para que eu fosse procurar os meus direitos na Justiça.

É interessante notar como a informação prestada pela própria seção de pessoal, dando ênfase aos "diretores", contribui negativamente para as relações empregado-empregador; o fato reflete também o sistema de autoridade da fábrica, já analisado, ficando implícito que o S. age em nome do diretor e não por força de autoridade nitidamente delegada. A entrevista com M. também ilustra outro aspecto negativo:

"Como eu estava indo bem, veio o meu chefe de seção e perguntou se eu queria ficar como "controlador". Fiquei, pois para mim era melhor devido ao salário. De repente, sem mais nem menos, recebi a comunicação da seção de pessoal... ia para a rua. Meu chefe ficou surpreso e subiu na gerência e ficou falando lá... Depois me disse: "eles não dizem porque..." 
O empregado e o chefe de seção ficaram sem saber os motivos da dispensa, ficando evidente, inclusive, como a posição do mestre ficou sensivelmente abalada. $\mathrm{O}$ clima criado por esse sistema vigente está refletido num fato que nos foi relatado por D., um membro da administração:

Outro dia, quando fazia uma visita pela fábrica, vi um operário, dos melhores, branco, nervoso, sensivelmente agitado. Perguntei-lhe então o que estava se passando. "Acho que vou ser posto na rua, porque recebi um aviso para ir à seção de pessoal." Daí a dias, encontrei-o novamente bem sorridente e disse-me: "Aquilo não era nada, mas até subir lá tinha passado uns maus bocados... pois tenho família!

No caso de demissão, seja por dispensa coletiva, individual ou corte, não tem havido preocupação com a repercussão do fato, seja com relação ao empregado atingido ou junto aos demais. Não são feitas entrevistas de saída, não há critérios únicos distribuídos aos mestres e chefes para sua orientação.

Do processo como são efetuados os cortes, como já foi mencionado (pg. 102-103), o mestre recebe comunicação que deve dispensar um certo número de operários, ficando o critério da dispensa a seu cargo, resultando daí as maiores discrepâncias; são dispensados empregados com quatro, cinco anos de casa, porque determinado mestre optou pelo critério da eficiência, enquanto que em outra seção o critério foi o do tempo de serviço, existindo ainda o critério meramente subjetivo, de mandar embora "porque não ia com a cara dele". Há também os casos de empregados que, ao saberem do corte, começam a "amarrar" a produção para serem dispensados e receberem a indenização ou, ainda, os que pedem para o mestre fazê-lo e este, quando há amizade, o faz, porque "lá em cima eles não ficam sabendo".

Todas essas situações relatadas são efetivamente incrementadas pela falta de um sistema que oriente os chefes para uma ação única, a menos subjetiva possível.

A falta de um sistema determinado de fixação de salários, promoções, transferências, treinamento, estabelecido pela seção de pessoal, vem sendo causa das mais numerosas queixas de empregados devido à diversidade de critérios adotados pelos chefes, criando situações de desigualdade entre os operários e dando origem, também, à formação de estereótipos que surgem em consequiência da falta de sistematização e informação sobre essas questões como, por exemplo, "brasileiro aqui não tem vez", em casos em que um empregado estrangeiro vem de fora para exercer uma função para a qual não havia, internamente, ninguém qualificado para exercê-la.

Não há política de treinamento e aperfeiçoamento para criar uma força de trabalho interna que permita o aproveitamento de indivíduos da fábrica em posições mais elevadas.

Da situação analisada na parte anterior, em que os aumentos de salários são concedidos a critério dos mestres, ocorre que uns acham, por exemplo, que deve haver, dentro de determinada classe, quatro escalas, outros, maior número de escalas intermediárias etc. Acontece que o empregado, ao receber seu pagamento, vai imediatamente "conferir" com o de seu companheiro e comparando sua função e seu salário com outros de condições iguais e descobrindo que há diferenças, acabam por achar que os critérios são todos de ordem afetiva. Ainda a falta de maior comunicação entre os mestres ajuda a estabelecer, entre eles, diferenças sensíveis na forma de agir de cada um, refletindo suas discrepâncias nos operários.

A falta de uma diretriz quanto às possibilidades de promoção vertical ou horizontal tem dado origem a numerosas queixas e conseqüente falta de estímulo e insatisfação no trabalho. Como já foi mencionado, o aumento de salário e a melhoria de posição ficam a critério dos chefes. Estes passam a ser, aos olhos dos operários, os únicos responsáveis pela sua situação financeira e geram-se, então, comentários difundidos como: "naquela seção não dão aumentos, o chefe só dá para os queridinhos dele..." .

É interessante salientar aqui que os aumentos concedidos, seja por iniciativa da fábrica ou por reajustamento salarial (salário mínimo e acordos intersindicais), têm contribuído mais para aumentar, via de regra, a insatisfação dos empregados, do que melhorar as relações empregadoempregador e levam a comportamentos como "amarrar" a produção, ou perder tantas peças, vangloriando-se disso entre si. A entrevista com C. ilustra como a situação é sentida pelos operários:

Da outra vez que passaram a lei do salário mínimo houve reajustamento. Veja agora: antes eu estava com $\mathrm{Cr} \$ 14,76$ por hora portanto, Cr\$ 5,16 acima do mínimo; como aumentaram o salário 
mínimo para Cr\$15,42, fiquei, com o mínimo, mas agora, eu "amarro" mesmo...

Tal situação faz com que ocorra um achatamento na escala salarial, pois as antigas proporções não foram mantidas e os operários se sentem prejudicados. O aumento de salário, dado por iniciativa da empresa, mas que exige que o empregado assine um documento que se vier um aumento por lei será então compensado, também tem provocado efeitos os mais negativos possíveis:

Os estrangeiros são duros com aumentos - quando dão um aumento que não seja por lei, quando vem aumento (por lei) eles tiram. Tive um aumento de $\mathrm{Cr} \$ 1,30$ e quando vier (o acordo intersindical) eles vão tirar.

Da mesma forma, outros benefícios e serviços (empréstimos, farmácia etc.) que foram implantados para melhorar as relações com os empregados vêm dando resultado contrário, sendo causa de muitas queixas; no caso dos empréstimos, por exemplo, as reclamações têm como principais causas a morosidade e a falta de regularidade com que são concedidos; há períodos em que a verba acaba, o empregado não recebe o empréstimo solicitado e os critérios adotados para a concessão são complexos envolvendo a atuação de três seções. Não tendo conhecimento formal de tais critérios, o empregado interpreta o prazo mais longo que o de um colega, como sendo favoritismo.

A situação da seção de pessoal, já analisada na parte anterior, merece maiores comentários do ponto de vista das comunicações. O chefe de pessoal sente-se desprestigiado por não receber informações, e como se pode constatar pelo que vimos até agora, assim como pelo exame das instruções para normas de admissão e demissão do pessoal, a seção não goza de prestígio na empresa e se limita a executar os serviços de rotina indispensáveis como: exame de documentos, preparo de folhas de pagamento, fichas de pessoal etc.

Muitas das funções que deveriam estar afetas à seção de pessoal e lhe dariam maior prestígio estão sob a gerência técnica, sob a responsabilidade dos mestres ou diretamente com a Direção. A seção de pessoal não possui um serviço de empregamento com estudos sobre a média de salários pagos na comunidade; não há sistema organizado de seleção, não são feitas entrevistas com a finalidade de servir a objetivos vários, não há instruções e informações aos empregados novos, não tem um sistema de follow-up, não planeja sistemas de promoção, transferência, demissão, não elabora programas de treinamento para qualificar os empregados da fábrica a galgar melhores posições. Até normas sobre faltas, licenças etc., foram elaboradas pelo médico. A posição da seção na estrutura não está bem definida e o seu chefe não é informado sobre decisões da Direção e o reflexo disso no sistema de informações da fábrica é óbvio.

Os mestres, pela posição que ocupam, constituem fonte natural de informações sendo, por isso, interessante verificar-se um pouco melhor como vêm eles desempenhando essa função na empresa. Na sua quase totalidade, são estrangeiros, decorrendo daí a barreira de idioma e de diferença de culturas. Por outro lado, são técnicos que não receberam treinamento de como lidar com os operários; estão sempre sobrecarregados de serviço e com alta carga de responsabilidade. Nessas condições, não têm tempo e nem paciência para informar os operários, seja sobre assuntos de ordem geral, ou mesmo de serviço; não estão advertidos para a importância da informação. Perguntados se costumam informar os operários, respondem: "Não tenho tempo a perder com esse tipo de conversa".

Em relação ao número de subordinados, segundo um membro da Administração:

$\mathrm{O}$ número de mestres deveria ser muito maior, principalmente se estabelecermos um paralelo com o que se passa (nos países em grau de industrialização mais elevado); (nesses países) um mestre tem sob sua responsabilidade vinte operários qualificados, enquanto que aqui ele tem cerca de sessenta não qualificados, tendo-se ainda que levar em consideração que lá, o número de engenheiros é muito maior, enquanto que aqui é mínimo e ele tem que suprir também essa lacuna.

Além disso, na fábrica, eles estão sobrecarregados com questões que deveriam estar afetas à seção de pessoal, como, por exemplo, efetuar pagamento etc.

Essa situação dos mestres, agravada pela angústia que sentem num país de cultura e língua diversas (deixam transparecer nitidamente certo temor dos operários nordestinos), acrescida ainda da insatisfação por não se sentirem "integrados na empresa" e a ausência completa de treinamento em supervisão, faz com que o mestre tenha certo tipo de comportamento que em nada contribui para as boas relações de trabalho. $\mathrm{O}$ operário, muitas 
vezes, por falta de melhor informação técnica, não executa corretamente o trabalho, comete erros; o mestre o repreende gritando. Isso não é tolerado pelos operários brasileiros que traduzem suas queixas nestes termos: "Estrangeiro é bruto, não sabe falar com a gente, aqueles "bichos d'água" pensam que o operário é cachorro".

Outra entrevista:

Seu Z. gritava comigo (quando errava), eu gritava mais com ele e disse para ele, "olha, nem meu pai gritava comigo". Os estrangeiros são teimosos, quando dizem que uma coisa é ferro, pode ser pau, a gente está vendo, mas ele grita que é ferro e acabou-se.

Pressionados pela gerência técnica para realizar a produção prevista, os mestres ficam angustiados e descarregam nos operários, criando, por parte destes, comportamentos agressivos: a frustração leva à agressão. As consequiências que disso decorrem são ilustradas nesta entrevista: um operário nos diz:

Eles gritam: "precisam produzir mais", se a gente faz 1.400 num tipo de peça, noutro dia o chefe queria saber por que também não fez 1.400 , gritando. Aquilo não é escravidão. Aí então eu amarrava... eu sabia um jeito que quebrava a máquina e ninguém sabia consertar. Punha uma escorinha de modo que, se passasse de certa produção, quebrava as facas. Vinha o mestre gritando; aí eu dizia: "Experimenta o senhor".

Ele começava a tocar e quebrava as facas. A máquina ficava quebrada e eu (de braços cruzados) ganhando por hora.

A angústia dos mestres em manter a produção que lhes é exigida é evidente e eles mesmo dizem: "Lá em cima, eles não querem saber de nada, querem é produção". Eles não se sentem apoiados, nem pelos superiores, e nem pelos subalternos e, também, não se reúnem para discutir problemas entre si e ficam completamente isolados.

O próprio fato dos chefes, segundo dizem, serem todos estrangeiros, da mesma nacionalidade (na realidade há de várias nacionalidades e um brasileiro), cria certa área de hostilidade como se pôde constatar por várias entrevistas. A empresa, por sua vez, nunca procurou informar os empregados chamando a atenção para a contribuição efetiva que os técnicos estrangeiros, aqui radicados, vêm dando, pela sua formação e experiência, ao desenvolvimento da técnica e da indústria do país.
Nenhum esforço da empresa foi feito para melhorar essa situação, ao contrário, parece ter havido casos de interferência da Direção que contribuíram para agravá-la, reforçando o preconceito de que "brasileiro aqui não tem vez". O caso relatado por um empregado é característico e ilustra o que foi dito acima:

O F., contramestre, implicou comigo, dizia sempre "baiano é burro, brasileiro é burro..." Uma vez, o M. (o mestre) disse ao F. que não precisava mais ajustar a máquina para mim que eu já sabia fazer isso. O F. disse: "Mas ele é burro!" Parece que o M. tinha projeto de me deixar como uma espécie de chefe. Eu chefe... (disse contente), O F. tornou a dizer: "Mas ele é burro". Aí saiu uma briga feia. O M. entrou no meio e fomos todos para o escritório, eu no meio, o F. e o M. No escritório ficaram falando (em língua estrangeira) com um dos diretores. Aí então eu disse: "Falem brasileiro". Começaram a falar brasileiro; depois o diretor chegou e disse: "Por que xingou ele?", eu disse que ele vinha me enchendo há muito tempo; vai o diretor e me disse que eles iam me mandar embora. Lá, entre um brasileiro e um estrangeiro, mandam o brasileiro embora, nunca o estrangeiro que é da classe deles.

Embora não se possa considerar que os fatos realmente tenham se passado dessa forma (pois, foram relatados em tom de bazófia), servem, sem dúvida, para ilustrar o tipo de relações e atitudes dos operários e a crença dos mesmos na discriminação dos chefes em relação a brasileiros.

Outro caso foi relatado por mais de um entrevistado para explicar como funciona a fábrica:

Tinha um estrangeiro lá, tem mais de 60 anos, ele pegou no braço do brasileiro que ia entrando na privada, puxou e meteu um soco na boca dele; quebrou os dentes, ficou todo ensangüentado. E entrou na privada. O rapaz não reagiu, dizem que é porque ele é crente. Chamou a polícia, vieram dois guardas. $\mathrm{O}$ estrangeiro nem sabe falar direito $\mathrm{o}$ português. Aí chegaram dois gerentes 20 que são os donos, e levaram os guardas lá para cima. Depois os guardas levaram o brasileiro (que saiu da firma). Para ver como são os estrangeiros!

\footnotetext{
${ }^{20}$ É interessante notar que o entrevistado se referiu aos diretores com a denominação de "gerentes" e "donos" mostrando desconhecimento da posição real dos elementos da alta administração da empresa.
} 
A idéia formada da discriminação, das diferenças de tratamento, de oportunidades e de salários está também difundida nos níveis de empregados mais categorizados. A generalização de todos com respeito aos estrangeiros é que ganham mais em funções idênticas. Isto foi constatado inclusive entre os chefes de serviços.

Esse fato poderia ser explicado pela informação objetiva, uma vez que os fatores que condicionam as diferenças de salários são outros, como, por exemplo, no caso dos mestres. Há mestres estrangeiros com salário inferior ao do brasileiro e os critérios adotados, seja na fixação de salários ou promoções, segundo a administração, dependem da capacidade pessoal, importância da seção, antiguidade e dificuldade de encontrar elementos nacionais qualificados, para certas funções, no nosso mercado de trabalho.

As dificuldades causadas pela situação étnica encontrada na empresa, seja ou não verdade o que foi relatado por vários empregados, é, entretanto, bastante significativa e importante em si mesma; as próprias distorções que possam existir são de real interesse para nossos objetivos, pois representam um estado de espírito que vai influenciar diretamente na aceitação e interpretação de informações.

A falta de informações formais da empresa sobre assuntos que interessam diretamente aos empregados (tais como cortes, aumentos etc.) ou informações que são importantes para que as seções possam executar o seu serviço, têm conseqüências gerais na empresa e precisam ser melhor analisadas. Tal situação tem como resultado inevitável uma espécie de formalização da teia informal de comunicações. Os empregados, ao terem conhecimento que estão sendo tomadas decisões que os afetam diretamente, procuram quem possa informá-los das mesmas. As seções da empresa, por seu lado, também estabelecem canais informais de obtenção de informações.

A própria estrutura da empresa faz com que existam pontos-chave (pessoas ou seções) que estimulam o desenvolvimento dessas teias semiformalizadas de obtenção e propagação de boatos, isto é, existem oportunidades estruturais de manipulação deliberada, por seções ou por pessoas, das teias informais de comunicações. Na fábrica encontramos várias dessas teias, com objetivos próprios e em diversos estágios de força e desenvolvimento. O importante é salientar que esta manipulação calculada das informações é realizada para os fins particulares de seções e pessoas (para o alargamento indevido das suas atribuições e o seu fortalecimento à custa das de outras seções e cargos), além de trazer, como resultante, a luta (e o uso das informações como arma nesta luta) entre os "cliques" que se formam. É inútil acrescentar que, nessa situação, nada adiantaria à Direção procurar destruir uma ou outra dessas "redes"; elas decorrem, antes de mais nada, da falta de informações cuja "posse" é considerada importante pelos empregados e seções, que acabam criando modos de as obterem a qualquer custo.

O sistema formal de informações utilizado se resume unicamente em alguns comunicados datilografados que, analisados, apresentam certas características que bem definem a falta de preocupação da empresa com relação às informações.

O exame dos comunicados formais, escritos, da empresa, do período de 1956 a 1959, revelou os seguintes pontos:

1. O número de comunicados examinados nesse período não é grande, pois, segundo nos foi informado, não havia a preocupação de guardar cópias.

2. A apresentação dos comunicados é completamente inatrativa: cópias em mimeógrafo, má datilografia, má disposição, falta de título específico e redigidas em linguagem inadequada para a maioria dos empregados.

3. Muitos são encaminhados apenas aos chefes para "tomarem conhecimento", embora sejam do interesse de todos, ficando aos chefes a responsabilidade de transmitir verbalmente, aos subordinados, o conteúdo, o que não ocorre na maioria das vezes, ou é transmitido sem muita fidelidade.

4. Os comunicados são assinados, indiferentemente, por qualquer dos diretores, pelos gerentes e, raramente, por um outro chefe. Exemplificando: comunicados sobre feriados, sobre assuntos relacionados com o transporte, relativos a pagamentos de salário, horário de trabalho, justificação de faltas, autorização de saídas durante o expediente, pagamento e trabalho em horas extras etc., são assinados ora por uns, ora por outros, não importando quem seja responsável pelo assunto contido no comunicado. Há sempre duas assinaturas em cada um, podendo ser dois diretores, um diretor e um gerente e, excepcionalmente, dois gerentes. Nenhuma vez, entretanto, foi encontrado um comunicado assinado pelo chefe de pessoal, como era de esperar. 
5. Nenhum comunicado traz, abaixo da assinatura, a referência ao cargo de quem assinou e também não há, como é usual, o nome de quem assinou, datilografado, para reconhecimento fácil e imediato. Nota-se, ainda, que os comunicados enviados não são assinados em cada cópia; são "despersonalizados". Há também comunicados sem nenhuma assinatura, tendo como referência "A Diretoria".

6. Quanto ao conteúdo, é freqüente encontrarmos um comunicado sob o mesmo título geral, "Aviso Geral", com a comunicação de duas ou mais matérias completamente diversas; às vezes, sob o título principal de uma delas, aparece, como parágrafo ou subtítulo, matéria diversa que, pela sua importância, deveria ser comunicada separadamente.

7. Informações de importância fundamental, não atingem seus objetivos, como, por exemplo, o aviso da instalação, finalidades e forma de utilização do "Ambulatório Médico". Muito extenso, em linguagem formalizada e inexpressiva, tem mais as características de documento destinado a ficar esquecido na gaveta, parecendo ter sido elaborado mais para cumprir algum dispositivo legal do que para levar uma mensagem a todos os interessados. Este comunicado, além de não conter nenhuma frase que saliente o interesse da empresa pela saúde e bem-estar dos empregados, contém excesso de itens que poderiam estar separados para melhor e maior assimilação do texto principal. A ineficiência desse documento como veículo de informação é facilmente comprovada quando verificamos que a quase totalidade dos empregados, ainda hoje, desconhece as finalidades e regulamento do serviço médico.

8. Não foi encontrado nenhum comunicado com a finalidade de informar os empregados sobre a fábrica, produto, pessoal, acontecimentos especiais, como aquisição de novas máquinas, construção de novo prédio, mudança da fábrica, implantação de novos serviços e comodidades, como refeitório, assistência social etc.; também não foram encontrados comunicados de interesse mais direto e primordial dos empregados, como instituição de prêmios, abonos, cortes, admissão, mudanças de política de salários etc.

9. Os comunicados não são utilizados como veículos para "vender" a empresa ao empregado; ao contrário, pela forma com que vêm sendo elaborados, parecem estar contribuindo justamente para o inverso; são conduzidos de forma negativa em vez de positiva: assim, o comunicado sobre instituição da "revista" ("apalpamento de vestes" referido; sem necessidade, logo no primeiro parágrafo do comunicado); informações sobre justificação de faltas (as penalidades vêm à frente das instruções de como justificá-las etc.). Outros avisos são incompletos, havendo omissão de parte fundamental, o que, provavelmente, acarreta maior confusão e discussão do assunto. O caso do revezamento semanal de determinada linha de produção, sem explicação do motivo, ficando este a cargo do mestre, exemplifica o que foi dito.

10. Há ainda comunicados que, pela natureza da matéria, poderiam ser utilizados de forma positiva pela empresa; entretanto, isso não ocorre, causando a impressão, às vezes, que o que está sendo comunicado foi feito em cumprimento a uma determinação legal; neste caso está o comunicado sobre as eleições e posse de membros da CIPA, ambulatório médico, uso de óculos, em certas seções, fechamento no carnaval etc.

11. Não há quadros de avisos atraentes, colocados em lugares de fácil visibilidade, comunicados da direção por meio de auto-falantes etc.

\section{Conclusão}

1. A compreensão da organização da fábrica e, nesta, a da estrutura de autoridade é de importância capital para o estudo de seu sistema de comunicações. Fundamentalmente, dois fatos relativos à alta administração condicionam a estrutura de autoridade da empresa. Primeiro, a forma de atuação da Diretoria, caracterizada pela falta de divisão clara de atribuições entre os seus membros; pelo fato das questões de maior importância serem decididas sempre em conjunto; pela ausência de um executivo centralizado; e, essencialmente, pela forma usual de delegação de autoridade, baseada na concepção de que autoridade não deve ser dada, mas sim "tomada" pelo subordinado. Em segundo lugar, a falta de formulação de diretrizes que constituam sistemas de normas gerais e coerentes, principalmente no que se refere ao setor do pessoal (política de salários, promoções, aumentos e dispensas).

2. Os aspectos principais da estrutura de autoridade, resultante dos dois fatos mencionados acima, podem ser assim caracterizados: a) os vários setores da fábrica possuem grau diverso de autonomia, grau este determinado, entre outros fatores, pela importância que a Diretoria lhes 
atribui e, ainda mais, pelo "grau de indispensabilidade" do elemento humano por eles responsáveis (decorrente das condições do mercado de trabalho); b) os setores que têm maior grau de autonomia (o técnico e o de vendas) estão em melhores condições para o estabelecimento de sistemas organizados e gerais de administração; c) nos setores onde o grau de autonomia é menor, o sistema de delegação de autoridade inibe a iniciativa dos elementos que os chefiam, os quais frequentemente sentem a necessidade de ratificação de suas decisões pela Diretoria. É, pois, nestes setores que se verifica maior interferência de membros da Diretoria nas suas atividades de rotina; d) as relações de autoridade e as áreas de competência (atribuições) dos vários setores e seções da empresa são constante e gradualmente alteradas, devido ao padrão de delegação de autoridade; o alargamento ou perda de atribuições e de autoridade ficam na dependência, não somente da capacidade e características de personalidade dos encarregados dos setores, como também das relações pessoais que mantêm com os membros da Diretoria.

3. Há forças e tendências que estão alterando o sistema de autoridade. Na verdade, o crescimento da fábrica e atenção cada vez maior dispensada pelos membros da Diretoria aos problemas de cúpula (problemas financeiros, relações com o Governo, financiamento, relações com os grandes compradores etc.) dificultam a persistência do padrão de delegação de autoridade, segundo o qual cada subordinado "toma autoridade" $\mathrm{e}$ responsabiliza-se por um setor ou área da administração. A atuação da Diretoria apresenta, nesta situação, inconsistências. Os diretores sentem a necessidade de um executivo que centralize a administração da fábrica, mas continuam a definir as funções deste como as de um "dono-substituto" (alguém que resolva cada caso como eles o resolveriam), ao invés de procurarem delegar a autoridade, explícita e claramente e desenvolverem procedimentos impessoais e gerais de administração. Assim sendo, apesar dos diretores se dedicarem cada vez mais aos problemas da alta administração, interferem ainda esporàdicamente em questões administrativas de todos os níveis, muitas das quais de somenos importância.

4. A nova situação veio forçar a criação da seção de pessoal. Com o distanciamento dos membros da Diretoria das operações quotidianas das oficinas e da consideração de "casos" do pessoal, os mestres passaram a constituir, aos olhos dos diretores, uma situação problemática. São freqüientes as queixas que fazem à atuação dos mestres quanto ao modo pelo qual tratam os operários e por não se interessarem pela solução de questões de pessoal: não darem "oportunidades" de promoção, aumento de salário a quem merece etc., não agirem "como donos", recompensando a eficiência e a iniciativa e, finalmente, não usarem a forma de delegação de autoridade que eles, diretores, adotam. A dificuldade de encontrar pessoas que, além das qualificações técnicas, sejam capazes de exercer essa espécie de chefia, torna compreensível a atitude dos diretores ao procurarem, inicialmente, um chefe de pessoal que seja elemento de sua confiança. Assim, o modo pelo qual vêem a seção de pessoal se vai modificando. Devido, principalmente, aos problemas de legislação trabalhista, tem-se procurado preencher este cargo com elementos que possuam experiência na manutenção de registros de empregados e familiarizados com os procedimentos rotineiros da administração de pessoal. Não sentiram ainda, entretanto, a necessidade de desenvolver uma política definida de pessoal, que permita à seção atuar com relativa independência da Diretoria e da gerência técnica.

5. Este último ponto merecer ser desenvolvido. As práticas administrativas relativas a salários e à dispensa de pessoal constam de ajustamentos imediatos ao meio legal e sócio-econômico em que a empresa opera, isto é, aos vários institutos da legislação trabalhista e a outras condições como a morosidade da Justiça do Trabalho, a inflação, a natureza do mercado de trabalho (facilidade do empregado despedido encontrar novo emprego ou voltar para o meio rural de origem, escassez de mão-de-obra qualificada etc. $)^{21}$. A ausência de diretrizes gerais sobre esses assuntos faz com que as decisões sejam tomadas, em cada caso e conforme as circunstâncias do momento, pela Diretoria e gerência técnica. A autoridade dos mestres apresenta, assim, incongruências, principalmente devido ao fato de ficarem eles na dependência daquelas decisões da alta administração. Esta os considera responsáveis pelo nível e qualidade da produção, sem lhes dar; entretanto, a necessária liberdade de ação. Esta liberdade de ação poderia ser determinada pela implantação de políticas (salarial, dispensa etc.), normas gerais que estabeleceriam limites previsíveis para a autoridade do mestre. Tais políticas poderiam ser formuladas tendo em vista uma perspectiva

${ }^{21}$ Ver "O Ajustamento do Trabalhador à Indústria”, p. 16-86. 
mais ampla do que o simples ajustamento imediato ao meio legal e sócioeconômico do momento, perspectiva essa que tivesse como objetivo a alteração desse meio: fixação do operariado, desenvolvimento de "tradição industrial" etc.

6. Quanto ao sistema de informações existente na fábrica estudada, apresenta ele certas características que podem ser agrupadas quanto à. sua possível alteração em:

a) Características ligadas diretamente à estrutura de autoridade e que, portanto, somente poderiam ser alteradas com repercussões em toda a organização. Por exemplo: a ausência de informações relativas à organização, às atribuições definidas de seções e cargos etc.; os comunicados assinados indiferentemente por uma ou outra pessoa; e os comunicados dirigidos somente aos mestres para que estes os transmitam aos operários.

$\mathrm{Na}$ estrutura de autoridade existente dificilmente poder-se-ia encontrar a difusão efetiva de organogramas ou outros tipos de informações que viessem determinar as linhas de autoridade e hierarquia, como são encontradas frequentemente nos manuais de empregados e outros veículos de empresas com alto índice de burocratização.

b) Características diretamente ligadas à forma de administração existente. Por exemplo, as informações ou ausência delas no que se refere a cortes de pessoal, política de salário, promoções, admissões e demissões, indenizações etc.

c) Há ainda características não perceptivelmente ligadas nem ao sistema de autoridade, nem aos processos de administração. Por exemplo, a forma dos comunicados encontrados, a ausência de entrevistas de entrada e de saída etc.

O sistema formal de informações está, pois, diretamente relacionado ao tipo de administração e organização e à estrutura de autoridade exercida na empresa. Assim, informação e organização estão intimamente entrosadas. O estudo do sistema de informações e a implantação de novas técnicas de divulgação para melhorá-lo, depende, estruturalmente, do estudo e da compreensão da organização. Pretender estabelecer novos programas, ampliando ou modificando o sistema existente, sem procurar apreender os problemas fundamentais da organização e relaciona-los não conduziria a nenhum resultado efetivo, mas, possivelmente, a resultados negativos inesperados, desde que as inovações introduzi das só poderiam ser implantadas à medida em que a. organização comportasse essas inovações para não provocar abalos na sua estrutura. $\mathrm{O}$ sistema de informações de uma empresa é, assim, o reflexo do tipo de organização e do tipo de autoridade exercida. 


\section{Capítulo III}

A motivação do trabalho: observações sobre a restrição de produção

\section{A restrição de produção entre operários dos países desenvolvidos}

Pesquisas, estudos e observações esparsas mostram que a restrição de produção entre os operários das indústrias dos Estados Unidos e dos países da Europa Ocidental é um fato, senão geral, pelo menos extremamente comum. O interesse pelo fenômeno vai muito além do ponto de vista puramente prático, pois pode-se concluir da sua compreensão sociológica que é indicativo de aspectos fundamentais da sociedade industrial e do seu desenvolvimento.

Muitas vezes, as observações feitas equivalem apenas a indícios de que a produtividade do operário não atinge a um nível considerado razoável e não permitem caracterizar bem a natureza do fenômeno. Estão neste caso as observações feitas por Taylor sobre a prevalência do que denominou soldiering ${ }^{1}$. A simples constatação do fato, entretanto, não basta. Afirmar que nas fábricas brasileiras, como nas britânicas ou americanas, os operários produzem, às vezes, menos do que poderiam produzir se quisessem, não esclarece bem o problema.

A diminuição de esforços no trabalho pode ter determinantes psicológicos e sociais os mais diversos.

Algumas pesquisas mais cuidadosas têm demonstrado o caráter grupal da restrição de produção observada nos países industriais mais antigos. A restrição resulta da existência de normas e sanções sociais referentes ao trabalho, desenvolvidas pelos grupos de operários ${ }^{2}$.

${ }^{1}$ F. W. Taylor, The Principles of Scientific Management, Nova Iorque: Harper \& Brothers, 1911 (impressão de 1942), p. 13-24.

Não entraremos aqui nas dificuldades de determinar o que seja "razoável" e, portanto, de poder-se afirmar que existe restrição de produção.

${ }^{2} \mathrm{O}$ caráter social da restrição de produção foi, pelo que sabemos, analisado pela primeira
A ocorrência do fenômeno - restrição grupal da produção - foi estudada não só quando os trabalhadores eram pagos por tempo ou recebiam prêmio grupal de produção ${ }^{3}$, mas também quando havia sistemas de prêmios por produção individual. Entre estes últimos, um dos melhores é o de Donald Roy ${ }^{4}$, realizado numa indústria metalúrgica dos Estados Unidos, onde ele permaneceu onze meses como operário. Os serviços eram pagos por produção, havendo em qualquer caso o pagamento de um salário-base, mínimo, de 85 centavos por hora. Roy, através da observação participante, pôde não só documentar a existência de duas formas de restrição de produção, que denominou de goldbricking e quota restriction, como também chegar a estimativas do "custo social" do fenômeno para a empresa (pela diminuição de produtividade) e para os operários (pela diminuição dos salários).

Os serviços eram classificados pelos operários em gravy e stinker, tomando por base se as tarifas pagas por peça permitiam ou não a obtenção de prêmios por produção que "valessem a pena" (salários de um dólar por hora representavam a linha divisória entre serviços considerados "bons" e os "maus" - gravy ou stinker). Neste último caso, quando um serviço poderia resultar em salários por hora que não atingiam um dólar, os operários restringiam seus esforços a um nível muito aquém do correspondente a 85 centavos por hora, por acharem que não valia a pena esforçar-se por prêmios de dez ou quinze centavos por hora.

Esse comportamento era o que se chamava de goldbricking e, às vezes, significava verdadeira luta com a direção da indústria para que fossem aumentadas as tarifas desses serviços. No caso de trabalhos

vez por Max Weber. Ver: "Zur Psychophysic der Industriellen Arbeit", Gesammelte Aufsätze zur Soziologie und Sozialpolitik, Tübingen: J. C. B. Mohr, 1924, p. 61-255. apud Georges Friedmann, Problèmes humains du machinisme industriel, edição revista e aumentada, Paris: Gallimard, 1946, p. 280-281. Ver também, em F. J. Roethlisberger e W. J. Dickson, Management and the Worker, Cambridge, Mass.: Harvard University Press, 1939, p. 409447, o estudo do Bank Wiring Observation Room

${ }^{3}$ É o caso, por exemplo, dos estudos de E. C. Hughes ("The Knitting of Racial Groups in Industry", American Sociological Review, vol. 11, n. ${ }^{\circ}$ 5, p. 512-519) e o do Bank Wiring Observation Room, já referido (Roethlisberger e Dickson, op. cit.).

4 "Quota Restriction and Goldbricking in a Machine Shop". The American Journal of Sociology, vol. 57 (1952), p. 427-442. 
denominados gravy, cuja tarifa era portanto considerada satisfatória, a produtividade não era, ao contrário do que se poderia esperar, a produção máxima que o operário poderia ter, se quisesse. Havia um teto, um limite máximo, para o salário por hora que o trabalhador devia ter, sobre o qual todos os do grupo estavam tacitamente de acordo. Nos serviços considerados "bons", os operários aumentavam o ritmo de trabalho, procurando, porém, não ultrapassar o salário de \$1,30 por hora; essa era a quota restriction.

Havia assim duas formas de restrição de produção: uma para os serviços com tarifas "duras", quando então trabalhavam de modo extremamente lento, e outra para os serviços considerados bons, quando procuravam ganhar prêmios, sem entretanto ultrapassar o limite da produção máxima, considerada aceitável pelo grupo. Como estava então funcionando realmente o sistema de incentivos? Para muitos serviços, o incentivo era negativo, pois os operários trabalhavam de forma deliberadamente lenta; para outros, era apenas parcialmente eficiente, pois representava um estímulo, mas um estímulo que tinha um teto estabelecido pelo grupo.

Estudos, como o de Roy ${ }^{5}$, mostram a necessidade, mesmo para os países industrialmente antigos, de pesquisas que analisem as variantes do fenômeno da restrição da produção e as condições responsáveis por elas. Faz-se mister também a análise de situações industriais onde não aparece a restrição de produção. Os poucos casos negativos, já estudados nos países industrialmente desenvolvidos ${ }^{6}$, encontram a sua explicação em condições econômicas e estruturais da empresa ou do seu ramo industrial, condições estas que resultam, por exemplo, em baixa coesão do grupo operário da fábrica em questão.

As pesquisas sobre restrição de produção realizadas nas fábricas dos Estados Unidos e da Europa Ocidental permitem chegar às seguintes conclusões provisórias:

${ }^{5}$ Ver outros estudos em W. F. Whyte (ed.), Money and Motivation, Nova Iorque: Harper \& Brothers, 1955.

${ }^{6}$ Ver, por exemplo, W. J. Goode e I. Fowler, "Incentive Factors in a Low Morale Plant", American Sociologica,l Review, vol. 14, $\mathrm{n}^{\circ} .5$ (outubro de 1949). p. 618-624 e Tom Lupton, "Social Factors Influencing Industrial Output", Man, vol. 56 (abril de 1956). p. 55-59.
1 A restrição de produção, embora seja um fenômeno coletivo, não ocorre apenas entre operários sindicalizados ${ }^{7}$;

2. Vários autores acham que a origem da restrição de produção está na separação mesma do trabalhador dos meios de produção. Escreve Marriot, depois de examinar os principais estudos sobre o assunto: "Conclui-se que onde a liberdade de ação é diminuída, o indivíduo sente-se

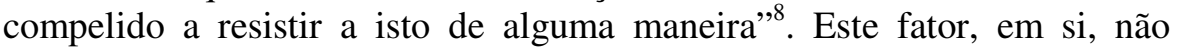
explica, todavia, a restrição grupal da produção. De qualquer forma, nota Marriot que duas foram as maneiras pelas quais a indústria procurou combater aquela tendência: pelo desenvolvimento do trabalho em cadeia e pelo emprego de sistemas de incentivo, de pagamento por produção (esta última maneira, podemos observar, quase sempre acompanhada pela "taylorização" do trabalho);

3. A restrição de produção é fenômeno estreitamente ligado ao movimento de racionalização do trabalho. A "taylorização" e a aplicação de sistemas de incentivo (pagamento proporcional aos esforços despendidos pelo trabalhador) significaram, mormente nas primeiras fases da racionalização 9 , um aumento dos esforços exigidos para a obtenção do mesmo salário anterior e, desta forma, uma contração ainda maior da liberdade de ação do operário. Intensificação do trabalho (speeding-up) e cortes nas tarifas pagas por produção, assim como a experiência coletiva nas depressões periódicas por que passa o sistema econômico, criaram uma "tradição" industrial, no meio operário dos países industrialmente desenvolvidos, que é indispensável à compreensão do fenômeno da restrição grupal da produção.

A existência de uma tradição industrial comum, que transcende os limites de qualquer empresa particular ${ }^{10}$, transparece, por exemplo, na

\footnotetext{
${ }^{7}$ S. B. Mathewson, Restriction of Output among Unorganized Workers, Nova Iorque: The Viking Press, 1931.

${ }^{8}$ R. Marriot, Incentive Payment Systems: a Review of Research and Opinion, Londres: Staples Press Limited, 1957. pg 139.

"Ver exemplos de abusos do "estudo de tempo" no início do século em C. S. Myers, Mind and Work, Londres: University of London, 1920, apud Marriot, op. cit.

${ }^{10}$ A não consideração deste fato é a principal critica que pode ser feita à explicação da restrição de produção dada por Roethlisberger e Dickson (op. cit.).
} 
uniformidade das explicações dadas pelos operários ao fato da participação na restrição de produção, em todas as pesquisas realizadas: afirmam que se não o fizerem "as tarifas serão diminuídas" ou "alguém será despedido" etc. A restrição de produção é, assim, um substituto da greve e "criadora" de emprego $^{11}$; é, de modo geral, um instrumento dos trabalhadores (embora disto não estejam completamente conscientes) para controlarem as próprias condições de trabalho;

4. A restrição de produção é, pois, parte de um processo históricosocial. Inverte-se assim o problema. Sendo geral nos países desenvolvidos a tradição industrial mencionada, o que é preciso explicar são as formas de restrição observadas sob diversas circunstâncias e o fato da mesma não aparecer em certos casos;

5. A tradição industrial responsável pela restrição de produção persiste, apesar mesmo de hoje a maioria dos contratos coletivos de trabalho nos países que estamos considerando, proibirem a diminuição das tarifas de pagamento, a não ser quando mudanças substanciais são introduzidas nos métodos de trabalho. Num sistema econômico no qual mudanças tecnológicas são contínuas e onde, consequentemente, os serviços dos operários estão sendo continuamente modificados, tornam-se necessários novos estudos de tempo a fim de estabelecer novas tarifas. No caso da empresa considerar excessivo o ganho dos operários que trabalham por produção, ela pode introduzir pequenas alterações no trabalho, como pretexto para diminuir as tarifas. Se isto é comum ou não, não é o ponto fundamental, mas sim o fato de serem generalizados no meio operário tais suspeitas e temores. Deve-se lembrar ainda que corte de tarifas é apenas um dos fatores responsáveis pela tradição industrial em questão. Outro fator é o desemprego durante os períodos de depressão econômica (fundamental, por exemplo, para a explicação da restrição de produção nos trabalhos pagos por tempo).

\section{Observações sobre a produção do operário numa fábrica brasileira;} desenvolvimento econômico e restrição de produção

${ }^{11}$ Weber, apud Friedmann, op. cit., p. 280-281.
O estudo do comportamento dos operários referente à produção nos países, no início do processo de industrialização, onde os trabalhadores não pararam pelas experiências coletivas e históricas dos países desenvolvidos e não houve tempo para a formação das tradições industriais de que já tratamos, constitui caso negativo importante para a confirmação da ordem de idéias dos itens acima enumerados. O Brasil, com a sua indústria recente, é campo propício para esta verificação.

Na segunda parte desta comunicação, descreveremos a conduta do operário relativa à produção, numa fábrica da Capital de São Paulo ${ }^{12}$ e, a seguir, teceremos breves comentários sobre os estudos que precisam ser feitos, a fim de se compreenderem melhor as relações entre o desenvolvimento econômico e o fenômeno de controle grupal da produção.

Os operários da fábrica em questão, na época da pesquisa (19561957), eram ao redor de 500 e, na sua maioria, semiqualificados. O trabalho em máquinas semi-automáticas, dispostas em série, podia ser aprendido, via de regra, em poucas semanas. A maioria dos operadores de máquinas provinha de comunidades rurais de São Paulo e dos Estados nordestinos.

Os operários ganhavam, além do salário-hora base, um prêmio, conforme a produção individual, de três ou oito cruzeiros por cem peças, dependendo da máquina. No decorrer da pesquisa, este sistema de prêmios foi abolido, sendo o prêmio médio, ganho pelo operário, incorporado ao seu salário-hora. Nenhum dos dados coletados revela qualquer diferença do comportamento, relativo à produção, decorrente da mudança de sistema de pagamento. A situação descrita é, grosso modo, válida antes e depois da abolição dos prêmios de produção.

Mesmo uma observação superficial destes operários no trabalho mostra grande variação de ritmo. Num dos primeiros dias que passamos na oficina, notamos que havia operadores trabalhando em três ritmos distintos de produção: uma pequena porcentagem trabalhava rapidamente; outros (a maioria) operavam a máquina sem rapidez apreciável, porém sem interrupções; finalmente, uns poucos trabalhavam displicentemente, devagar e, ao que parecia (depois confirmado por dados de entrevista), o faziam deliberadamente. Num outro dia, anotamos no nosso diário, o seguinte:

${ }^{12}$ Estas observações fazem parte do capítulo "O Ajustamento do Trabalhador à Indústria". 
V., enquanto trabalha, acompanha com o pé o com passo de uma música, como que para tornar patente que está "amarrando" a produção. Esteve várias vezes afastado de sua máquina, conversando com outros operários..

A observação do trabalho e as entrevistas com os operários tornaram claro que esse comportamento consistia, de fato, em restrição de produção, reconhecido como tal ("amarração" era o termo), pelo operário e pelos seus companheiros. Ao contrário, porém, do que se verifica nos países industriais mais antigos, não havia restrição grupal de produção na fábrica estudada, ou melhor, não havia qualquer controle grupal do ritmo de trabalho. A própria variação desse ritmo pelos operários, assinalada acima, indicava esse fato.

A procura de sanções sociais referentes à conduta no trabalho, por outro lado, provou infrutífera. Já observamos que havia operários que trabalhavam em ritmo muito mais rápido que os demais. Alguns deles eram pessoas vindas recentemente do meio rural e nas quais se percebia a persistência de valores tradicionais relativos ao trabalho. Os mestres colocavam estes operários no início das linhas de produção, "para forçar a linha toda a trabalhar". O comportamento destes operários provocava ressentimentos de um ou outro colega; entretanto, estas reações eram sempre individuais, não havia sanções do grupo, nem tampouco tentativa alguma de controle do ritmo de trabalho da linha toda pelos operários como grupo.

O operário que "amarrava" a produção o fazia impelido pelos seus interesses individuais; o desejo, muitas vezes, era de ser dispensado e receber indenização depois de vários anos de emprego na fábrica. Os outros operários assistiam à "luta" que se desenrolava entre o operário e o mestre como simples espectadores; não interferiam. Se o mestre, por exemplo, precisasse de alguém que trabalhasse horas extraordinárias na operação que estava sendo "amarrada", para que a linha toda não se atrasa-se, ninguém se recusava a este trabalho extraordinário. Um modo usado pejos mestres para evitar que operárias pudessem "amarrar" a produção da linha era colocá-los fora, em outros serviços. Esta troca de operadores da linha era possível devido ao fato de poder-se treinar em pouco tempo um novo trabalhador na operação da máquina. É indicativo da falta de organização grupal e de solidariedade dos operários o fato de nenhum operário se recusar a substituir, na linha, aquele que estava "amarrando" a produção.
Dissemos acima que o operário "amarra" a produção guiado por seus interesses individuais. É necessário acrescentar que a maneira como define os seus interesses, se, por um lado; revela a influência do valor tradicional do trabalho independente (com a indenização que receber espera entrar em ocupação por conta própria ${ }^{13}$ ), mostra, por outro lado, como a tradição urbano-industrial, formada em São Paulo, define o que o sindicato e a legislação trabalhista significam para obtenção dos seus valores. Tanto o comportamento de alta produção, quando são "novos de casa" e querem "se fazer" na firma, como o de "amarrarem" a produção mais tarde, quando estão há vários anos no emprego, são considerados, nesse ambiente industrial, como "naturais", o que se deve fazer em cada situação.

Vemos, portanto, que a restrição de produção nesta fábrica é fenômeno bem diverso do encontradiço nas indústrias dos países desenvolvidos. Inexiste, aqui, controle grupal do nível de produção; a restrição, quando ocorre, é comportamento individual que demonstra justamente a fraca coesão operária e a ausência de normas e sanções referentes ao trabalho.

Acreditamos que a análise da situação nesta indústria seja válida para outras com as mesmas características, principalmente quanto ao tipo de fabricação, indústrias que, para constituir mão-de-obra semiqualificada, atraem trabalhadores de origem rural, com baixo índice de fixação no meio urbano-industrial.

Apenas com esta pesquisa não podemos chegar a conclusões sobre a organização do operariado no Brasil com referência à produção, inclusive sobre o aparecimento da restrição de produção e suas modalidades. Precisar-se-ia realizar estudos em outros setores industriais, mais antigos e com mão-de-obra mais estável do que o da fábrica estudada; ramos industriais, onde tivesse havido oportunidade de desenvolvimento de "tradições" industriais e que apresentassem diferentes condições econômicas (situação do mercado, por exemplo) e ocupacionais (ocupações tais como a de gráfico, mineiro e estivador são conducentes a rápido desenvolvimento de solidariedade grupal).

${ }^{13}$ Ver o capítulo "O Ajustamento do Trabalhador à Indústria”. 
Por outro lado, indústrias de cidades do interior, com algumas décadas de existência e uma mão-de-obra relativamente estável, constituem uma situação diversa que deve ser analisada. Alguns dados de uma pesquisa realizada em 1958, numa cidade nessas condições, podem ser aqui brevemente mencionados. A fábrica têxtil existente na cidade tinha aproximadamente 1.000 operários e fora fundada há mais de 30 anos. Um primeiro exame dos dados, que ainda se acham em elaboração, mostra a persistência nas relações industriais de padrões tradicionais de trabalho, originados nas propriedades rurais do passado. $\mathrm{Na}$ época da pesquisa, estavam os empregadores empenhados em aumentar a produtividade operária, considerada baixa. Sem estudos sistemáticos, sob a pressão do mercado, os industriais procuravam intensificar o ritmo de trabalho, aumentando o número de teares a cargo de cada tecelã. Estas eram pagas segundo a sua produção e ao passarem de dois para três teares, e depois para quatro, tinham diminuídas as tarifas referentes ao pagamento por metro de pano. As queixas de que, "tocando" quatro teares, ganhavam menos do que com três, eram gerais. É interessante notar que as operárias não passaram para quatro teares todas de uma vez. Nas palavras de uma tecelã:

As tecelãs têm medo de reclamar para o sindicato. Eles (os donos) estão passando (as operárias) para quatro teares aos pouquinhos para não dar força... As que estavam sacrificadas diziam: "Quando vocês passarem (para quatro teares), nós vamos dar um jeito". Nós pensávamos: "Bem que podiam dar um jeito antes da gente passar...

Não havia qualquer indicação de ação conjunta das operárias, nas oficinas, para fazer face a esta situação. O sindicato, entretanto, obteve a procuração de muitas operárias para iniciar uma ação contra a empresa, porque com as novas tarifas por metro de pano não estavam recebendo o salário mínimo da região. Reclamar ao sindicato, neste e noutros casos, significava represálias por parte dos industriais e enfraquecimento das relações tradicionais entre eles e os operários. Por esse motivo muitos desistiam de recorrer ao sindicato.

Os dados apresentados, embora sumariamente, mostram que a homogeneidade do grupo operário, a longa convivência na comunidade e na fábrica, as experiências coletivas comuns no trabalho, aumentam a solidariedade entre seus membros e, por conseguinte, são condições propícias para o desenvolvimento de normas grupais relativas à produção.
No exame superficial do material, ora feito, o principal fator que explica o não aparecimento dessas normas é a persistência das relações tradicionais, que aliás estão sendo lentamente dissolvidas.

Com o desenvolvimento industrial do país, podemos esperar uma estabilização da mão-de-obra fabril, uma difusão de métodos de racionalização do trabalho, inclusive de sistemas de incentivo financeiro (repetindo talvez as formas mais cruas dessa racionalização ocorrida nos países de industrialização mais antiga) e maior aceitação da ação sindical com conseqüente aumento da influência do sindicato. Todos estes são fatores que nos países desenvolvidos levaram ao aparecimento do controle grupal da produção pelos operários.

Não queremos dizer, todavia, que o desenvolvimento industrial implique necessariamente em formação das modalidades mais drásticas de restrição de produção operária. Os países em processo de industrialização não estão recapitulando, é óbvio, o desenvolvimento das indústrias dos Estados Unidos e da Europa Ocidental.

Para finalizar, podemos mencionar algumas condições que distinguem a evolução industrial recente, da industrialização que se processou nos séculos XVIII e XIX, condições que precisam ser consideradas para a compreensão do desenvolvimento das atitudes e motivações do operário relativas à produção. As mais evidentes são: a ação sindical que se desenvolve em clima legal e ideológico distinto daquele do passado; a influência mesma dos institutos legais da indenização e da estabilidade; a maior influência de padrões e valores tradicionais nas relações industriais, devido à rapidez da transformação econômica; e o fato de no Brasil, como noutros países em industrialização, as mudanças tecnológicas mais recentes significarem não uma perda de qualificação pelo operário, mas sim, uma aquisição de qualificação pelo trabalhador rural que se transforma em operário semiqualificado.

Entre nós, poder-se-ia, talvez verificar se essas condições estão realmente atuando no sentido do desenvolvimento de controle grupal da produção, pelos operários, diferente do controle que ocorre nos países industrializados, com estudos nos setores industriais brasileiros mais antigos, que possuem operariado mais estável e apresentem coesão social mais pronunciada. 


\section{Capítulo IV}

\section{Relações industriais em duas comunidades brasileiras}

\section{Introdução}

As relações sociais em toda empresa industrial acham-se, em parte, determinadas pelo tamanho e complexidade da organização, com as implícitas divisão de trabalho, especialização e estrutura hierárquica. Focaliza-se nesse trabalho, entretanto, na sua primeira parte, a forma das relações componentes da estrutura industrial: em que base se estabelecem a divisão de trabalho e a hierarquia, segundos padrões impessoais ou elementos pessoais tradicionalmente definidos ${ }^{1}$.

Era essencialmente desta última forma que, em geral, se organizava (e ainda, muitas vezes, se organiza), no Brasil, a propriedade rural. Existia na sua forma mais pura de organização tradicional quando se baseava no trabalho escravo. A abolição da escravatura e a introdução do vínculo monetário nas relações de trabalho significaram um afastamento do domínio rural do tipo de organização tradicional. Entretanto, embora os trabalhadores sejam hoje empregados do fazendeiro e, por conseguinte, estejam numa relação que sob certo aspecto é impessoal, o caráter pessoal da mesma permanece de grande importância, senão preponderante, no meio rural.

A pressuposição principal desta análise é que na área em estudo - a Zona da Mata do Estado de Minas Gerais - as relações de trabalho haviam chegado a uma situação em que elementos pessoais e impessoais estavam em equilíbrio. Este equilíbrio começou a ser perturbado pelas transformações da própria economia rural (passagem da agricultura para a pecuária), com o

1 Relato preliminar dos resultados de pesquisa realizada pelo autor, em 1958, sob o patrocínio do Centro Brasileiro de Pesquisas Educacionais e da Campanha Nacional de Erradicação do Analfabetismo, do Ministério da Educação e Cultura. Na coleta de dados entrevistas, estatísticas, documentos etc. - o autor foi auxiliado pela Dra. Caroli Martuscelli Bori, da Faculdade de Filosofia, Ciências e Letras Universidade de São Paulo, pelas srtas. Maria Amélia Azevedo, Eva Alterman e Véssia Rodrigues Alves, alunas da citada Faculdade e pelo sr. Ralph Eisenhauer, aluno da Escola de Administração de Empresas de São Paulo, da Fundação Getúlio Vargas. conseqüente aumento da mobilidade horizontal de homem do campo e as tensões produzidas na sua organização familiar. Com a vinda da indústria neste século, acelerou-se a mudança da estrutura patrimonialista tradicional e, neste artigo, pretendemos, justamente, analisar alguns dos aspectos da fase mais recente desse processo. Queremos, em especial, focalizar o papel das organizações de trabalhadores, formadas nos últimos quinze anos, como fator na transformação da natureza tradicional das relações industriais prevalecentes em duas comunidades da região.

Numa das comunidades, Mundo Novo ${ }^{2}$, a primeira fábrica data do início do século. Mais recentemente, a partir de 1936, estabeleceram-se na cidade outras indústrias, havendo hoje quatro fábricas têxteis e uma de papel. Em 1950, essa cidade possuía mais de 2.000 operários numa população total de cerca de 12.000 habitantes. A outra cidade, Sobrado, cuja população somava 10.000 habitantes (1950), possui hoje uma única fábrica de fiação e tecelagem com aproximadamente 900 operários, estabelecida em 1925. Em ambas cidades, o operariado provém, predominantemente, da zona rural circundante, impelido por alteração profunda da economia do campo, qual seja a substituição da agricultura pela pecuária, com a sua escassa mão-de-obra. É freqüente a vinda para a cidade da família rural que, por qualquer razão, é menos capaz de continuar a viver no campo, a fim de empregar nas fábricas, as filhas, menores de idade, que passam, então, a gozar de salários sensivelmente superiores aos dos membros masculinos da família, os quais se empregam, muitas vezes, em ocupações marginais e precárias.

Há claras diferenças entre as relações industriais nas duas comunidades, e mesmo, entre as relações que caracterizam as várias indústrias de Mundo Novo. De um modo geral, em Sobrado essas relações conservam mais completamente seu cunho patrimonialista. Aí os industriais pertencem a uma família tradicional de grandes proprietários de terra, um destes clãs políticos, tão comuns no Brasil. Em Mundo Novo, por outro lado, a família, à qual pertencem os donos da maioria das indústrias, é de origem imigrante pobre, ainda hoje na segunda e terceira gerações, cuja fortuna se baseou, de começo, no comércio e na indústria. Somente de uns vinte anos para cá tornaram-se os chefes políticos locais. Confrontando-os com a família

${ }^{2}$ Os nomes de cidades, fábricas e informantes mencionados neste artigo são fictícios. 
Machado, dominante em Sobrado, vê-se claramente que entre eles, ao contrário daquela, a valorização não é tanto do passado, mas de inovações.

Não obstante essas diferenças, ao tratarmos da natureza das relações industriais nas duas comunidades, o nosso objetivo será evidenciar os elementos comuns às várias situações e somente na análise dos fatores que tendem a modificá-las, entre os quais será destacado o papel do sindicato, prestaremos maior atenção às divergências entre as relações nas diversas fábricas.

\section{As relações industriais}

Empresas que abrangem, na sua estrutura interna, um grande número de pessoas representam um fato relativamente recente na organização social de cidades brasileiras tais como Sobrado e Mundo Novo. O tamanho e as exigências do mercado, em que essas empresas atuam, introduzem, necessariamente, um desusado grau de impessoalidade e racionalidade no comportamento c nas relações sociais dos indivíduos que as compõem. A conduta do operário e as suas relações com os mestres, por exemplo, são claramente moldadas pela divisão de trabalho e pela hierarquia de autoridade estabelecidas com a finalidade de atingir o objetivo de produção para o mercado. Entretanto, além do mínimo de impessoalidade e racionalidade decorrente dessas circunstâncias, há a possibilidade de grande variação. As organizações fabris podem incluir muitas relações pessoais e boa dose de comportamento tradicional.

A importância desses elementos nas fábricas de Sobrado e Mundo Novo torna-se compreensível quando se considera o processo de recrutamento do pessoal e a duração do tempo em que os operários permanecem no emprego. Na fábrica de Sobrado, onde os diretores também são grandes proprietários de terras, a obtenção de emprego na companhia significa, não raro apenas a continuação de uma relação de dependência preexistente. Em ambas comunidades, entretanto, sendo escassas as possibilidades de emprego e ainda rígidos os padrões de uma sociedade tradicional, a maneira comum de obter-se colocação nas fábricas é através das relações pessoais - com diretores, mestres e contramestres - ou apelando para o sentimento de caridade face às especiais dificuldades da própria condição.
Significativo também é o fato de que, quando não conhecem uma dessas pessoas-chave, nem alguém que possa pedir por eles, assim mesmo, ao pedirem emprego, os candidatos o fazem explicando "o seu caso", as dificuldades especialmente grandes que estão enfrentando, como a doença, a família numerosa etc. $\mathrm{O}$ atendimento desses pedidos e, particularmente, a aceitação implícita dessas razões como legítimas e pertinentes, mostram estarem os donos das indústrias no papel tradicional de membros da classe alta e responsáveis, por conseguinte, pelos habitantes da comunidade. Por outro lado, o provimento de emprego nessas situações criam relações de lealdade pessoal especialmente fortes. Na Brasil Têxtil de Mundo Novo, a fábrica mais moderna das duas comunidades, onde a racionalização acha-se mais desenvolvida, criou-se um departamento de pessoal e sua chefia foi entregue a uma pessoa menos ligada à teia de obrigações e expectativas sociais do que os diretores e os mestres. Mesmo nessa empresa, entretanto, a preferência do chefe de pessoal para a seleção de novos operários recai naqueles que "têm um irmão, gente da família trabalhando na fábrica".

Além da introdução, nas indústrias, de relações de parentesco e comunais, a longa permanência no emprego é outro fator de importância decisiva no desenvolvimento do alto grau de pessoalidade nas relações industriais. Nas duas fábricas mais antigas de Mundo Novo, fundadas em 1905 e 1936, cerca de 1/4 e de 1/5 dos empregados, respectivamente, tem mais de quinze anos de serviço na firma.

O longo contato diário, aliado à homogeneidade cultural e à atmosfera tradicional geral das comunidades em que se localizam, são suficientes para dar grande importância às relações pessoais dessas fábricas (importância desusada em indústrias de iguais dimensões), mesmo entre empregados que não se acham ligados por laços de dependência, parentesco ou vizinhança, anteriores ao emprego fabril.

Para a compreensão da administração industrial das em presas de Sobrado e Mundo Novo, assume particular relevância a caracterização da hierarquia de autoridade.

Observa-se desde logo que os mestres gerais, os mestres e os contramestres estão, em geral, entre os empregados mais antigos das 
firmas ${ }^{3}$, refletindo o fato de ser a relação que os liga aos diretores uma relação de lealdade pessoal. São "homens de confiança" dos donos. Esse tipo de relação torna-se evidente quando se nota que muitos desses homens prestam serviços para o industrial, serviços esses que exorbitam de uma simples relação de emprego, estreita e nitidamente delimitada. Um único exemplo servirá para frisar esse ponto: os donos da fábrica de Sobrado são os chefes políticos locais e, em época de eleição, a casa de um dos empregados de categoria da empresa é usada como "curral" para a distribuição de cédulas dos operários.

Casos como este mostram que, ocupando posições de chefia nas indústrias, estes empregados ficam, muitas vezes, ligados a um indivíduo ou a uma família por uma relação pessoal. Este indivíduo ou família "pode contar com ele" para a execução dos mais diversos serviços ou atividades, dentro ou fora da estrutura industrial. $\mathrm{O}$ reverso da lealdade do mestre ou contramestre são as "vantagens" e, de modo geral, a: proteção, em caso de necessidade, que lhe é dada pelo "patrão".

Esta relação entre mestres e industriais parece ser apenas uma modalidade da que tende a surgir no Brasil, particularmente nas zonas rurais e semi-rurais, entre uma pessoa qualquer da classe inferior e alguém da classe dominante, quando há entre eles contatos freqüentes. Neste caso, surgem muitas vezes, gradativamente, expectativas, de lado a lado; um pode contar com o outro. O simples convívio parece criar a obrigação do superior de cuidar, ou favorecer os "seus homens". Se isto, de um lado, possa ser uma tendência universal, na sociedade patriarcal brasileira, rigidamente estratificada como era (e na qual faltava uma classe média), as condições eram especialmente propícias para a intensificação dessa tendência.

No caso que está sendo analisado, as obrigações criadas são especialmente importantes e decorrem da relevância das funções que são desempenhadas pelo mestre. $\mathrm{O}$ patrão na fábrica precisa recorrer, no trato com os subordinados e com os problemas da empresa, a prepostos, e nas

${ }^{3}$ Observa-se uma única exceção. Enquanto os supervisores abaixo de mestre da Brasil Têxtil obedecem à regra formulada no texto, a grande maioria dos mestres nessa fábrica foi admitida nos últimos cinco anos. Essa renovação do quadro de mestria dessa indústria parece estar associada, tanto como a criação do departamento de pessoal, aos esforços de modernização que nela estilo sendo feitos. comunidades estudadas a hierarquia industrial resultante tende, por influência de toda a sociedade, a assumir a forma tradicional de organização, ao invés da racional-legal ${ }^{4}$.

A escolha de contramestres e seus ajudantes pelo mestre faz-se de maneira semelhante à deste último pelo industrial. A seleção ocorre durante o contato diário entre essas pessoas e se dá tanto pela demonstração por parte daqueles elementos de competência no serviço, como pela prova de serem dignos de confiança. A possibilidade do estabelecimento dessa relação de confiança entre o mestre e os seus auxiliares decorre por sua vez da natureza da que ele tem com o industrial. Gozando da confiança deste e de liberdade de ação, o mestre pode, por seu turno, conceder "regalias" a outros.

É também consequiência do caráter pessoal da hierarquia, que as pessoas, num mesmo nível (no de mestre ou contramestre, por exemplo) não têm realmente nem autoridade nem responsabilidades equivalentes. A posição deles, a amplitude de suas atribuições, as "regalias" de que gozam e, em última análise, o poder que têm na empresa, dependem dos laços pessoais que os unem aos seus superiores e, portanto, da "confiança" que esses depositam neles.

Outro aspecto do sistema hierárquico existente é a descentralização administrativa nas atividades que dizem respeito ao pessoal. A admissão de novos operários, a atribuição de serviço, a aprendizagem, a imposição de disciplina (autorização de faltas e atrasos ao trabalho; saídas durante o serviço; e a aplicação de penalidades: suspensões etc.), são funções que estão a cargo dos mestres. Nisto também é válido o que ficou dito atrás: os mestres de uma mesma fábrica, não têm igual autoridade nestas questões. Acresce, ainda, que a autoridade de cada um não é perfeitamente definida, e, sim, resulta do que, costumeiramente, os industriais têm deixado a seu cargo devido a confiança que nele depositam.

É esta a diferença capital entre uma descentralização administrativa racionalmente estabelecida e o tipo tradicional encontrado em quase todas as indústrias de Sobrado e de Mundo Novo. Em ambos os tipos, há delegação de autoridade. Numa estrutura racional, esta delegação acha-se

${ }^{4}$ Ver Weber, Max, The Theory of Social and Economic Organization, Nova Iorque, Oxford University Press, 1947, p. 324-358. 
(a) delimitada por normas administrativas gerais: normas que estabelecem critérios bem definidos à boa administração e (b) sujeita a controles prévios e claros. Na descentralização de estruturas tradicionais, porém, a garantia de que a administração dos prepostos do chefe será segundo interesses deste baseia-se apenas na relação de lealdade existente. Enquanto o chefe tiver confiança no seu preposto, este terá liberdade (subordinada aos limites costumeiros) nas suas decisões.

Qual a natureza dos laços que unem o operário à fábrica? Para grande número das famílias das comunidades estudadas, as fábricas, juntamente com as outras instituições que fazem parte do novo meio industrial (o sindicato, os institutos estatais de previdência social etc.), têm importância capital na organização de suas vidas. Dependem delas, não só para emprego, como também para moradia e para sua segurança face à doença e à morte. Quase todas as empresas industriais das duas comunidades têm "vilas operárias" para os seus empregados, onde estes obtêm casas melhores e de alugueres mais baixos. Além disso, várias empresas também dão certa assistência médica e hospitalar, ou diretamente ou através de facilidades para o seu pagamento. A clara preocupação das fábricas pelo bem-estar do operário e sua família, devemos assinalar, não é fria e calculada; as formas pelas quais se revela não são meios de obter fins preestabelecidos. Essas atividades não são explicitamente justificadas como maneiras de elevar a eficiência operária ou o seu moral, mas, pelo contrário, pelo menos no início, eram expressão espontânea da relação tradicional de patrão e empregado, subordinação de um lado e obrigação de cuidar dos dependentes, do outro. Esta situação é melhor definida em Sobrado, embora valha também para Mundo Novo.

O cunho tradicional das atividades de proporcionar moradia e assistência ao empregado revela-se no modo como são exercidas. Cada um é tratado como uma pessoa total (considerando-se todas as suas peculiaridades pessoais, condições de sua família, suas relações etc.). A tendência é para não haver um atendimento impessoal que leve apenas em conta critérios previamente estabelecidos. Para "dar" uma casa a um ou outro, o único critério que mencionam é o da preferência àquelas famílias que tenham maior número de membros empregados na fábrica. Mesmo este, podemos perceber, não é rigorosamente seguido, havendo toda uma ordem de outras considerações que podem influir, abrindo exceções. Além disso, os modos correntes de obtenção de emprego significam, muitas vezes, relações numerosas e particularmente estreitas do operário com mestres e diretores. Fornecer casa e assistência, portanto, tem sempre por função expressar e reforçar as relações pessoais existentes ou mesmo criálas. Em outras palavras, as relações tradicionais de alasse marcam o modo como a administração das fábricas dá assistência aos operários. Além disso, em casos de crise, moléstia, miséria e morte, todas as pessoas da comunidade recorrem aos industriais para obter auxílio. Estes fatos mostram o papel dos industriais, como componentes da classe alta que são, de protetores dos membros da comunidade.

A relação industrial-operário é muito mais ampla que uma simples relação de emprego. Como toda relação pessoal ela tende a ser total, especialmente numa pequena comunidade. Isto é mais válido para Sobrado do que para Mundo Novo. O empregado não é só um empregado; é uma pessoa que, muitas vezes, os industriais já conheciam desde a infância, bem como a sua família. É também - e nunca deixa de ser visto sob este aspecto - um membro da classe inferior, de quem se esperam freqüentes demonstrações de deferência e respeito. Além disso, como os industriais em Sobrado pertencem à família politicamente dominante, o empregado da fábrica, como era o colono da fazenda, é um "seu eleitor". Esta é uma expectativa tácita. Em dia de eleição, os operários, como os trabalhadores agrícolas, são levados para os "currais" onde recebem as cédulas para daí serem conduzidos às seções eleitorais. A relação do operário com o industrial é total e, portanto, a sua análise, nos aspectos econômico, social e político, é artificial. Isto é ilustrado pelo fato de que ser "da política contrária" é considerado deslealdade e motivo justificável para ser despedido. O caso da "família dos 14" (14 pessoas), por exemplo, que "votaram contra os patrões", andava de boca em boca. Além dos membros que trabalhavam na fábrica serem dispensados, a família foi despejada da casa em que morava, que pertencia à empresa.

Poder-se-ia pensar que o uso das sanções econômicas (dispensa de emprego, perda de moradia) fosse uma expressão de conduta racional. Realmente, nesses casos, não é fácil separar os elementos racionais dos tradicionais. Parece entretanto, não haver dúvida que esse comportamento é também expressão espontânea daquilo que é considerado pelos industriais como quebra de relação tradicional de dependência. Sentindo, ainda, 
profundamente as suas obrigações, em relação ao povo da comunidade, os membros da classe alta reagem de modo severo a toda manifestação de rebeldia. Tanto a assistência que dão como os castigos dispensados fazem parte do mesmo padrão patrimonialista.

Ainda algumas outras expressões desse padrão podem ser mencionadas. Tanto numa como noutra comunidade o operário traz para a fábrica problemas pessoais ou de família, a fim de aconselhar-se ou pedir auxílio aos industriais ou a outras pessoas que ocupam posições altas na estrutura industrial. E finalmente, um último exemplo, especialmente característico, às boas operárias, quando saem do emprego para se casar e pedem "um auxílio", a fábrica dá uma quantia como gratificação. Esse comportamento, de um e de outro lado, constitui claro contraste com o que ocorre comumente nas grandes cidades brasileiras em que o operário procura, através da diminuição de produção, forçar a sua despedida, a fim de receber a indenização prescrita pela legislação trabalhista para a dispensa "sem justa causa". Trata-se nessas circunstâncias de comportamento racionalmente orientado pelos interesses individuais do operário ${ }^{5}$. Em Sobrado e Mundo Novo, por seu lado, é clara a influência de valores e padrões tradicionais, tanto da parte do industrial como do operário. Este acha certo e justo que, quando trabalhou durante bastante tempo para o patrão e foi "bom empregado", aquele lhe "dê" alguma coisa quando sai, uma espécie de recompensa pela sua dedicação. Consoante com esta atitude, quando têm pouco tempo de casa ou por qualquer outro motivo acham que "não merecem”, os operários nada pedem quando precisam sair do emprego.

\section{O papel do sindicato}

A análise das relações industriais, feita como se estivessem num quadro estático, não corresponde à realidade. $\mathrm{Na}$ verdade, há sinais de tensões nas relações nas duas comunidades e clara evidência de que já entraram em um processo de transformação.

Não é difícil identificar os principais fatores de mudança. São eles, em suma, a situação do ramo têxtil, de um lado, e as transformações

\footnotetext{
${ }^{5}$ Ver o capítulo neste livro sobre "O Ajustamento do Trabalhador à Indústria”.
}

político-administrativas por que passa o país, do outro. A indústria de fiação e tecelagem entrou em crise após a Segunda Guerra Mundial, crise que se deve ao obsoletismo do equipamento e à estagnação do mercado. A essas condições, que eram especialmente acentuadas para as fábricas interioranas, juntou-se para essas mesmas fábricas o efeito das decretações de salários mínimos, mormente o de 1954, que diminuíram grandemente as vantagens de que gozavam, face às indústrias mais modernas dos grandes centros, no que tangia ao custo da mão-de-obra. Lado a lado dessa nova situação econômica, as transformações políticas por que passou o país nas últimas décadas significaram a possibilidade de recorrerem, quando preciso, os membros da comunidade local a representantes de grupos políticos desvinculados do dos industriais, a de dar aos trabalhadores vazão, pelo voto secreto, aos seus ressentimentos, e, principalmente, o tornar-se mais eficaz a legislação trabalhista. Foram esses os fatores de mudança. As novas condições de mercado provocaram medidas administrativas das fábricas que estremeceram as relações industriais tradicionais. As mudanças políticas, por sua vez, propiciaram o aparecimento de organizações sindicais independentes.

As reações das indústrias locais à maior concorrência com as fábricas mais modernas e aparelhadas dos grandes centros - com a conseqüente pressão no sentido de modernização de equipamento, racionalização de processos e redução de custos - incluíram: a utilização mais frequiente da dispensa (a fim de substituir pessoal de menor eficiência e salários mais altos por outro, mais produtivo e de remuneração mais baixa), tornada possível inclusive pelo uso de contratos por tempo determinado; a intensificação do ritmo de trabalho pelo estabelecimento, sem base em estudos sistemáticos, de novos níveis de salário-tarefa; o aumento dos alugueres das moradias que fornecem aos operários; a redução de bonificações e da assistência médica e hospitalar; e, pelo menos numa empresa, a Brasil Têxtil de Mundo Novo, a constituição de uma hierarquia de autoridade e de métodos administrativos mais impessoais. Várias dessas medidas criaram atritos dos operários com os mestres e contramestres - seja causados pela maior pressão da direção industrial sobre a mestria para o aumento de produtividade, seja pelas maiores exigências dos subordinados provocadas pelas tarifas baixas de salário, para que os contramestres consertem máquinas - e todas elas significaram enfraquecimento das 
relações de trabalho tradicionalmente definidas. Os ressentimentos gerados por essas circunstâncias tendem a ser canalizados pelo sindicato.

A história das organizações operárias nas duas cidades é elucidativa e precisa ser rapidamente contada. Em Mundo Novo, em novembro de 1944, um ano aproximadamente após a promulgação da Consolidação das Leis do Trabalho, formou-se uma Associação Profissional de Trabalhadores na Indústria de Fiação e Tecelagem, sob a inspiração, aparentemente, dos próprios industriais. Essa organização não teve qualquer atuação durante cerca de três anos, até que, em 1948, alguns operários achando que, na realidade, os diretores da entidade não tinham intenção de fazer nada, resolveram fundar outra associação. Encontrando dificuldades, ingressaram na associação existente e desalojaram a sua diretoria.

O relato da fundação do sindicato de operários de Sobrado mostra interessante paralelo com a do de Mundo Novo ${ }^{6}$. Contam os operários que, desde 1946, mais ou menos, havia na cidade o "sindicato do toucinho", considerado por todos como "dos patrões". Tinha aquele nome porque, com as mensalidades, comprava porcos cuja carne era vendida, com vantagem, somente aos trabalhadores, num açougue perto da fábrica. Essa era a sua única razão de ser. Em 1954 os operários conseguiram autorização do Ministério do Trabalho para formar um sindicato. Os industriais, após verificarem que não conseguiam evitar, através de pressões mais ou menos veladas, a formação da organização operária independente, procuraram assegurar, na eleição sindical, a diretoria, para elementos de sua confiança. Entretanto a sua chapa perdeu. Conta o presidente do sindicato que se não fosse a presença de fiscais do Ministério, com a intimidação dos mestres e contramestres no dia da eleição indo de casa em casa, pedir que votassem na chapa do patrão e comparecendo na hora da eleição, no sindicato, "com lápis e papel na mão" (ostensivamente, como quem ia tomar nota) - a "chapa dos operários" teria perdido.

${ }^{6}$ Não foi possível verificar, tanto em Mundo Novo como em Sobrado, se a criação de "sindicatos" foi política deliberadamente seguida pelos empregadores, para evitar a formação de organizações independentes por parte dos operários. Esta é a crença de muitos trabalhadores nas duas cidades. Devemos apontar, também, que a simples formação de organizações, com elementos de confiança dos industriais, quando se reativa a atividade sindical no país, é significativa e constitui claro paralelo ao que ocorreu na história industrial de muitos outros países.
Este relato dos esforços de operários, imersos numa organização social tradicional, na conquista de uma ação independente, é altamente significativo. O simples fato de procurarem transformar a associação em sindicato, por iniciativa própria, foi considerado pelos patrões como rebeldia, e, embora alguns operários declarassem que o que estavam fazendo não era "ir contra o patrão", cada um dos atos dos principais participantes mostrava a consciência de que estavam possuídos, de participarem de um desafio sem precedentes, em Sobrado. Que ousassem fazê-lo, somente podia ser explicado pelo apoio político de pessoas, de classe alta (através, por exemplo, de um operário de Mundo Novo, cuja ligação com o chefe político da oposição de lá, sem dúvida, era conhecida) e pela existência da legislação trabalhista.

Qual a atuação do sindicato nessas comunidades? Um exame superficial dos tipos de casos tratados pelos sindicatos das duas cidades, como eles são relatados nas atas das assembléias gerais e das reuniões de diretoria, mostram diferenças significativas quanto ao papel do sindicato nas relações industriais em ambas as cidades. No sindicato de Sobrado, as reclamações individuais são em menor número e as duas principais questões em que o sindicato interveio desde o início - o não pagamento do salário mínimo e o aumento do aluguel das casas de propriedade da companhia - afetaram a grande maioria dos empregados e eram considerados, aos olhos dos dirigentes sindicais, clara violação de preceitos legais. Já em Mundo Novo, verifica-se maior número de casos individuais em que a interferência do sindicato é procurada e, em contraste com a situação em Sobrado, algumas das queixas a ele trazidas para atuação junto às empresas - atuação, às vezes, bem sucedida - dizem respeito a condições gerais do trabalho e não especificamente a esfera econômica. Especialmente significativo, no tocante às diferenças de atuação do sindicato nas duas cidades, é que, na primeira, os operários, através da diretoria do seu sindicato, por mais de uma vez, participaram de reivindicações coletivas de salário e, pelo menos duas vezes, em 1956 e em 1958, chegaram a um acordo salarial com a direção das empresas industriais.

A explicação de tais diferenças de atuação das organizações sindicais das duas comunidades jaz no grau de aceitação das mesmas, por parte dos industriais. Enquanto em Sobrado a atitude destes é de franca hostilidade ao 
sindicato, em Mundo Novo, vários são os que, pelo menos publicamente, toleram a organização e, às vezes, entram em entendimentos com ela.

Em Mundo Novo, no início, parece terem sido tensas (como hoje o são em Sobrado) as relações entre a organização dos trabalhadores e a direção das indústrias ${ }^{7}$. Um exame das relações sindicais em Sobrado, na época em que foi realizada a pesquisa, indica a primeira fase de um processo, cujo curso acha-se mais adiantado em Mundo Novo.

Em Sobrado, nas duas ocasiões em que o sindicato propôs questões judiciais em nome de seus associados, contra a fábrica, os industriais iniciaram campanhas, pressionando os empregados a assinarem cartas desligando-se da organização sindical. Aqueles que haviam dado a procuração autorizando o sindicato a agir em seu nome e não pediram o seu desligamento da entidade trabalhista, "perderam os seus direitos na empresa", tais como, por exemplo, o adiantamento para pagamento de médico ou de receitas, e empréstimos.

A não aceitação do sindicato pela fábrica, em Sobrado, como portavoz dos empregados, ressalta nitidamente, quando se comparam dois casos de reivindicações, feitas por grupos de operárias, quanto a mudanças nas condições de trabalho. No primeiro, em que o grupo reivindicava mais tempo para limpeza dos teares, o pedido foi feito nos moldes tradicionais, ao mestre da tecelagem, e a reivindicação foi atendida. No segundo caso, um outro grupo de operárias, após solicitarem várias vezes ao mestre e aos diretores um período de descanso durante a tarde, dirigiram-se ao sindicato e o presidente deste levou a solicitação ao diretor da Companhia, salientando "que as moças haviam prometido trabalhar até mais tarde, para compensar a meia hora de café". O diretor despediu, no mesmo momento, duas das moças e ameaçou as outras com igual medida. O ocorrido ilustra bem que recorrer ao sindicato é visto, pelos diretores da fábrica, como uma deslealdade. É como se colocassem a alternativa: ser leal ao sindicato ou à empresa.

${ }^{7}$ Considerando-se o desemprego nas duas cidades, a dependência que estão os trabalhadores das firmas industriais e a não aceitação do sindicato, a participação mais ativa neste (membros da diretoria, ida freqüente à sede etc.), como é natural, limita-se àqueles trabalhadores que, por lei, gozam de estabilidade na empresa e, por um motivo ou por outro, distanciaram-se da direção das indústrias.
Tendo em vista a posição assumida pela fábrica de Sobrado, entendese o modo de agir do presidente do sindicato. Quando um ou outro operário faz queixa contra a fábrica, o presidente, ao ver que o problema diz respeito a um grupo de operários (de uma seção ou de todos os inquilinos de casas da fábrica, por exemplo), pede que a reclamação seja feita em conjunto. Obtém, assim, procuração dos reclamantes e apresenta a queixa de maneira formal à administração da empresa. Caso não seja atendido, a questão vai a juízo. É compreensível também que, pela escassez das oportunidades de emprego na cidade e devido à atitude do empregado para com o sindicato, não sejam freqüentes tais casos. Desde a fundação da organização dos trabalhadores, em 1954, além de poucas reclamações individuais no início de sua existência, o sindicato recorreu à justiça em dois casos individuais e em dois coletivos (não pagamento de salário mínimo e aumento do aluguel das casas operárias).

Em Mundo Novo, porém, se em algumas fábricas a atitude do empregador não difere muito da dos diretores da fábrica de Sobrado, nas outras é, em geral, de tolerância. Nestas condições vemos o presidente do sindicato tratando, rotineiramente, de muitos problemas individuais enviando ofícios aos diretores das empresas ou procurando-os pessoalmente.

Sentimos a aceitação do sindicato, em Mundo Novo, pelas indústrias como representante dos seus empregados, nos entendimentos havidos várias vezes para obtenção de acordo de aumento salarial. Quão desusado era este fato, do sindicato pedir um aumento coletivo, é verificado através das declarações do presidente sindical em uma assembléia realizada em 1956, quando se cogitou pela primeira vez do assunto. Disse então que estava pronto a solicitar o aumento desejado pelos associados, mas, acrescentou: estes deviam dar "em caso de perseguição aos membros da Diretoria por parte dos empregadores, todo o apoio aos referidos dirigentes". "Não só apoio financeiro, como também pessoal, garantindo a mim, presidente, a defesa de minha família." Não só desta vez, mas em outra, em 1958, as negociações resultaram em pequenos aumentos coletivos, considerados "vitórias do sindicato". 


\section{Conclusão}

De acordo com o que ficou exposto, podemos supor que o papel do sindicato, nas duas comunidades em estudo, representa duas fases da introdução da organização operária numa situação em que as relações de trabalho são, em alta medida, definidas tradicionalmente.

A primeira reação, representada pela indústria de Sobrado e, com menor intensidade, por uma ou outra fábrica de Mundo Novo, é de considerar a procura do sindicato, pelo operário, como a quebra das relações tradicionais, levando o industrial a sentir-se desobrigado do dever de "cuidar" de seus empregados. Em Sobrado, como vimos, os operários que recorrem ao sindicato "perdem os seus direitos na fábrica". Na primeira fase, a administração da empresa procura destruir, abertamente, a organização operária, ou pelo menos, "desincentivar" a sindicalização entre os operários.

Atitudes semelhantes às da fábrica de Sobrado encontramos em outras duas empresas de Mundo Novo. Entretanto, podemos dizer que, em gerai, em Mundo Novo as relações das empresas com o sindicato estão num segundo estágio. Até mesmo os diretores das duas fábricas mencionadas acima participaram de uma reunião com a diretoria do sindicato em abril de 1958, cuja finalidade era decidir o aumento de salários. Os dirigentes das outras fábricas têm contato mais freqüente com o presidente do sindicato, aceitandoo habitualmente, como intermediário nas relações com os empregados.

Vários informantes, ao relatarem a maior preocupação dos empregadores pelos seus operários, até há bem poucos anos atrás, atribuíram a mudança de atitude ao aparecimento do sindicato. Um dos dirigentes sindicais em Mundo Novo conta como davam no passado toda a espécie de assistência médica e que com "a fundação do sindicato, isto ficou ainda uns oito meses, depois desapareceu".

Pelo fato do operário recorrer ao sindicato, as obrigações tradicionais de proteção do patrão ao empregado e a lealdade deste para com aquele, tornam-se cada vez mais fracas. Não é de estranhar, pois, que a organização trabalhista esteja procurando assumir o papel paternalista do empregador. $\mathrm{O}$ presidente do sindicato de Mundo Novo considera os "benefícios" auferidos pelos operários e oferecidos pela organização sindical (assistência médica e remédios mais baratos), como o motivo principal pelo qual os operários tornam-se associados. É importante notar, também, a concessão de empréstimos e auxílios pecuniários pelo sindicato, tanto de uma cidade como de outra. Nas atas das reuniões da diretoria do sindicato de Mundo Novo, há várias vezes menção de pedidos de auxílio para compra de remédios, por parte de seus dirigentes e em Sobrado, onde o sindicato sofre maior pressão dos industriais, é ainda maior a preocupação em compensar os "direitos" perdidos pelo operário na fábrica.

Dessa análise concluímos que, embora continuem sendo seguidos os padrões tradicionais que unem empregados e empregadores, tende a aumentar o contato entre eles que se dá por intermédio do sindicato, na proporção que os esforços das empresas para elevação da produtividade e diminuição do custo de mão-de-obra produzem a dissolução das relações industriais tradicionais. Quando o empregado sente que o patrão não cumpre mais as suas obrigações de cuidar pelo seu bem-estar e quando, pelas razões apontadas atrás, deixa de ser atendido pelos mestres, aumenta o número de descontentes. O sindicato surge então como solução para o operário, quando, por um ou outro motivo, não mais atuam as relações tradicionais entre empregado e empregador. Quando contínuos pedidos dos operários aos mestres e contramestres - pessoas não tão ligadas como antes às obrigações e aos sentimentos comunais, ou pessoas sujeitas agora à desusada pressão para elevação de produtividade - não dão resultado, assume o sindicato, então, o papel de intermediário.

O processo é acumulativo. Num primeiro momento, a dinâmica da situação leva a uma quebra, cada vez maior, das relações tradicionais, promove um crescente distanciamento entre patrões e empregados e coloca o sindicato como instrumento rotineiro de contato entre operários e empregadores. Se a motivação profunda para os empregados participarem do sindicato e se utilizarem dos seus serviços, reside no afastamento ocorrido nas relações entre operários e patrões - ocasionado, por sua vez, pela própria natureza da organização industrial que se desenvolve - aquela participação e utilização, por seu lado, provocam distanciamento cada vez maior entre os dois grupos. Num segundo momento, representado grosso modo pelas fábricas de Mundo Novo, embora os empresários não sejam mais tão intolerantes com o sindicato, as relações industriais são já mais impessoais e a permanência da causa apontada (a maior concorrência do mercado) resulta no estabelecimento de relações rotineiras, do empregador com o empregado, através da organização trabalhista. 


\section{Capítulo V}

\section{Sistema industrial e estratificação social}

\section{Delimitação do tema}

Tratarei aqui dos efeitos do sistema industrial e de suas alterações, sobre a estratificação social. Uso a expressão "alterações do sistema industrial" em sentido amplo, para indicar não só mudanças tecnológicas, como as de estrutura econômica, tais como crescimento das empresas, modificações da estrutura do mercado etc. $\mathrm{O}$ assunto é vasto e necessário se torna limitá-lo no tempo e no espaço. Na primeira parte da exposição, considerarei apenas as mudanças mais recentes do sistema industrial, as quais se vêm intensificando desde, aproximadamente, o último quartel do século passado. Por outro lado, embora haja aspectos dos fenômenos em questão, com validade mais geral, focalizarei os setores industrialmente mais adiantados da sociedade ocidental. $\mathrm{Na}$ segunda parte, farei breve exame de alguns dos efeitos do desenvolvimento industrial sobre a estratificação social do nosso país.

Não tenho a intenção de examinar exaustivamente o problema; limitarme-ei a observações gerais sobre determinadas camadas da estratificação.

\section{Conceituação}

Poucas áreas da sociologia apresentam se tão confusas de pontos de vista como a da estratificação social. Indica-o a diversidade de termos encontrados na literatura especializada - casta, estamento, classe social, grupos de status, classes políticas, grupos sócio-econômicos etc. Embora isto decorra, em parte pelo menos, de confusão terminológica e teórica, par a par com diferenças de posição política, é provável, como sugere T. H. Marshall ${ }^{1}$, que reflita também a complexidade dos fatos a explicar. Não é

1 "General Survey of Changes in Social Stratification in the Twentieth Century", Transactions of the Third World Congress of Sociology, vol. III, Londres: International necessário mencionar toda a variedade de sistemas de estratificação encontrados nas sociedades atuais e nas do passado. Basta apontar para a natureza multidimensional da estratificação da sociedade ocidental moderna (Marshall pensa mesmo que o caráter multidimensional desta estrutura da nossa sociedade se vai progressivamente acentuando) ${ }^{2}$ e atentar para o fato de estar a mesma em fluxo continuo. Em artigo recente ${ }^{3}$, Nelson Foote, sociólogo americano, chega a empregar expressões como desestratificação e reestratificação. Para salientar este ponto de vista dinâmico, poderíamos denominar o nosso tema: aspectos da desestratificação e reestratificação da sociedade sob o impacto da mudança econômica.

Antes, porém, é necessário definir os termos a utilizar, não só devido à imprecisão dos mesmos na literatura sociológica, como também, porque, sendo a estratificação fenômeno multidimensional, se devem indicar os aspectos de interesse no momento. Um número crescente de sociólogos se tem utilizado das categorias empregadas por Max Weber - classe, status e poder ${ }^{4}$ - que indicam respectivamente as dimensões econômica, social e política do fenômeno da estratificação social. Nesta exposição, é de menor importância a dimensão poder ${ }^{5}$, e, por isso, discutirei, principalmente, as outras duas, isto é, classe e status.

O tratamento dado por Weber à estratificação social é essencialmente analítico. Classe e status não fazem parte de estruturas concretas que

Sociological Association, 1956, p. 2.

${ }^{2}$ Idem, p. 3-4.

${ }^{3}$ Nelson N. Foote, "Desestratification and Restratification: An Editorial Forewold", The American Journal of Sociology, vol. 58, nº 4 (janeiro de 1953), p. 325-326. Nestas páginas de introdução aos artigos deste número da revista The American Journal of Sociology, dedicados ao estudo da estratificação social, Foote mostra a necessidade, devido à rapidez da mudança social contemporânea, de análises da estratificação social que focalizem o processo de sua transformação.

4 "Class, Status, Party" , From Max Weber: Essays in Sociology, Tradução, notas e introdução de H. H. Gerth e C. Wright Mills, Londres: Kegan Paul, Trench, Trubner \& Co., Ltd., 1947, p. 180-195.

${ }^{5} \mathrm{O}$ estudo da "classe dominante" exemplifica o tipo de problema referente à dimensão poder da estratificação social. Ver, por exemplo, Gaetano Mosca, The Ruling Class (Elementi di Scienza Política), tradução inglesa de Hannah D. Kahn, Nova Iorque: McGraw-Hill Book Co., Inc., 1939. Marshall formula interessantes hipóteses sobre as condições conducentes à cristalização de uma classe dominante. Op. cit., p. 10. 
existam independentemente. São componentes causais do fenômeno da desigualdade social. $\mathrm{O}$ fato central a ser explicado é a distribuição desigual de oportunidades devida (Lebenschancen) entre os membros da sociedade, isto é, a probabilidade característica de aquisição de certos bens, do gozo de certas condições externas de vida e de experiência de determinadas satisfações e frustrações. Para Weber, tais oportunidades de vida não têm apenas uma única causa. A situação de classe e a posição na hierarquia de status são dois dos componentes causais das oportunidades de vida dos membros da sociedade.

A situação de classe de uma pessoa é, em última análise, a sua posição no mercado ${ }^{6}$ : ter ou não bens, e o tipo de bens ou de serviços, que se oferecem no mercado, são as categorias básicas na determinação da situação de classe. As oportunidades de vida decorrem não só da classe, como também da posição do indivíduo em uma hierarquia de status, isto é, em uma ordem segundo a qual o prestígio social se acha desigualmente distribuído pelos membros da sociedade ${ }^{7}$. As pessoas, que se encontram na mesma posição, nesta hierarquia, constituem um grupo de status; este tem, segundo Weber, o caráter de comunidade e caracteriza-se por um estilo de vida ${ }^{8}$. Status e classe operam conjuntamente para explicar um sistema de estratificação.

Desta breve exposição, vê-se que a análise do problema, por Weber, se situa claramente na herança intelectual marxista. Há, entretanto, diferenças capitais entre as duas interpretações do fenômeno, que precisam ser apontadas e que servirão para esclarecer melhor o ponto de vista aqui adotado.

${ }^{6}$ De forma mais rigorosa, Weber define a situação de classe como "a probabilidade característica de aquisição de certos bens, de gozo de certas condições externas de vida e de experiência de certas satisfações e frustrações pessoais, na medida em que essa probabilidade for determinada pela quantidade e espécie de poder, ou pela sua ausência, de probabilidade for determinada pela quantidade e espécie de poder, ou pela sua ausência, de
disposição de bens ou capacidades, para a obtenção de renda numa dada ordem econômica". Op. cit., p. 181

Escreve Weber sobre as bases da hierarquia de status: A consideração social "pode estar ligada a qualquer característica, que seja compartilhada por uma pluralidade de pessoas, e, é claro, pode estar associada à situação de classe...” E mais adiante: A estimação social do status "não precisa, necessariamente, estar ligada à situação de classe. Pelo contrário, regra geral, ela se opõe nitidamente às pretensões, puras e simples, da propriedade". Op. cit., p. 187.

As classes, pelo contrário, "não são comunidades; constituem apenas bases possíveis, e freqüentes, da ação comunal”. Op. cit., p. 187.
Tanto Marx como Weber vêem a origem das classes nas condições econômicas, mas o segundo salienta o mercado, ao invés das relações de produção e, portanto, liga o fenômeno a uma situação histórica. Uma sociedade em que as relações estão baseadas apenas em status e parentesco (como as descritas por Maine) não pode ter classes. O aparecimento da moderna estrutura de classes está inextricavelmente ligado à evolução histórica do mercado - processo analisado magistralmente por Karl Polanyi ${ }^{9}$. Além disso, a concepção de Weber abre caminho para uma análise mais acurada das situações de classe, embora, como Marx, considere básica a divisão entre os proprietários e os que oferecem no mercado apenas a força do seu trabalho. Consoante a forma de propriedade e a natureza do trabalho com que se apresentam no mercado, as pessoas gozam de distintas oportunidades de vida. Segundo Marx, o desenvolvimento do capitalismo industrial concorre para uma simplificação progressiva do esquema de classes, tendendo estas a se reduzirem a duas: de um lado, a dos capitalistas, cada vez mais poderosos e, de outro, as massas proletárias, cada vez mais pobres. Marx reconhecia a existência de outras classes, remanescentes do feudalismo ou pertencentes a setores secundários do sistema capitalista, tendendo umas e outras a serem absorvidas pelos dois grandes contendores - capitalistas e proletários ${ }^{10}$. A análise de Weber, pelo contrário, adapta-se perfeitamente à possibilidade de multiplicação das classes, oriundas da crescente diferenciação da estrutura do mercado. É neste sentido que procurarei, mais adiante levar a discussão do tema deste trabalho.

${ }^{9}$ The Great Transformation, Nova Iorque: Farrar \& Rinehart, 1944.

10 "Classe" e "luta de classe", os dois conceitos básicos da concepção marxista da história, não foram tratados por Marx sistematicamente em nenhuma parte de sua obra. O capítulo final do terceiro volume, póstumo, de seu livro - O Capital é um inicio de tal análise, que ficou, entretanto, inacabada (Capital, vol. III: The Process of Capitalist Production as a Whole, organizado por Frederick Engels, tradução inglesa de Ernest Untermann, Chicago: Charles H. Kerr \& Company, 1909, p. 1031-1032).

Precisamos, para compreender a sua concepção de classe social, analisar o uso que faz deste conceito nas suas obras históricas. Ver as seguintes análises do pensamento de Marx neste ponto: Nikolai Bukharin, "The Classes and the Class Struggle", Historical Materialism: A System of Sociology, Nova Iorque: 1925, p. 276-311; Reinhard Bendix e Seymour Martin Lipset, "Karl Marx's Theory of Social Classes", in Class, Status and Power: A Reader in Social Stratification, Glencoe, Ill.: The Free Press, 1953, p. 26-35; e G. D. H. Cole, Studies in Class Structure, Londres: Routledge and Kegan Paul, 1955, p. 10-25. 
A existência de uma classe não implica, necessariamente, na presença de consciência de classe ou em ação conjunta. A distinção traçada neste ponto por Weber é análoga à de Marx, entre classe em si (an sich) - um agregado de pessoas mantendo determinadas relações de produção, mas ainda não conscientes deste fato - e classe para si (für sich) - uma classe plenamente consciente da sua posição e papel social ${ }^{11}$. Entretanto, a relação entre os dois fenômenos é, para Marx, necessária e inevitável, resultando, com o tempo, da posição comum de classe, consciência dos interesses comuns e uma psicologia e ideologia específicas. Weber, por seu lado, coloca deliberadamente, como problema, o estudo das condições em que a ação de classe realmente se desenvolve quando afirma que o seu aparecimento e sua modalidade - societal (luta de classes, por exemplo) ou comunal $^{12}$ - não são de modo algum fenômeno universal. Na maioria das vezes, acrescenta, emergem apenas reações similares, individuais, não coletivas, no sentido daqueles interesses que mais se coadunam com a situação comum de classe. Enumera as condições determinantes do aparecimento ou não de ação conjunta, a partir de uma situação comum de classe: (a) condições culturais gerais (estou aqui seguindo praticamente as suas palavras), principalmente condições intelectuais; (b) o grau de diferenciação desenvolvida entre as situações de classe; e (c) até que ponto são percebidas, pelos membros da sociedade, as conexões entre a desigualdade social e a sua causa nas situações de classe ${ }^{13}$. É surpreendente constatar quão pouca pesquisa se tem feito neste campo. Uma linha óbvia de investigação, aponte-se de passagem, está no estudo comparativo do

${ }^{11}$ Ver os estudos citados na nota anterior, principalmente o de Bukharin.

${ }^{12}$ Ação comunal, no conceito de Weber, é a ação orientada pelo sentimento de comunidade dos membros do grupo; e ação societal, por outro lado, decorre do ajustamento racional de seus interesses. Op. cit., p. 183.

${ }^{13}$ Uma análise dos estudos históricos de Marx revela as determinantes que, segundo ele, facilitam o desenvolvimento de crenças e ações comuns por parte dos membros de uma classe (pessoas na mesma posição no processo de produção). Bendix e Lipset, depois de tal exame, concluem: "Dessa forma, a organização da producão constitui a base necessária, mas não suficiente, da existência de classes sociais. Constantes conflitos referentes às recompensas econômicas, fácil comunicação de idéias entre os membros da classe, aparecimento de consciência de classe, e crescente descontentamento com a exploração... são estas as condições que auxiliam a superação de diferenças e conflitos individuais e grupais, dentro de uma mesma classe e tornam-se responsáveis pela sua constituição em classe política autoconsciente”. Op. cit., p. 30. conflito industrial, nas várias categorias econômicas e profissionais, nos diversos países ${ }^{14}$.

Uma diferença crucial entre as duas análises do problema da estratificação é que, para Weber, ao contrário de Marx, a estratificação não tem apenas uma dimensão econômica; resulta também de uma hierarquia de status, fenômeno social no sentido restrito do termo. A importância deste ponto de vista tornar-se-á mais clara no decorrer desta exposição.

\section{Influência das mudanças recentes do sistema industrial na estratificação da sociedade ocidental}

São estes - classe e status - os conceitos principais utilizados neste trabalho. É claro que, considerando a natureza do problema - os efeitos das alterações recentes da estrutura industrial sobre a estratificação da nossa sociedade - a ênfase deverá cair no fenômeno classe, no sentido de Weber e o fator status será tratado em plano secundário, como elemento modificador da situação.

Antes de mais nada, devo mencionar a paucidade de pesquisas de campo que tratem do nosso problema; para bem situá-las, creio, deve-se lançar mão da análise histórica e de estatísticas ocupacionais.

Em artigo recente ${ }^{15}$, Cole mostra a constante dinâmica da estrutura de classes da Europa ocidental, com as sucessivas mudanças tecnológicas da revolução industrial. A primeira fase é a que se tem em mente ao usar a

\footnotetext{
${ }^{14}$ Escreve Marshall: "Para encontrarmos o que se conhece sobre a dinâmica das classes (no sentido weberiano restrito), precisamos atentar para as pesquisas no campo das relações industriais, do sindicalismo e das bases do poder na esfera econômica. Estes estudos são frequentemente micro-cósmicos (sic) e não concebidos primariamente como contribuições para o estudo da estratificação social”. Op. cit., p. 6. As pesquisas naquelas áreas, para serem mais significativas, deveriam ser comparativas e formuladas em relação a problemas de estratificação social. O trabalho de Kerr e Siegel pode ser citado como um exemplo nessa direção. Ver Clark Kerr e Abraham Siegel, "The Interindustry Propensity to Strike - An International Comparison”, in Arthur Kornhauser, Robert Dubin e Arthur M. Ross (ed.). Industrial Conflict, Nova Iorque: McGraw-Hill Book Co., Inc., 1954, p. 189-212.

${ }^{15}$ G. D. H. Cole, "The Influence of Technological Changes on the Development of Class structure in Western Europe", op. cit., p. 26-42.
} 
expressão "revolução industrial"; é o desenvolvimento do sistema fabril na indústria têxtil, no fim do século XVIII e começo do século XIX e as revoluções quase contemporâneas na mineração e metalurgia. A situação econômica do proletariado que surgiu não era, talvez, pior do que a dos trabalhadores do período do doméstico (putting-out); aquele proletariado era, porém, mais facilmente notado: achava-se aglomerado nas cidades, em péssimas condições urbanas, criadas pela própria revolução industrial. Realmente, nessa fase parecia que a profecia de Marx iria concretizar-se. O crescimento rápido das ferrovias, na meta e do século, a aplicação de métodos científicos à produção mecânica e o desenvolvimento do sistema bancário e do investimento industrial, marcam a segunda fase consoante Cole. Novos ofícios baseados na tecnologia da máquina, são continuamente criados e surge uma classe de operários qualificados, claramente diferenciada da massa não-qualificada, em grande parte constituída de recentes migrantes rurais. $\mathrm{O}$ sindicalismo que ganha força e estabilidade na época é um sindicalismo de operários qualificados, organizados de acordo com suas profissões. A massa operária não qualificada fica à margem do movimento trabalhista.

As duas fases mais recentes da análise de Cole são as que têm particular interesse para nós. Cria-se com elas o mundo industrial moderno, iniciado nas décadas finais do século XIX, através das transformações tecnológicas; é a época da eletricidade e do motor a explosão, da aplicação extensiva da química e, depois da física moderna, no campo da produção. Suas repercussões são de tal monta, que merecem de certos autores, entre os quais Georges Friedmann, a denominação de, segunda revolução industrial

${ }^{16}$. É todo o sistema industrial - empresas e estruturas de mercado - que se modifica.

"A grave depressão que se prolongou por mais de vinte anos, de 1873 a 1895", escreve Friedmann, "marca; definitivamente, o declínio do liberalismo econômico e o fim de uma época ainda dominada pela livre concorrência, pelo livre-cambismo e pela fé na coincidência "harmoniosa"

${ }^{16}$ Georges Friedmann, Problèmes humains du machinisme industriel, edição revista e aumentada, Paris, Librairie Gallimard, 1946, p. 13-25. Um livro recente de H. Pasdermadjan, La deuxième révolution industrielle (Paris: Presses Universitaires de France, 1959), examina a segunda revolução industrial nos seus aspectos tecnológicos, de organização e administração das empresas, e de processo de distribuição; dá, porém, muito menos atenção às suas conseqüências sociais e econômicas mais amplas. do interesse individual e do coletivo" ${ }^{17}$. Principia, então, uma concentração de propriedade industrial sem precedentes. Propriedade e controle da empresa separam-se; surge a grande sociedade anônima dos dias de hoje. É a época dos Rockfeller, dos Carnegie, dos Morgans, dos Krupp. São os trustes, os pools e os corners que se formam. A concorrência passa a ser entre os poderosos grupos nacionais ou internacionais. Ao mesmo tempo, aparece o protecionismo, os mercados nacionais abrigando-se atrás das muralhas alfandegárias.

Simultaneamente às transformações de estrutura econômica operam-se outras na organização das empresas. A racionalização do trabalho, ao se findar o século XIX ${ }^{18}$, exemplificada pelo taylorismo e, mais tarde, a introdução de formas de produção em massa, têm o mesmo sentido. Resultam na segmentação progressiva do trabalho industrial, até a sua quase completa decomposição em operações elementares, unidas pela linha de produção. Ao lado de máquinas cada vez mais especializadas, coloca-se uma mão-de-obra cada vez menos qualificada, não sendo os operários mais do que "cuidadores de máquinas", que, com pouco treino, podem ser transferidos de um serviço para outro: seu trabalho exige apenas destreza e não qualificação verdadeira. Esta mudança realmente consistiu na separação, nos trabalhos industriais, da função de planejamento da de execução. Ao mesmo tempo em que os trabalhadores manuais se nivelavam num mesmo plano de semiqualificação, criava-se um exército de supervisores, de toda ordem de técnicos, de administradores e empregados de escritório. "A consequiência - estou citando Cole - foi uma diferenciação muito maior nas classes dos empregados, e uma perda de nitidez da divisão entre trabalhadores manuais (wage-earners) e empregados de escritório (salary-earners) e, portanto, entre os "trabalhadores" e a "classe média inferior" ${ }^{19}$,

\footnotetext{
${ }^{17}$ Friedmann, op. cit., p. 19

${ }^{18}$ Estou me referindo à fase do movimento de racionalização do trabalho que começa com Taylor, Gilbreth, Gantt etc. Entretanto, é claro, não quero dizer que a racionalização do trabalho se iniciou nessa época. Em qualquer sentido legitimo da expressão, o processo de racionalização do trabalho coincide com o próprio desenvolvimento do capitalismo moderno, desde a sua origem. Ver, por exemplo, Max Weber, "The Development of Industrial Technique", General Economic History, tradução inglesa de Frank H. Knight, Londres: George Allen \& Unwin, sem data, p. 302-314.

${ }^{19}$ Op. cit., p. 39.
} 
São muitas as mudanças sociais impelidas pela segunda revolução industrial e que são pertinentes à nova estrutura de classes. Podem-se mencionar a difusão da propriedade através da posse de ações, o crescimento do setor terciário - comércio, finanças, administração pública, o aumento percentual dos profissionais liberais e a profissionalização de um número crescente de ocupações. Pretendo tecer comentários apenas sobre os dois desenvolvimentos já mencionados: a crescente importância das "novas classes médias" e o operariado semiqualificado.

A importância cada vez maior do trabalhador industrial semiqualificado pode ser acompanhada perfeitamente nas Estatísticas ocupacionais. Nos Estados Unidos, por exemplo, de 1910 para cá, nota-se uma diminuição dos operários qualificados (skilled) e não-qualificados (unskilled) em relação aos semiqualificados (semi-skilled). O processo é geral nos países industriais do mundo ocidental. No que se refere ao operário característico do sistema industrial hodierno, pode-se falar em degradação, empregando-se o termo em seu sentido etimológico - pois há perda de qualificação com o progresso tecnológico - e em nivelamento, pois a uma variedade de ofícios Se substitui um operariado mais homogêneo. Justifica-se falar, segundo as categorias weberianas, em aparecimento de nova situação de mercado? Creio que sim. O operário semiqualificado é o machine-tender, o cuidador de máquinas, mero apêndice do equipamento técnico da indústria. Não tem propriamente ofício, pode ser treinado para operar máquina semi-automática ou para trabalhar junto à linha de fabricação em série, em questão de semanas. A especificidade da sua situação de classe ${ }^{20}$, em relação à dos operários oficiais, consiste no fato de ser facilmente substituível. A transformação da situação de classe fez-se sem resultar, de imediato, em consciência e ação de classe. Percebe-se isto, atentando-se para as formas de organização

\footnotetext{
${ }^{20}$ Quero apenas sugerir o aparecimento de uma classe de operários semiqualificados, distinta de outras classes de trabalhadores manuais. Uma das principais dificuldades, a meu ver, da aplicação das categorias weberianas de "situação de classe" e "classe" reside na própria determinação da probabilidade característica de certas oportunidades de vida. Até que ponto a delimitação das diversas situações de classe depende das oportunidades dia vida escolhidas para estudo e, portanto, resulta apenas numa "classificação" do pesquisador? A análise deste ponto é uma das possibilidades de aprofundamento teórico do problema de classes, o qual ultrapassa os limites deste estudo.
}

sindical que surgem na história do movimento trabalhista. As primeiras organizações de trabalhadores que aparecem na Inglaterra, França, e Estados Unidos, são sindicatos de operários qualificados. Na Inglaterra, ao descrever os sindicatos dos meados do século XIX, fala-se numa aristocracy of labour. São os sindicatos organizados segundo linhas ocupacionais, craft-unions, como são denominados nos países de língua inglesa. O novo tipo de trabalhador - nas grandes sociedades anônimas - $\mathrm{o}$ semiqualificado, o qual opera máquinas semi-automáticas ou automáticas e pode ser substituído por outro operador de máquinas diferentes, de momento para outro, torna inoperante o velho tipo de sindicato - segundo linhas ocupacionais. Este podia subsistir somente nos casos em que subsistia a qualificação profissional. Para os "torneiros" das linhas de produção de várias empresas, por exemplo, não faz sentido a sindicalização à parte dos outros trabalhadores do mesmo ramo industrial. Com baixa qualificação, substituíveis, qualquer ação conjunta desse grupo isolado dos demais será pueril. Entretanto, um novo tipo de sindicato, reunindo todos os operários de um mesmo ramo industrial, quaisquer que sejam suas "ocupações", tardou a se formar. O caso americano é marcante. Embora a nova situação de classe tivesse surgido bem antes da primeira guerra mundial, a formação das grandes industrial unions daquele país, somente ocorreu na década de 30, sob o impacto da depressão econômica. É interessante notar que, a partir daí, o sindicalismo americano ganhou força.

Faltam pesquisas, estudando pormenorizadamente tais processos histórico-sociais. A análise da greve nas indústrias de sapato, de uma pequena cidade da Nova Inglaterra, realizada por Warner e seus colaboradores, é uma entre poucas que pode ilustrar o que foi dito anteriormente ${ }^{21}$. Os operários das indústrias de Yankee City não eram sindicalizados e nunca haviam participado de greve alguma. Empregadores e líderes trabalhistas eram unânimes em afirmar que os operários das indústrias da comunidade jamais fariam greve. Entretanto, no período mais grave da depressão, eles entraram em greve e todas as fábricas da cidade paralisaram suas atividades. O movimento durou um mês e, nesse tempo, os

${ }^{21}$ William Lloyd Warner e J. O. Low, The Social System of the Modern Factory: A Social Analysis, New Haven: Yale University Press, 1947; ver também W. Lloyd Warner e J. O. Low, "The Factory in the Community", in William F. Whyte (ed.), Industry and Society, Nova Iorque: McGraw-Hill Book Co., 194G, p. 21-45. 
operários organizaram um sindicato: os empregadores foram totalmente derrotados. Warner, ao analisar as causas profundas da sindicalização e da greve, concluiu que estas eram decorrentes das modificações históricas do sistema industrial. Em primeiro lugar, Warner aponta, como fator causal, a quebra da hierarquia de ofícios qualificados. Anteriormente, a divisão de trabalho da indústria, de sapatos era constituída por uma série de ofícios que exigiam graus de qualificação diversos. Tais ofícios formavam, na realidade, uma hierarquia de prestígio e idade, ligada à qualificação crescente. Ao ficar mais velho, o. trabalhador podia esperar passar para ofícios mais qualificados, de maior prestígio e melhor remunerados. Com a mecanização, cada ofício foi subdividido em vários serviços, exigindo baixa qualificação e as máquinas passaram a executar a maioria das operações necessárias. A hierarquia de ofícios qualificados transformara-se numa camada horizontal de funções igualmente pouco qualificadas.

A segunda causa é a perda do controle das indústrias pela comunidade. As fábricas antes pertenciam a indústrias locais; com a expansão das empresas, passaram a fazer parte de estruturas industriais muito mais amplas, com escritórios centrais nas grandes capitais e fábricas noutras cidades. Warner mostra que, enquanto as fábricas eram de propriedade local, os industriais eram líderes da comunidade, membros da "classe alta" e a sua administração refletia o controle informal exercido pelas atitudes e tradições da comunidade. "Havia sentimentos de vizinhança e amizade entre o diretor e o operário. e responsabilidades mútuas, um em relação ao outro, e à comunidade, que iam muito além dos acordos formais entre empregador e empregado,"22. A expansão da estrutura industrial destruiu tais relações pessoais, lealdades e obrigações. As decisões passaram a ser feitas fora da comunidade, sem levar em consideração as suas necessidades e interesses específicos. A teia de relações, que tornavam os industriais líderes da comunidade, foi substituída por uma relação. "puramente econômica de empregador e empregado" 23 .

Em suma, as raízes da greve e da sindicalização encontradas por Warner estão nas transformações que ultrapassam de muito Yankee City e que constituem a segunda revolução industrial. Este estudo mostra como os

\footnotetext{
22 "The Factory in the Community", loc, cit., p. 35
}

${ }^{23}$ Idem, p. 40. fenômenos de classe e status podem estar inter-relacionados ${ }^{24}$. $\mathrm{Na}$ época em que as indústrias ainda eram locais e a antiga divisão de trabalho ainda estava intacta, a dimensão básica da estratificação era a de classes; porém, sobre esta estrutura havia, claramente superposta, uma hierarquia de status, com os fenômenos característicos de estilo de vida, prestígio tradicional etc. As mudanças tecnológicas e econômicas modificaram as situações básicas de classe e destruíram a hierarquia de status que, sobre as mesmas, se havia desenvolvido. A redefinição da própria posição, pelos operários, segundo interesses de classe, e o aparecimento de ação conjunta, foram causados, é importante salientar, tanto pelas ansiedades provoca das pela quebra da hierarquia de status, quanto pela própria mudança da situação de mercado.

Todavia, mostrar a inter-relação apenas num caso concreto, entre os fenômenos de classe e de status, não é suficiente; é necessário analisar, também, qual dos dois constitui a estrutura básica. Para a explicação de fatos, tais como sindicalização e greve, esta parece ser a de classe, tendo o fenômeno status caráter derivado.

Para maior compreensão da estratificação social da sociedade ocidental moderna e da sua dinâmica, é importante fazer a análise históricosocial de mais variados casos do que os até agora estudados. Como já disse, o campo que me parece mais promissor para pesquisas deste problema é o do estudo comparativo do movimento trabalhista e das relações de conflito industrial, considerando-se sempre as condições concretas de mercado, a sua dinâmica e peculiaridades, bem como as condições sociais em que tais fenômenos ocorrem ${ }^{25}$.

O outro aspecto da segunda revolução industrial, que quero comentar rapidamente, é o da burocratização ${ }^{26}$ da empresa industrial e seus efeitos sobre o sistema de classes. Dois dos traços - interdependentes - da segunda revolução industrial são responsáveis pela burocratização das empresas: a formação das gigantescas sociedades anônimas hodiernas e o movimento de racionalização do trabalho. Como já disse, a "taylorização" das empresas e a introdução dos métodos de produção em massa, significaram uma

${ }^{24}$ Esta interpretação difere da de Warner, cuja conceituação de classe social não distingue as dimensões classe e status da estratificação social.

${ }^{25}$ Ver nota 14

${ }^{26}$ Emprego o termo burocratização no sentido dado por Weber. Op. cit., p. 196-244. 
separação, mais completa e mais radical do que no passado, das funções de planejamento das de execução. Se, por um lado, devido a este processo, o operário semiqualificado se restringia a obedecer ordens e não decidia nem ao menos como executar o seu trabalho, por outro, criava uma, quantidade enorme de supervisores, técnicos de tempo e movimento, inspetores de qualidade, programadores de produção etc. Devo observar, entre parênteses, que a "automação", hoje tão em voga nas discussões de problemas industriais, representa, neste ponto, a continuação dessa tendência. Um aspecto da burocratização, portanto, é o aumento da proporção do pessoal administrativo em relação à mão-de-obra diretamente aplicada na produção. Documenta-o Reinhard Bendix, em um estudo comparativo da burocratização da indústria nos Estados Unidos, França, Alemanha, Inglaterra e Suécia, com relação a todos estes países ${ }^{27}$.

Não é meu propósito discutir aqui, exaustivamente, a posição desses grupos, numericamente cada vez mais importantes, no sistema de estratificação. Não que isto não tenha significado fundamental para a compreensão do mesmo, como o teria, também, a análise da dinâmica de sua posição, é que este assunto ultrapassaria, de muito, os objetivos que fixei para esta exposição, quais sejam o de mostrar a contínua dinâmica da estratificação social, resultante da mudança da estrutura econômica, inerente à sociedade industrial, e de ilustrar alguns dos desenvolvimentos mais recentes do sistema de estratificação. É interessante, porém, mostrar a variedade de interpretações do papel e da dinâmica das chamadas "novas classes médias" ${ }^{28}$. Há quem julgue que estas se transformarão, com o tempo, numa classe politicamente independente, destinada a ser a classe dominante do futuro. Outra interpretação é a que acentua a importância dessas classes intermediárias, entre o Capital e o Trabalho, como "amortecedores" de conflitos sociais e estabilizadores da ordem social. Segundo outro ponto de vista, tais camadas são objeto do processo previsto pelo esquema marxista; os caracteres que as distinguem dos trabalhadores

27 "The Bureaucratization of Economic Enterprises", Work and Authority in Industry: Ideologies of Management in the Course of Industrialization, Nova Iorque: John Wiley \& Sons, Inc., 1956, p. 198-253.

${ }^{28}$ Ver C. Wright Mills, White-Collar: The American Middle Classes, Nova Iorque:. Oxford University Press, 1953, p. 290-291. manuais (renda, educação, prestígio etc.) desaparecerão e, com o aumento da intensidade da luta de classes, serão amalgamadas pela classe proletária.

Não há escassez de estudos e interpretações na análise deste problema. Há necessidade, porém, de maior clareza teórica e maior cuidado metodológico. Como observa C. Wright Mills, as interpretações contraditórias propostas decorrem, em boa medida, de terem os estudiosos em mente setores diversos das "novas classes médias", definindo-as segundo grupos ocupacionais diferentes 29. Faz-se mister proceder a análises mais precisas destas camadas (uma das melhores é a de Mills: White Collar), que focalizem, para cada uma, separadamente, os componentes classe e status, as perspectivas e atitudes coletivas, a tendência para organizar-se (inclusive sindicalização) e o comportamento político.

Para terminar esta primeira parte da exposição, direi alguma coisa sobre status e o seu papel no sistema de estratificação da sociedade industrial. Vimos que, para a compreensão dos fenômenos em Yankee City, tanto status como classe precisam ser utilizados. Sugeri que status, em Yankee City, era o fator secundário e classe o primário e fundamental. Para fazer tal distinção entre o primário e o secundário, é necessário, entretanto, analisar o processo histórico-social, responsável pelo sistema de estratificação. A sugestão, que fiz, coaduna-se com as hipóteses levantadas por Marshall, em trabalho já citado ${ }^{30}$. Sugere o sociólogo inglês que, na Europa Ocidental, o atual sistema de status (remanescente da aristocracia) constitui herança dos estamentos do período feudal, anterior ao capitalismo, e estaria sofrendo gradual desgaste com a democratização da sociedade. A situação em países como os Estados Unidos, onde nunca houve estamentos, seria diversa. Os fenômenos de status formaram-se aí na medida em que as desigualdades sociais, baseadas em classes, se cristalizaram e se ligaram a valores culturais. Concordando-se com o contraste traçado na hipótese de Marshall, poderíamos acrescentar a sugestão de que, na Europa, par a par com o processo de desintegração dos remanescentes da antiga estrutura de status, ocorreu a formação de novas hierarquias de status, sempre que a mudança econômica diminuiu seu ritmo. Na Europa ou nos Estados Unidos, haveria fases de enfraquecimento das novas estruturas de status (que

${ }^{29}$ Idem, p. 291-292; Cole, “The Conception of the Middle Classes", op. cit., p. 78-79. ${ }^{30}$ Op. cit., p. 13-14. 
denominei de secundárias, por superpostas à estrutura de classes), nos períodos de recrudescimento da mudança tecnológica (caso dos processos analisados em Yankee City).

Para finalizar, resta mencionar um: fenômeno de estruturação em grupos de status, cuja persistência na sociedade industrial dificilmente poderia ser relegada a um segundo plano ou ser considerada como desenvolvimento secundário da estrutura de classes. Quero referir-me aos grupos étnicos e raciais. Evidente é a sua importância, como elemento modificador da estratificação da sociedade industrial, em países como os Estados Unidos. Qualquer que seja a sua classe, as oportunidades de vida de um americano são determinadas, em boa parte, pelo grupo racial a que pertence. Não obstante haver estudiosos ${ }^{31}$ que buscam uma causalidade econômica para a situação racial americana, a meu ver, tais análises são artificiais e não explicam os fatos. Grupo racial é, tanto como classe, um elemento necessário para explicar a desigualdade na sociedade americana. Pode-se colocar como problema até que ponto a dinâmica e as exigências do sistema industrial estão concorrendo para enfraquecer, ou pelo menos modificar, a situação racial. A política deliberada de aceitação de negros, adotada por sindicatos do norte do país, ilustra o tipo de fatos que devem ser analisados para a compreensão do problema.

\section{Algumas observações sobre industrialização e estratificação social no Brasil}

Ao considerar o problema no Brasil, é preciso acrescentar ainda outro aspecto da estratificação social, o que diz respeito à unidade da estrutura, pois o Brasil, como já foi dito muitas vezes, é, em certa medida, uma sociedade plural. Falar, portanto, de um único sistema de estratificação para as várias, partes do país é interpretação demasiado simplista. Isto não significa, necessariamente, que nelas existam sistemas de estratificação desligados uns dos outros. Determinar o modelo que melhor se ajuste à realidade brasileira é questão ainda não resolvida. Seja qual for, entretanto,

${ }^{31}$ Ver, por exemplo, Oliver Crowell Cox, Caste, Class \& Race: A Study in Social Dynamics. Nova Iorque: Doubleday \& Company, Inc., 1948, p. XXIX-XXXVIII. parece certo que classe e status têm importância e papel diversos nas várias partes componentes do sistema de estratificação social. É preciso, além disso, compreender a organização social, no seu dinamismo. O Brasil novo está crescendo à custa do Brasil arcaico ${ }^{32}$, tanto pela expansão das técnicas econômicas modernas, como pelos movimentos de migração interna.

Minha intenção é apenas apresentar uns poucos dados pertinentes à incorporação de contingentes rurais à classe operária. A questão tem, realmente, dois aspectos. Primeiro, a situação objetiva, a respeito da qual poderíamos indagar: quão estável é a mudança de posição dos operários de origem rural? Permanecem os rurícolas na condição de operários? O segundo aspecto, inter-relacionado evidentemente com o primeiro, é o de se saber até que ponto daquela mudança de posição resultou o aparecimento, entre os operários, de novas atitudes e normas coletivas, assim como de solidariedade e ação conjunta.

Não pretendo propor soluções definitivas para tais problemas, mas simplesmente discutir, na base de duas pesquisas, algumas idéias a respeito.

O primeiro caso, que citarei, é o de uma pequena cidade industrial no interior do Brasil ${ }^{33}$, com uma população pouco superior a 10.000 habitantes. A principal fonte de trabalho aí existente é uma fábrica, com cerca de 1.000 operários, fundada em 1925. Os industriais pertencem a uma família tradicional, de grandes proprietários de terras, um destes clãs políticos, tão comuns no Brasil. O operariado provém, predominantemente, da zona rural circundante, impelido por alteração profunda na economia do campo, qual seja a substituição da agricultura pela pecuária, com a sua escassa mão-deobra. Um exame das relações industriais revela, porém, que elas conservam os mesmos padrões tradicionais que uniam o fazendeiro e seus prepostos aos colonos e camaradas. Lealdade e subordinação de um lado, e a obrigação moral de proteção, do outro, são normas transplantadas da

${ }^{32}$ Jacques Lambert, Le Brésil, Paris: Librairie Armand Colin, 1953, p. 64-82.

33 Pesquisa realizada em 1958, patrocinada pela Campanha Nacional de Erradicação do Analfabetismo, do Ministério da Educação e Cultura. A descrição que segue representa o resultado de um primeiro exame de dados, que ainda não estão completamente analisados. Ver o primeiro relato da pesquisa no trabalho do autor: "Relations industrielles dans deux communautés brésiliennes", Sociologie du Travail, 1961, n. ${ }^{\circ}$ 4, p. 330-344. (Tradução publicada neste livro às p. 135-151.). 
fazenda para a fábrica. Sendo os diretores, também, grandes proprietários rurais, a obtenção de emprego industrial significa, não raro, apenas a continuação de uma relação de dependência preexistente. A relação que liga o operário aos patrões não é simples relação contratual de emprego; é uma relação total: o patrão, além de empregador, é quem dá moradia, empresta dinheiro, aconselha e ajuda nas horas de dificuldades. A preocupação que tem pelo bem-estar do operário e sua família não visa, calculadamente, à obtenção de determinados fins; é expressão espontânea advinda da obrigação tradicional de membros da "classe alta" de cuidarem de seus dependentes.

O industrial, por sua vez, não exige - do operário somente aqueles deveres inerentes à função de simples empregado, pois este não tem deveres definidos e delimitados, a não ser o de lealdade. Votar em partido contrário ou recorrer ao sindicato são atos de deslealdade e razão suficiente para quebra da relação tradicional. O sistema de autoridade pode ser descrito, grosso modo, como hierarquia de relações pessoais e costumeiras. Os mestres são "homens de confiança" dos donos; estes "podem contar com eles" para serviços que exorbitam de muito de uma simples relação de emprego, estreita e nitidamente delimitada. Os mestres, por outro lado, gozam de toda a sorte de privilégios. Esta relação patrão-mestre tende a se repetir, ao passo que se desce na escala hierárquica.

Esta descrição peca por deixar de lado a dinâmica das relações. Não é difícil perceber a atuação de fatores de mudança, como, por exemplo, a necessidade de aumento de produtividade, imposta aos industriais pela concorrência de seus produtos no mercado nacional, a legislação trabalhista e o aparecimento do sindicato. Vejamos qual parece ser o processo de mudança que, por vários motivos, leva a um enfraquecimento das relações tradicionais. $\mathrm{O}$ acirramento da concorrência leva os empresários a procurar intensificar o ritmo de trabalho e a reduzir a assistência aos seus empregados. Empenham-se, por exemplo, em exercer pressões, sem base em estudos sistemáticos, para aumentar a eficiência, que sabem baixa. Os operários, por seu turno, vêem que trabalhando tanto ou mais, não ganham como antes. Os ressentimentos criados por estas circunstâncias tendem a ser canalizados para o sindicato e o presidente deste, como era de esperar, torna-se, na maioria das vezes, mero porta-voz: pede pelo empregado, mas com toda a cautela, para não desagradar "os patrões". Não obstante este fato, a procura do sindicato, pelo operário, é tomada como ruptura das relações tradicionais. O industrial, a partir deste momento, sente-se desobrigado de cuidar de seu empregado, podendo este até perder o emprego ou, pelo menos, na expressão local, "perder seus direitos na fábrica" (deixar de receber empréstimo, "vales" para médico etc.). Não é de admirar que somente operários estáveis pertençam à diretoria do sindicato. Desejo chamar a atenção para a circularidade do processo. Um enfraquecimento das relações tradicionais leva a um encadeamento de ações que têm por resultado final uma ruptura, ainda maior, das mesmas; há um distanciamento crescente entre patrões e empregados e o sindicato torna-se instrumento rotineiro de contato entre operários e empregadores.

Antes de sua vinda para a cidade, estes operários já estavam colocados numa situação de mercado; a estrutura de classes, porém, devido à sua estabilidade, tradicionalizou-se, com o conseqüente desenvolvimento de atitudes, estilos de vida e relações característicos de estruturação em grupos de status; as duas dimensões no caso coincidiam. Na fábrica, apesar de as situações de classes haverem se transformado, conservou-se a hierarquia de status tradicional. Com base na nova posição de classe, surge a ação conjunta - na realidade muito incipiente - segundo interesses comuns, somente quando aquela hierarquia de status é abalada.

Um outro estudo, o da mão-de-obra de origem rural de uma fábrica, na cidade de São Paulo ${ }^{34}$, ajudará a esclarecer o processo de formação da classe operária. Nesta empresa industrial cerca de dois terços dos operários semiqualificados das linhas de produção vieram da lavoura, ou de pequenas vilas do Brasil. Oriundos de um mundo rural tradicional, integraram-se na estrutura fria e impessoal da fábrica moderna, onde não existem condições para a permanência dos padrões e relações tradicionais. Nota-se, porém, a atuação de valores tradicionais, relativos ao trabalho, por exemplo, o da independência econômica, "trabalhar por conta própria". Desligados da estrutura social de origem, tendem a agir, para implementação desses

${ }^{34}$ Ver o meu artigo: "A Fixação do Operário de Origem Rural na Indústria. Um Estudo Preliminar”, Educação e Ciências Sociais, vol. II, n. ${ }^{\circ}$ 6, Ano 2 (novembro de 1957), p. 293 322. Os resultados completos desta pesquisa acham-se publicados no capítulo 12 do livro Mobilidade e Trabalho (por Bertram Hutchinson e outros), Rio de Janeiro: Centro Brasileiro de Pesquisas Educacionais, 1960, p. 360-440. Reimpresso neste livro às p. 16-86. 
valores, conforme os seus “interesses pessoais". Daí observar-se a pouca identificação destes trabalhadores de origem rural com a condição de operário. São constantes as mudanças de emprego, muitas das quais os levam, novamente, para a lavoura, ou, pelo menos, saindo da estrutura industrial, para o comércio ambulante ou outras formas de trabalho "por conta própria. Pode-se dizer, e tanto o seu comportamento como suas atitudes o demonstram, que se utilizam do emprego fabril, da legislação trabalhista e do sindicato (a fim de, por exemplo, receberem indenização por dispensa), para conseguirem estabelecer-se em ocupação independente.

Análise do comportamento destes operários, durante uma greve ocorrida em 1957, no ramo industrial a que pertencem, mostrou quão tênue era a sua solidariedade; esta baseava-se numa vaga hostilidade em relação aos patrões e o grupo solidário era apenas o de colegas de trabalho. Não se notaram, além do mais, entre eles, normas sociais relativas à conduta no trabalho, que, criadas no ambiente industrial, indicassem a existência de um grupo diferenciado.

Ao contrário dos trabalhadores da fábrica do interior, os de São Paulo acham-se numa fábrica em cuja estrutura não persistem relações tradicionais. A hostilidade aos patrões e a colocação das relações em termos de interesse são fatos mais evidentes. Tais atitudes e sentimentos, porém, não servem de base para participação em ação conjunta, quer independentemente, quer através do sindicato. Entre as determinantes desta situação, como procurei mostrar, está o fato de não permanecerem na condição de operário, resultante, ao mesmo tempo, da sua orientação psicológica para atividades independentes e da existência de alternativas econômicas na metrópole.

$\mathrm{Na}$ cidade do interior, ao contrário, formou-se um operariado de relativa estabilidade, decorrente das poucas possibilidades de outros empregos que não o fabril. A alternativa, na maioria dos casos, é a migração para outra comunidade. A ação operária é provavelmente facilitada, também, pelo fato de todos os associados do sindicato trabalharem na mesma empresa e estarem unidos por laços comunais, de parentesco e de vizinhança. Encontramos aí, portanto, maior identificação do operário com o sindicato e alguns exemplos de ação conjunta, embora tímida.
Mais estudos fazem-se necessários, antes que tenhamos uma compreensão da processo de formação da classe operária na Brasil. As pesquisas que mencionei focalizam os setores da classe que se estão formando à custa de migrantes rurais. Certamente há outros, nos centros mais industrializados, onde se acha mais adiantado aquele processo.

Creio haver ilustrado suficientemente a perene mudança da estratificação social da sociedade ocidental, sob a ação do dinamismo inerente ao seu sistema industrial. "Mudança", porém, é termo demasiadamente neutro para caracterizar a processo, e "estratificação", demasiadamente estático para indicar fenômenos que estão em fluxo; por isso, volto a salientar as desestratificações e reestratificações que ocorrem continuamente, com ritmos variados e, de tal forma, que se justapõem camadas, em vias de desaparecimento, baseadas em condições objetivas e subjetivas do passado, a outras ainda não completamente formadas.

Tal situação é especialmente patente em países como o Brasil onde uma estrutura arcaica começa a se transformar, devido à expansão da sistema industrial. O processo, aqui, apresenta aspectos que, provavelmente, se assemelham a situações criadas nas pequenas vilas industriais dos primórdios da industrialismo europeu. Mas não convém ir longe demais com o paralelo. Migrantes rurais vêm para um sistema industrial (e, portanto, colocam-se numa situação de classe) que muito difere das primeiras fábricas da Revolução Industrial do século XVIII.

Para entender a formação da classe operária no Brasil, (creio ser indispensável levar em conta esta "superposição de épocas" Na primeira parte deste trabalho, tratei do aparecimento, nos países mais industrializados, de novas situações de classe, tais como a do operariado semiqualificado e a das "novas classes médias". Tais fenômenos são tão importantes para se compreender a estratificação do Brasil industrial, como o processo, acima examinado, de assimilação de contingentes rurais ao seu proletariado. 